San Jose State University

SJSU ScholarWorks

Master's Theses

Master's Theses and Graduate Research

1990

\title{
Laramide basin subsidence and fluvial architecture of the Fort Union and Wasatch Formations, Southern Green River Basin, Wyoming
}

Philip L. Johnson

San Jose State University

Follow this and additional works at: https://scholarworks.sjsu.edu/etd_theses

\section{Recommended Citation}

Johnson, Philip L., "Laramide basin subsidence and fluvial architecture of the Fort Union and Wasatch Formations, Southern Green River Basin, Wyoming" (1990). Master's Theses. 56.

DOI: https://doi.org/10.31979/etd.m6sw-gqfq

https://scholarworks.sjsu.edu/etd_theses/56

This Thesis is brought to you for free and open access by the Master's Theses and Graduate Research at SJSU ScholarWorks. It has been accepted for inclusion in Master's Theses by an authorized administrator of SJSU ScholarWorks. For more information, please contact scholarworks@sjsu.edu. 


\section{INFORMATION TO USERS}

The most advanced technology has been used to photograph and reproduce this manuscript from the microfilm master. UMI films the text directly from the original or copy submitted. Thus, some thesis and dissertation copies are in typewriter face, while others may be from any type of computer printer.

The quality of this reproduction is dependent upon the quality of the copy submitted. Broken or indistinct print, colored or poor quality illustrations and photographs, print bleedthrough, substandard margins, and improper alignment can adversely affect reproduction.

In the unlikely event that the author did not send UMI a complete manuscript and there are missing pages, these will be noted. Also, if unauthorized copyright material had to be removed, a note will indicate the deletion.

Oversize materials (e.g., maps, drawings, charts) are reproduced by sectioning the original, beginning at the upper left-hand corner and continuing from left to right in equal sections with small overlaps. Each original is also photographed in one exposure and is included in reduced form at the back of the book.

Photographs included in the original manuscript have been reproduced xerographically in this copy. Higher quality 6" $\times$ 9" black and white photographic prints are available for any photographs or illustrations appearing in this copy for an additional charge. Contact UMI directly to order.

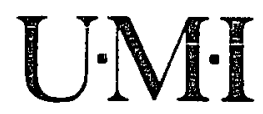


Order Number 1842718

Laramide basin subsidence and fluvial architecture of the Fort Union and Wasatch formations, southern Green River basin, Wyoming

Johnson, Philip Leigh, M.S.

San Jose State University, 1990 
NOTE TO USERS

THE ORIGINAL DOCUMENT RECEIVED BY U.M.I. CONTAINED PAGES WITH PHOTOGRAPHS WHICH MAY NOT REPRODUCE PROPERLY.

THIS REPRODUCTION IS THE BEST AVAILABLE COPY. 



\title{
LARAMIDE BASIN SUBSIDENCE AND FLUVIAL ARCHITECTURE OF THE FORT UNION AND WASATCH FORMATIONS, SOUTHERN GREEN RIVER BASIN, WYOMING
}

\author{
A Thesis \\ Presented to \\ The Faculty of the Department of Geology \\ San Jose State University \\ In Partial Fulfillment \\ of the Requirements for the Degree \\ Master of Science
}

By

Philip L. Johnson

December, 1990 
APPROVED FOR THE DEPARTMENT OF GEOLOGY
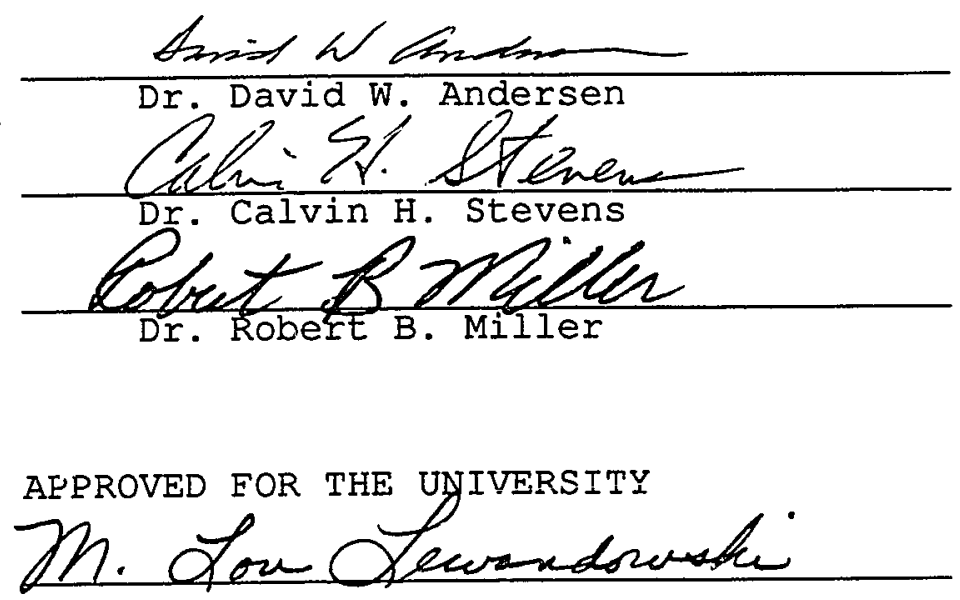


\section{ACKNOWLEDGMENTS}

I would like to express my appreciation to the members of my thesis commitee at San Jose State University. C. H. Stevens and R. B. Miller provided helpful comment on this work. Special thanks go to $D$. W. Andersen who suggested this study and provided much guidance and support both in the field and during preparation of this manuscript. I am indebted to him for introducing me to the geology of Wyoming.

I am also appreciative of the support given to me by M. A. Kirschbaum and R. D. Hettinger of the U. S. Geological Survey. I. Copeland and D. Fox provided technical assistance on the preparation of this manuscript.

Funding for this study came from WAAIME and the society of Archimedes at San Jose State University.

Finally, I would like to thank my family. My parents, Paul and Genevieve Johnson, provided the encouragement and financial support that allowed me to complete this work. Thanks go to my sister, Ciri Johnson, and brother, Christopher Johnson for their moral support during the months of field work. My cousin, Michael Albright, also provided assistance in the field. 
TABLE OF CONTENTS

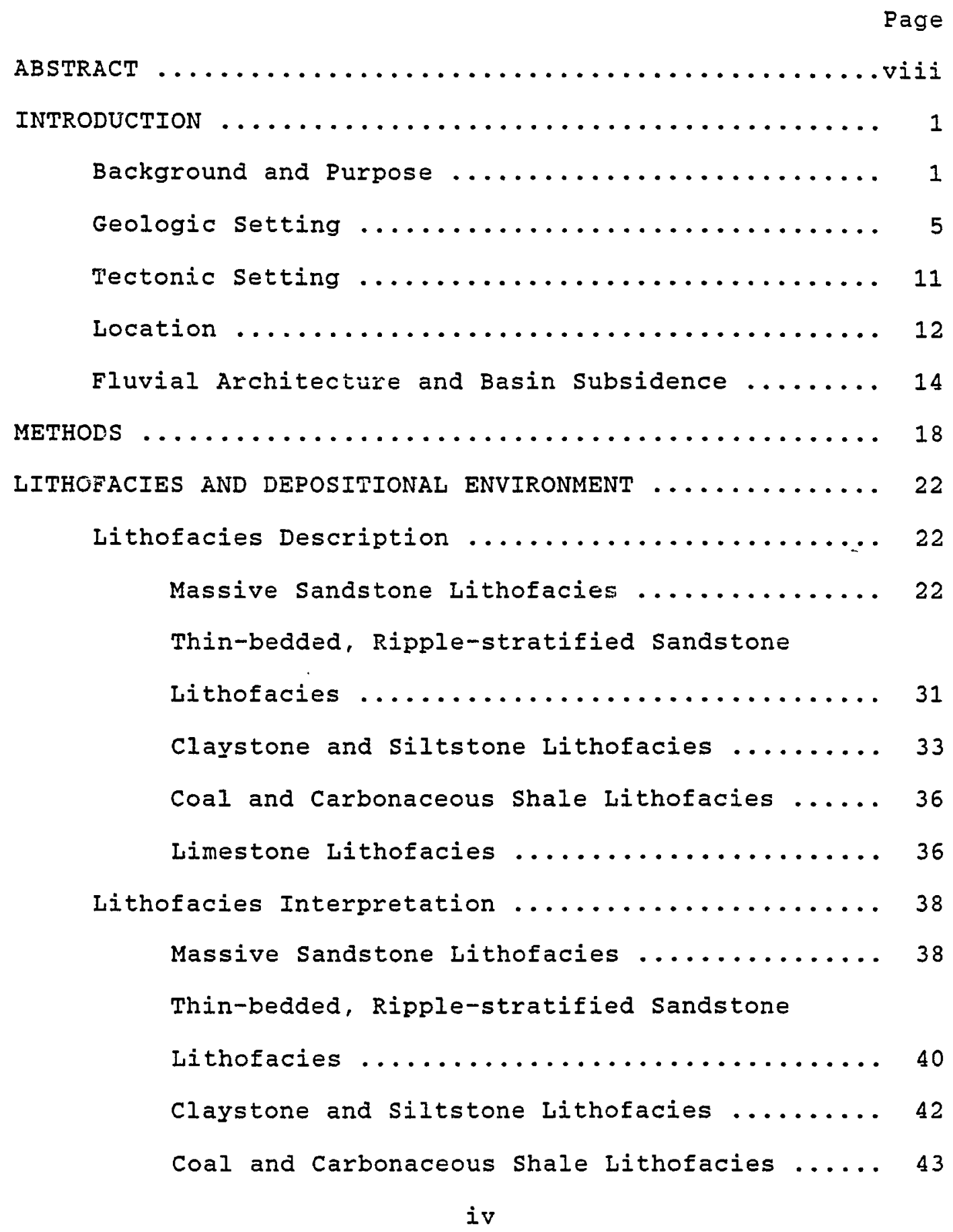




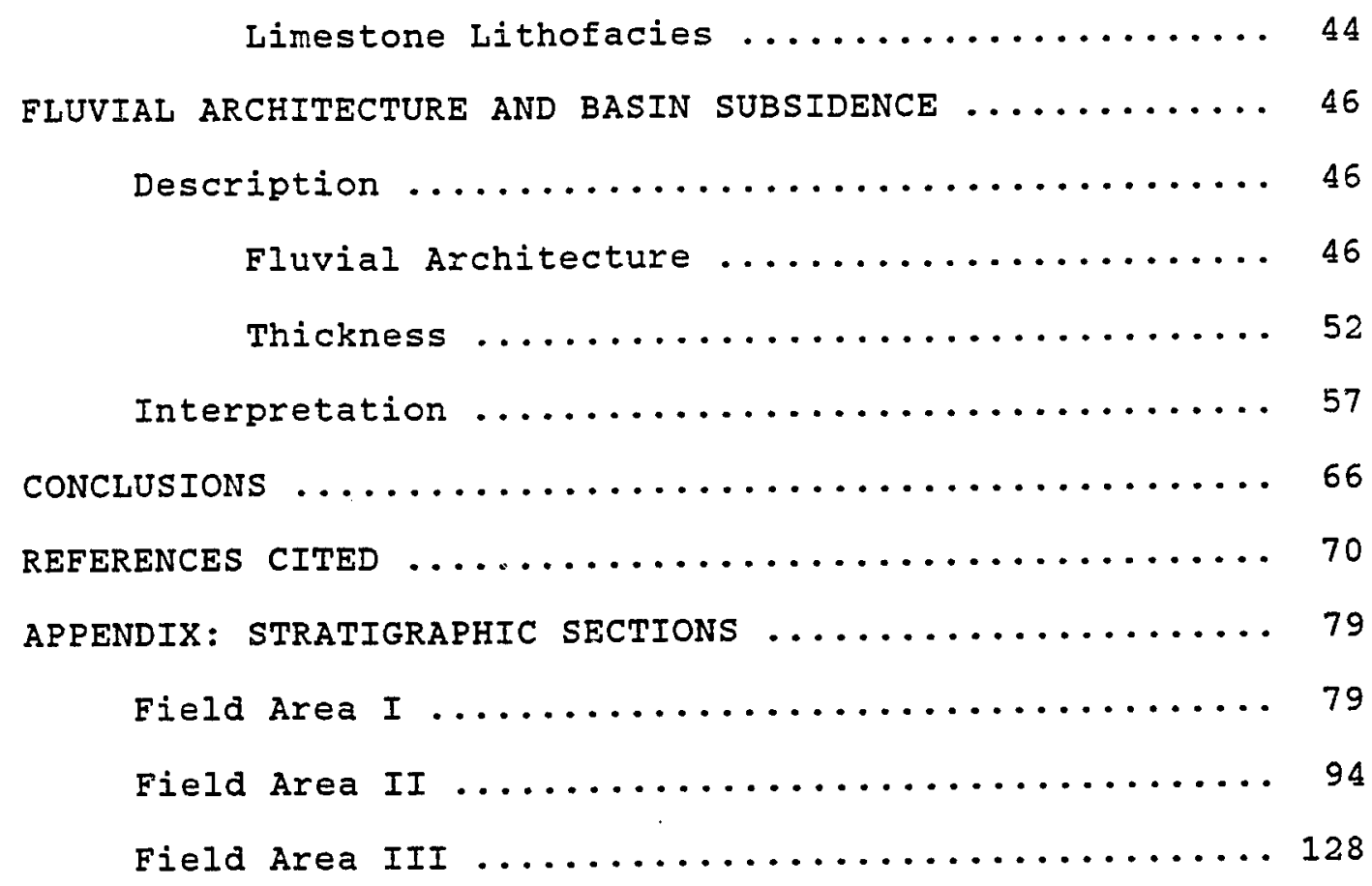


LIST OF ILLUSTRATIONS

Figure

Page

1. Location Map for Laramide Basins..

2. Map of the Greater Green River

Basin....................

3. Paleocene and Eocene Stratigraphy in the Southern Green River Basin.

4. Diagrammatic Cross-section of the Greater Green River Basin........

5. Geologic Map of the Southern Rock Springs Uplift..............

6. Mudstone Pebble Layers Exposed in a Massive Sandstone.............

7. Cross-stratification in a Massive Sandstone.................

8. Ripple-stratification in a Massive sandstone..................

9. A Lenticular Massive Sandstone and Surrounding Fine-grained Deposits.

10. Photomosaic of a Massive Sandstone of the Wasatch Formation in Field

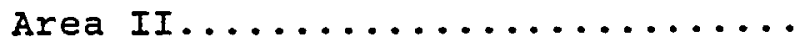

11. Photomosaic of a Massive Sandstone of the Wasatch Formation in Field

Area II...................

12. A Thin-bedded, Ripple-stratified Sandstone..................

13. Cross-stratification in a Thinbedded, Ripple-stratified Sandstone

14. Mottled Gray and Red Claystone....

15. The Coal and Carbonaceous Shale Lithofacies................ 
16. Pod-type Limestone of the Fort

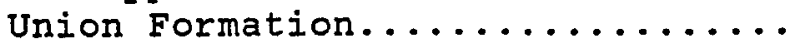

17. Diagram of Subenvironments in a

Meandering River Setting.........

18. Summary of Channel Density and Connectedness for Each Field Area.

19. Map Summarizing the Paleocurrents

for the Four Field Areas.........

20. Map Showing the Combined Thickness of the Fort Union and Wasatch Formations and Luman Tongue of the Green River Formation in the Four Field Areas.................

21. Isopach Map of the Fort Union and Wasatch Formations and Luman Tongue of the Green River Formation in the Southern Green River Basin near the Rock Springs Uplift...........

22. Location Map for Measured Sections in Field Area I...............

23. Location Map for Measured Sections in Field Area II...............

24. Location Map for Measured Sections in Field Area III.............

Plate

I. Panels for Field Areas I and II... in pocket

II. Panels for Field Areas III and IV. in pocket 


\begin{abstract}
LARAMIDE BASIN SUBSTDENCE AND FLUVIAL ARCHITECTURE OF THE FORT UNION AND WASATCH FORMATIONS, SOUTHERN GREEN RIVER

BASIN, WYOMING

by Philip I. Johnson

The Paleocene Fort Union and Eocene Wasatch formations, exposed on the flanks of the Rock springs uplift of the southern greater Green River basin, are Laramide synorogenic fluvial deposits. Thrust loading created a topographic axis near the southern margin of the basin, causing rivers from the north to flow southward across the basin toward an eastward-flowing trunk river system in the basin axis. North of the axis, where paleocurrents are southwarddirected, unit thickness and channel density are 10w, indicating slow subsidence and a wide alluvial plain. Farther south, in the basin axis field areas, thickness and channel density are greater. This is interpreted as reflecting relatively rapid subsidence and a narrow alluvial plain.

The apparent minimum rock thickness at the buried extension of the Rock springs uplift resulted either from subsidence resistance of thickened crust at the uplift or relative uplift during subsidence of the surrounding basin. The basin plain along the axis may have been constricted south of the Rock springs uplift.
\end{abstract}


INTRODUCTION

\section{Background and Purpose}

Laramide tectonic activity occurred in the Rocky Mountain region from approximately $70 \mathrm{Ma}$ to $40 \mathrm{Ma}$ (Dickinson and others, 1988), producing uplifts cored by Precambrian basement separated by basins in which thick sections of sediment were deposited. The uplifts probably resulted from thrust faulting (Brewer and others, 1980; Gries, 1983a), and the basins were depressed by flexure of the lithosphere under a thrust-emplaced load JJordan, 1981; Hagen and others, 1985; Shuster and Steidtmann, 1988).

The subsidence patterns in Laramide-style basins are poorly understood. Although isopachous maps clearly show that the thicknesses of sedimentary units vary greatly across individual basins (Sullivan, 1980), the details of subsidence within the centers of these basins are not well known. Dickinson and others (1988) compared the Laramide synorogenic basin-fill sequences for several basins and roted that the subsidence histories for these basins were difficult to reconstruct due to inadequate paleontologic age control and lack of paleoelevation indicators.

The greater Green River basin in southwest Wyoming is one of the largest Laramide basins (fig.1). The subsidence history along the northern and western margins of the basin 


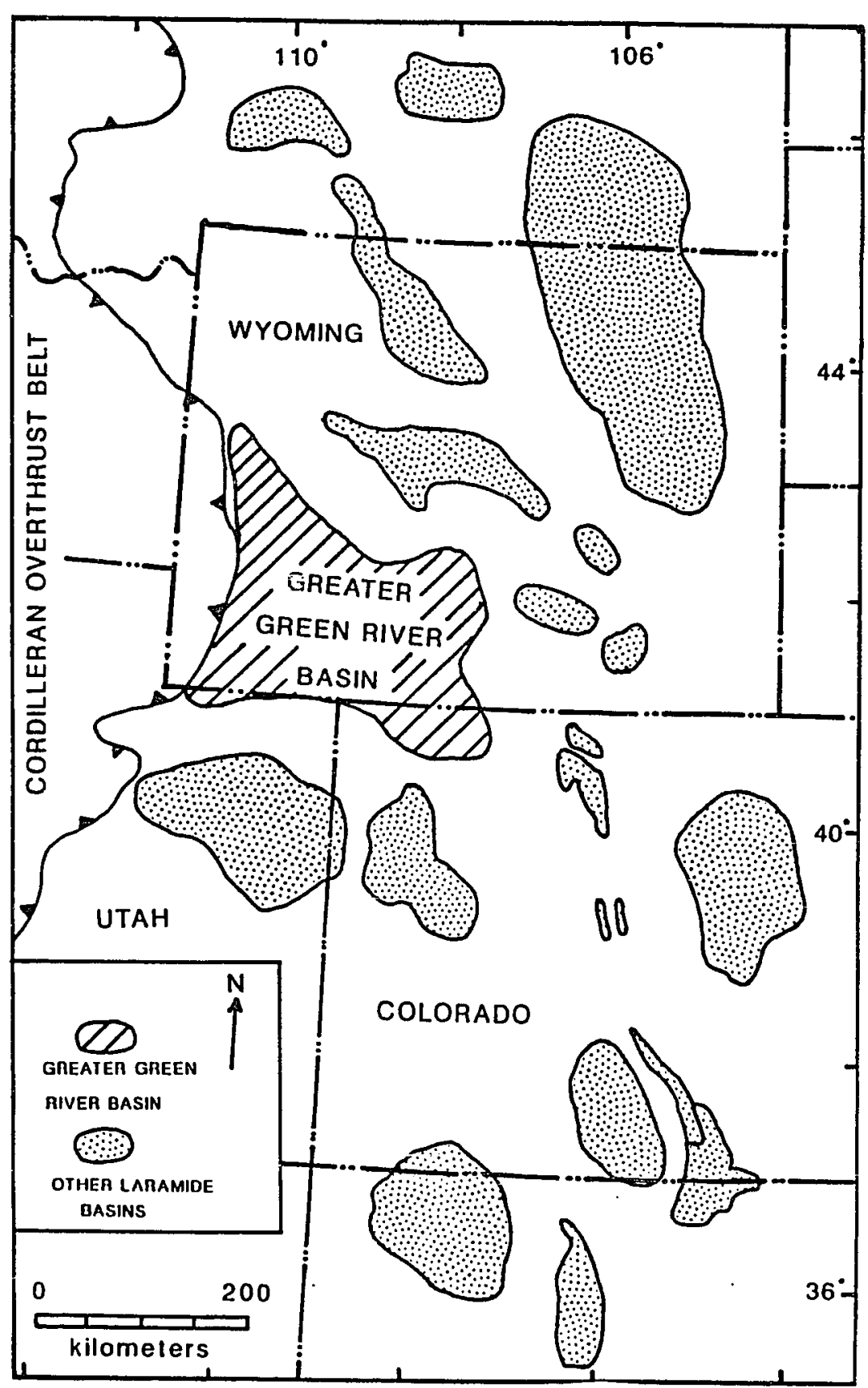

Figure 1. Location map for Laramide basins (modified from Dickinson and others, 1988). 
was studied by shuster and steidtmann (1988), but the pattern of subsidence variation across the basin center is not clear. This basin offers a good opportunity to study subsidence variation, because the sedimentary fill is exposed on the flanks of the Rock Springs uplift near the center of the basin (fig. 2).

The upper Paleocene Fort Union and lower Eocene Wasatch formations are Laramide synorogenic fluvial units in the Green River basin. Spatial differences in thickness of these units within a stratigraphic interval representing the same amount of time indicate differences in subsidence rate. In addition, the spacing of channel sandstones in overbank deposits, referred to as fluvial architecture, is in part controlled by subsidence (Allen, 1978). Channel spacing also is controlled by the width of the alluvial plain and the rate of avulsion or channel switching (Allen, 1978; Leeder, 1978).

The purpose of this investigation is to compare the fluvial architecture and combined thickness of the Fort Union Formation and main body of the Wasatch Formation at several locations around the Rock springs uplift. Differences in these characteristics are used to study spatial differences in subsidence and to interpret the sedimentary response to subsidence and paleogeography. 


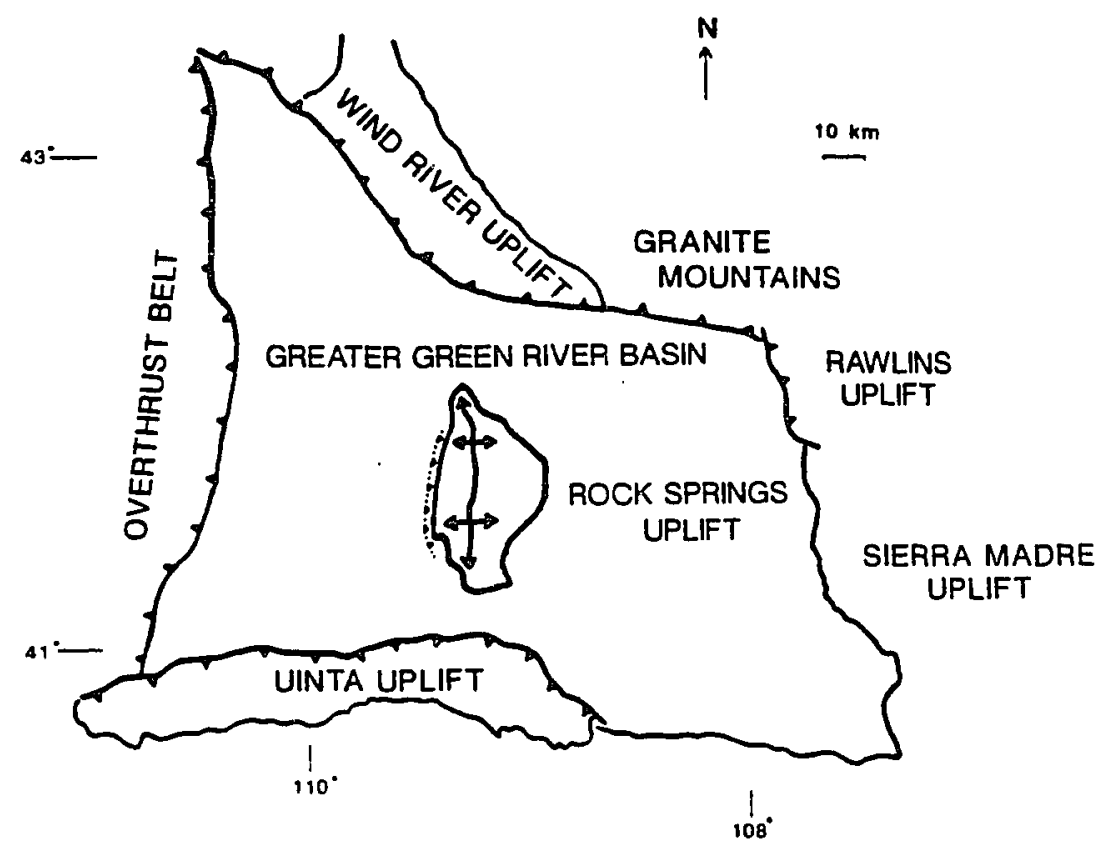

Figure 2. Map of the greater Green River basin and adjacent uplifts (modified from Sullivan, 1980; Love and Christiansen, 1985). 


\section{Geologic setting}

The Green River basin is surrounded by Laramide uplifts (fig. 2). The Uinta Mountains are located at the southern edge of the basin, and the basin is bounded at the northern edge by the Wind River Mountains and Granite Mountains. The western boundary is the Cordilleran overthrust belt, and the eastern boundary is formed by the sierra Madre and Rawlins uplift.

The Rock springs uplift is a doubly plunging asymmetric anticline located in the center of the Green River basin. It divides the basin into the Bridger sub-basin to the west and the Washakie sub-basin to the east (Love, 1961).

The Rock springs uplift developed above a blind thrust fault that cuts the underlying Precambrian basement and bounds the uplift on the western flank (Garing and Tainter, 1985). The uplift has a core of Upper Cretaceous sedimentary rocks flanked by Tertiary sedimentary rocks (Roehler, 1961).

The Paleogene fluvial and lacustrine rocks of the Green River basin are divided into three units (fig. 3): the fluvial Paleocene Fort Union Formation and overlying lower Eocene Wasatch Formation, and the overlying and interfingering lower and middle Eocene lacustrine Green River Formation. 


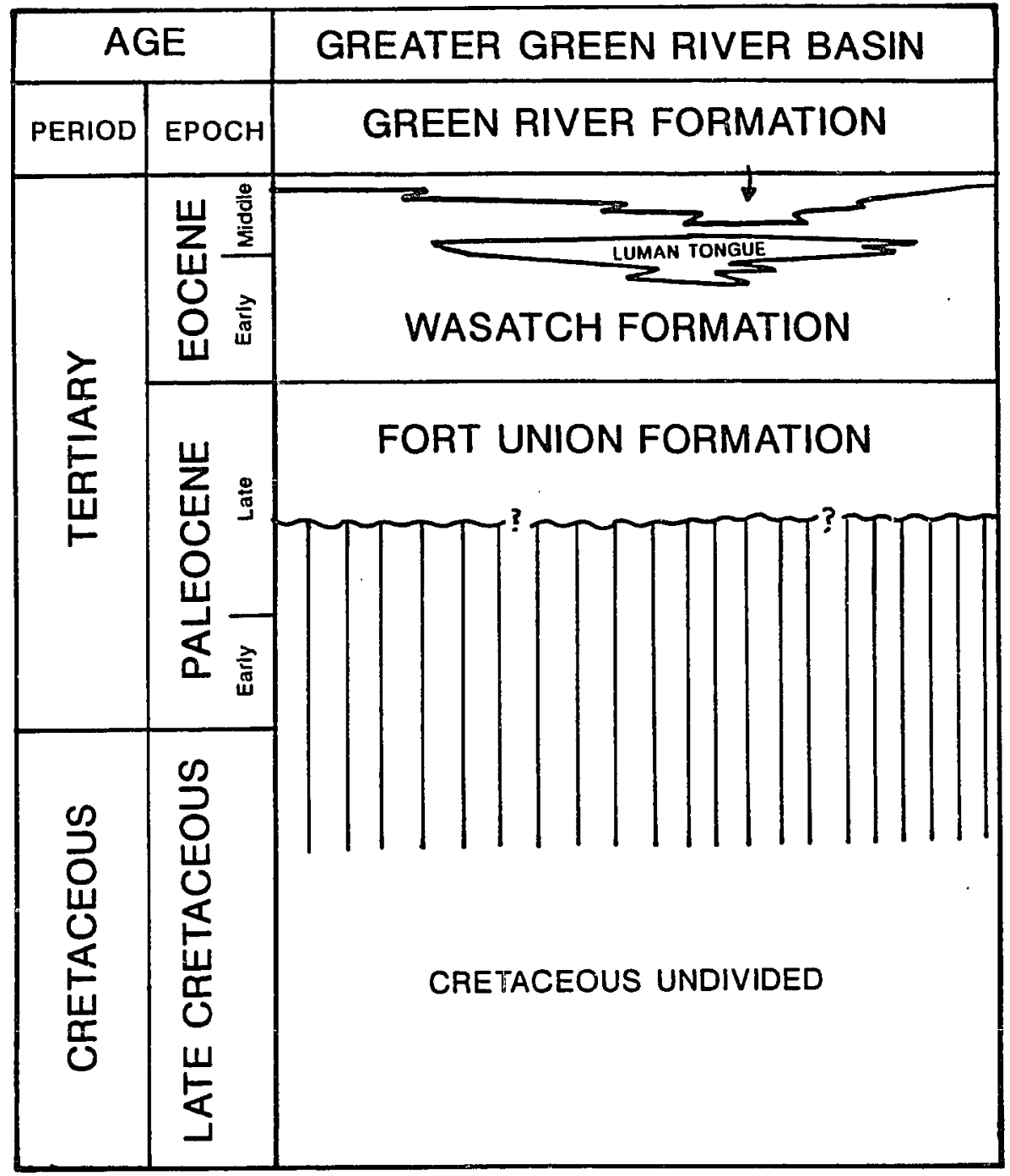

Figure 3. Paleocene and lower and middle Eocene stratigraphy in the southern greater Green River basin and Rock springs uplift (modified from Sullivan, 1980; Roehler, 1981; Helm, 1985). 
The Fort Union Formation overlies the Upper Cretaceous rocks with angular unconformity, with up to 10 degrees of angular discordance on the west flank of the uplift compared with 2 degrees or less on the east flank (Roehler, 1961). On the southeast flank, a paleosol developed on the Cretaceous rocks marks the unconformity (Ritzma, 1965).

The Fort Union Formation was first described by Meek and Hayden in 1861 (cited by Masursky, 1962) at the site of the former Fort Union, where the town of Buford, North Dakota now stands. This name has been applied to Paleocene rocks in a number of basins across the Rocky Mountain region. Because the Laramide basins are separated by considerable distances, the Fort Union Formation differs greatly from one basin to another. Brown (1949) assigned the Paleocene rocks of the Rock Springs uplift to the Fort Union Formation and placed the upper contact at the Paleocene-Eocene boundary. Helm (1985) described the interbedded sandstone, claystone, coal, carbonaceous shale, and limestone of the Fort Union Formation on the southern flank of the Rock Springs uplift and interpreted these rocks as fluvial and paludal deposits.

In the northern Green River basin, the Fort Union Formation is represented by conglomerate that, according to steidtmann and others (1986), was derived from the Wind River uplift. The basin-margin conglomerate represents 
coarse lateral equivalents to the finer-grained basin-center facies (Helm, 1985).

Plant fossils indicate that the Paleocene climate of the Green River basin was mostly subtropical and supported a forest flora (Roehler, 1979a). Plant fossils indicate a basin paleoelevation of less than $300 \mathrm{~m}$ (1000 ft.) above sea level (Roehler, 1979b). During Fort Union deposition, the nearest marine incursion was in western Nebraska and South Dakota (Keefer, 1965).

Deposition of the Fort Union Formation may not have been continuous. Roehler $(1979 b)$ traced fossil soil horizons along portions of the east flank of the Rock springs uplift. He interpreted these as intraformational unconformities. The lack of one palynomorph zone within the Paleocene rocks along the east and west flanks of the uplift (Roehler, 1979a; Kirschbaum and Nelson, 1988) supports the idea that the paleosols represent unconformities. The contact between the Fort Union Formation and the overlying wasatch Formation is mostly conformable, but Roehler (1973a) has recognized a weathered zone at this contact on the southeast flank of the Rock Springs uplift that he interpreted as a local disconformity. Placing a boundary between the Fort Union and Wasatch formations is difficult due to the similarity of the two units (Helm, 1985). Roehler (1973a, 1973b, 1973c, 1974a; 1977) attempted 
to map the contact at the Paleocene-Eocene boundary as defined by paleontologic criteria.

The Wasatch Formation was first described by Hayden in 1869 (cited by Bradley, 1964) at Echo and Weber Canyons in the Wasatch Mountains in Utah. At the type locality, it is conglomeratic, but it grades basinward into a sandstonemudstone facies. In the Green River basin, near the Uinta Mountains uplift, the Wasatch Formation consists of conglomerate deposited in an alluvial fan environment (Wray, 1988). Around the Rock Springs uplift, the Wasatch Formation contains interbedded sandstone, mudstone, coal, carbonaceous shale and limestone. The depositional setting for the Wasatch Formation at the basin center was interpreted as fluvial and paludal by Roehler (1965). Plant fossils indicate that deposition of the Wasatch Formation occurred at a paleoelevation within about $300 \mathrm{~m}$ (1000 ft.) of sea level (Roehler, 1979a) and in a humid subtropical to warm temperate paleoclimate (Roehler, 1979a; Bown and Kraus, 1981).

The sedimentary fill of the Green River basin displays a strong asymmetry. Paleocurrent measurements around the Rock Springs uplift indicate that Paleocene and Eocene rivers flowed southward across the northern part of the basin to an eastward-flowing trunk river near the southern margin of the basin (Baldwin and Andersen, 1987; Rirschbaum 
and others, 1988). The petrographic character of sandstones in the Fort Union and Wasatch formations also varies with regard to paleogeographic location within the basin (Baldwin and Andersen, 1987; Rirschbaum and others, 1988; Tollestrup and steidtmann, 1990). On the Rock springs uplift, the sandstones are feldspathic litharenites with abundant metamorphic and plutonic rock fragments. The Wind River uplift evidently was the source for most of this sediment. South of the Rock springs uplift, litharenites rich in sedimentary rock fragments occur near the Uinta Mountains. These rocks probably have a sediment source in the Uinta uplift.

Sediment derived from the Wind River uplift was transported approximately $100 \mathrm{~km}$ southward across the basin, whereas Uinta-derived sediment was transported only about 15 $\mathrm{km}$ northward into the basin. The two sediment lobes mixed in the east-west-trending topographic trough occupied by the eastward-flowing trunk river (Baldwin and Andersen, 1987). Rapid subsidence at the southern margin of the basin possibly controlled the location of the basin axis and caused the basin asymmetry (Baldwin and Andersen, 1987).

In the southern part of the Green River basin, the Wasatch Formation is conformably overlain by the lacustrine Luman Tongue of the Green River Formation (Sklenar and Andersen, 1985). The Luman Tongue and Wasatch Formation 
interfinger, and the Luman Tongue thins and pinches out to the north (Roehler, 1981). The Luman Tongue separates the main body of the Wasatch Formation from the overlying Niland Tongue of the Wasatch Formation. Because this study focuses on the main body of the Wasatch Formation, the main body will be referred to as the Wasatch Formation. In portions of the southern Rock springs uplift, the Wasatch and Fort Union Formations are unconformably overlain by the flat-lying Oligocene Bishop Conglomerate.

\section{Tectonic setting}

Thrust faulting of Precambrian basement during the Laramide orogeny resulted from regional compression in the Rocky Mountain foreland (Coney, 1978; Gries, 1983b; Bird, 1984; Brown, 1988). This compression is attributed to increased convergence rates between the North American and Farallon plates and resultant low angle subduction during Late Cretaceous and early Tertiary time (Coney, 1978; Bird, 1984).

The Green River basin originated as a result of uplift of Precambrian basement along thrust faults and loading the lithosphere of the adjacent footwall (Beck and others, 1988), producing flexural subsidence (fig. 4). Flexural subsidence is modelled as the response of an elastic or 




Figure 4. Diagrammatic cross-section of the greater Green River basin west of the Rock Springs uplift (after Beck and others, 1988). 
visco-elastic lithosphere to a tectonic load (Beaumont, 1981; Jordan, 1981). Loading from the Wind River uplift caused subsidence of the northern Green River basin (Hagen and others, 1985). In the southern portion of the basin, subsidence resulted from loading by the Uinta Mountains uplift (Beck and others, 1988).

Seismic surveys and well data indicate that the Wind River fault, bounding the Wind River uplift, and the Henry's Fork and Uinta-Sparks faults, bounding the Uinta uplift are thrust faults. Wells drilled through the cores of both uplifts have penetrated Tertiary basin fill beneath the uplift-bounding faults (Gries, 1983a). Seismic reflection profiling shows that the wind River fault dips 30 to 35 degrees to the northeast (Brewer and others, 1980).

\section{Location}

This study was conducted within well-exposed portions of the Fort Union and Wasatch formations on the east, west and south flanks of the Rock springs uplift (fig. 5) in Sweetwater County, Wyoming. Four locations, called field areas I, II, III and IV, were chosen for study for their continuous exposure. Field area $I$ is located on the east flank of the Rock springs uplift and covers an area of approximately 2 square kilometers. Area II is a roughly 12- 


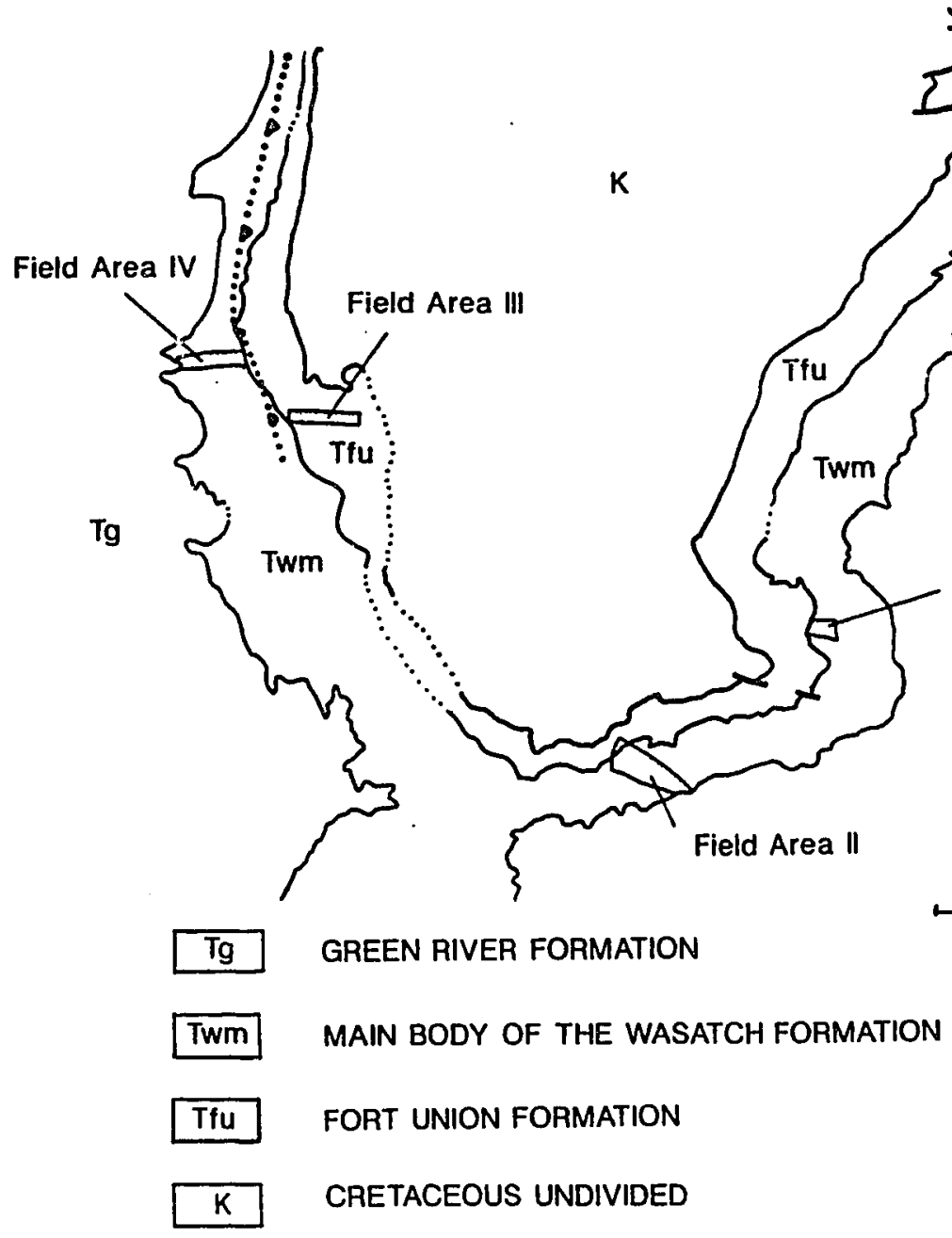

Figure 5. Simplified geologic map of the southern Rock springs uplift (after Love and Christiansen, 1985) showing field areas I through IV. Light lines are stratigraphic contacts, dotted where concealed. Heavy lines represent fault traces. Teeth are shown on the upper plate of a blind thrust on the western margin of the Rock springs uplift. 
square-kilometer area located on the south flank of the Rock springs uplift. Areas III and IV are on the west flank of the Rock springs uplift. Field areas III and IV cover 5 and 3 square kilometers, respectively.

\section{Fluvial Architecture and Basin Subsidence}

A number of workers have modelled alluvial stratigraphy in subsiding basins. Allen (1978) described the alluvial sequence created by a hypothetical river flowing across a broad coastal plain. He reasoned that the number of sand bodies in a stratigraphic sequence depends upon the width of the alluvial plain, the avulsion frequency, and the subsidence rate. By holding the other variables fixed and varying the subsidence rate, he found that sand body density within overbank "fines" was inversely proportional to subsidence rate. Channel sandstones become more widely spaced as subsidence rate is increased.

Avulsion, the abandonment of a channel and development of a new channel course, also is an important factor in determining channel sandstone distribution. Channel sandstones become smaller and more widely distributed as the frequency of avulsion is increased (Allen, 1978).

The width of the alluvial plain is another important variable. For a given rate of subsidence, channel deposits 
are more closely spaced where a river works across a narrow alluvial plain than across a wide one (Allen, 1978; Leeder, 1978).

Blakey and Gubitosa (1984) interpreted variations in fluvial channel distribution in the Chinle Formation of the Colorado Plateau as the product of variation in subsidence rate. Clustering of channels in several members of the Chinle Formation was interpreted to suggest periods of slow subsidence, and members containing widely-spaced sandstones were inferred to reflect phases of rapid subsidence. Bridge and Leeder (1979) applied a computer model of alluvial stratigraphy to an asymmetrically subsiding halfgraben. Due to the slope of the floodplain, a river flowing parallel to the graben axis was localized where the rate of subsidence was greatest. In the case of spatial variation of subsidence rate, the model showed channel sandstones clustered near the faulted margin of the basin where subsidence was greatest. Alexander and Leeder (1987) demonstrated that a meandering river system within the axis of a half-graben should tend to avulse toward the area of maximum subsidence, and Leeder and Alexander (1987) showed that the asymmetric meander belt of the South Fork Madison River in Montana formed in this way.

The alluvial stratigraphy predicted for a half-graben (Bridge and Leeder, 1979) differs markedly from the model of 
an evenly subsiding coastal basin (Allen, 1978). In an evenly subsiding basin, sandstone body density decreases as the subsidence rate increases. If there is spatial variation in subsidence in an asymmetric basin, sandstone body density is highest in the location where the subsidence rate is highest, because the basin axis rivers are confined to a narrow alluvial plain. These two models of alluvial stratigraphy predict very different effects from temporal and spatial variation in subsidence rate.

The observed patterns of fluvial architecture and subsidence in the Green River basin can be compared with the predictive models of alluvial stratigraphy in order to understand the development of the basin. Investigation of subsidence patterns and the response of the fluvial system to subsidence variations is fundamental to the understanding of the tectonic development of the basin. 
METHODS

This field study was conducted by measuring and correlating stratigraphic sections and by constructing photomosaics of individual sandstone bodies. The largescale architecture was visually displayed through the construction of diagrams showing the distribution of channel sandstone bodies in floodplain deposits, and the depositional environment was inferred through the use of photomosaics that depict the geometry of bounding surfaces within individual channel sandstones. The total thickness of the units was determined from the sections measured in the field and thicknesses compiled from other sources.

The primary method used in this study was the measured section. Each section includes a description of each lithologic unit and its measured thickness. The rock units were described in the field. Color was described using the Geological Society of America Rock Color Chart (Goddard and others, 1951). The classification scheme of McRee and Weir (1953) was used to describe bed thickness and splitting character. Stratification types were classified using the nomenclature of Harms and others (1982). The sandstones were described using the grain size classification of Wentworth (1922), and fine-grained rocks were classified according to the system of Picard (1971).

Most sections were measured with a Jacob's Staff, 
because this method was well suited to the terrair of the field areas. Where the slopes are very steep, such as at cliff-forming sandstones, thicknesses were determined using the measuring tape and compass method of Compton (1985).

The boundaries of the Fort Union and Wasatch formations were taken from published maps. Detailed geologic maps are available for areas I and II (Roehier, 1973a, 1973b), but for areas III and IV, the contacts were inferred from a less detailed map (Love and Christiansen, 1985) and known stratigraphic relations (Roehler, 1981).

Although no single section includes the entire thickness of any formation, the detailed stratigraphy allows accurate correlation within a single field area.

Correlation was accomplished primarily by tracing individual beds in outcrop and on photographs.

Paleocurrent measurements were taken from the orientation of trough and tabular-planar cross-bed sets within the channel sandstones. The average direction of paleoflow was determined from the vectoral resultant of paleocurrent measurements for each field area using the method of Picard and Andersen (1975).

Panel diagrams were constructed for each field area. Panel diagrams are cross-sections that depict the distribution of channel sandstones within the surrounding floodplain deposits. These panels show, as precisely as 
possible, the location, thickness, lateral extent and approximate geometry of each channel sandstone within the area of outcrop. They were constructed in a plane perpendicular to the average paleocurrent direction for the field area by projecting the lateral extent of each sandstone body into the plane of cross-section. Each panel provides a view of channel distribution transverse to the paleoflow.

In compiling thicknesses, the thickness of the Fort Union and wasatch formations were added together, because both formations represent a single genetic unit. The base of the Fort Union Formation is of approximately constant age around the Rock Springs uplift (Kirschbaum and Nelson, 1988), but it may be different away from the uplift. The thickness of the Luman Tongue of the Green River Formation was also added to the combined Fort Union and Wasatch thickness, because, in the southernmost part of the basin, the upper portion of the main body of the Wasatch Formation interfingers with the Luman Tongue and is partly coeval with it. Roehler (1981) has shown that the upper contact of the Luman Tongue has a more constant age than the base.

In order to determine the depositional environment of the Fort Union and Wasatch formations, photomosaics of the internal geometry of the channel sandstones were prepared. First, channels with very well-exposed internal 
stratification were photographed. Specifically, several

photographs of each of two channels from the Wasatch

Formation were taken and combined to form larger composite

photographs of the individual sandstones. These composites

were taken back into the field and important internal

bounding surfaces were drawn directly onto the photos. The completed photomosaic provides a graphic display of the bounding surfaces within each sandstone. A more accurate interpretation of depositional environment is possible from this detailed description than from a vertical column alone (Miall, 1983). 


\section{LITHOFACIES AND DEPOSITIONAL ENVIRONMENT}

Field descriptions of measured sections of the Fort Union and Wasatch formations in the area of the Rock springs uplift are given in the appendix. These units contain the same five lithofacies: massive sandstone; thin-bedded, ripple-stratified sandstone; claystone and siltstone; coal and carbonaceous shale; and limestone.

\section{Lithofacies Description}

Massive Sandstone Iithofacies

The massive sandstone lithofacies is expressed by large sandstone bodies that form thick, resistant outcrops. These thick-bedded, cross-stratified sandstones are referred to as massive (Mckee and Weir, 1953), because they split into blocks larger than $1.2 \mathrm{~m}$.

The massive sandstone lithofacies consists mostly of medium-grained sandstone with calcite cement. The lower portion typically contains mudstone pebbles generally in medium-grained and rarely in coarse-grained sandstone. Commonly the upper sandstone fines upward into the overlying fine-grained deposits. The unweathered sandstone is lightgray, whereas the weathered sandstone ranges from yellowishgray to reddish-brown in color.

Individual massive sandstone bodies display an 
erosional base with an irregulax surface produced by scour into the underlying deposits. Mudstone pebbles commonly occur within the sandstone directly above the erosional base (fig. 6).

Typically, beds are thick to very thick in the lower portion of a sandstone unit and decrease in thickness upward to thin beds at the top. Trough cross-stratification is present in the basal and central portions of most massive sandstones (fig. 7), whereas, ripple-stratification is typical of the top (fig. 8). Massive sandstone locally contains convoluted bedding that indicates soft sediment deformation. Portions of the massive sandstone that completely lack visible stratification are referred to as "unstratified" sandstone.

Massive sandstone bodies may extend for up to $2 \mathrm{~km}$ before terminating by pinching out, which produces a lenticular shape (fig. 9). Locally, beds of the thinbedded, ripple-stratified sandstone facies are continuous with the massive sandstone at pinch outs. The thickness of the massive sandstone generally exceeds $2 \mathrm{~m}$ and in places is as much as $18 \mathrm{~m}$. Massive sandstone typically is 8 to $10 \mathrm{~m}$ thick. Amalgamation of two or more massive sandstone bodies produces a multi-story sandstone. The thickest multi-story sandstone is $25.1 \mathrm{~m}$ and occurs in section $\mathrm{K}$ of field area II (appendix, p. 106). 


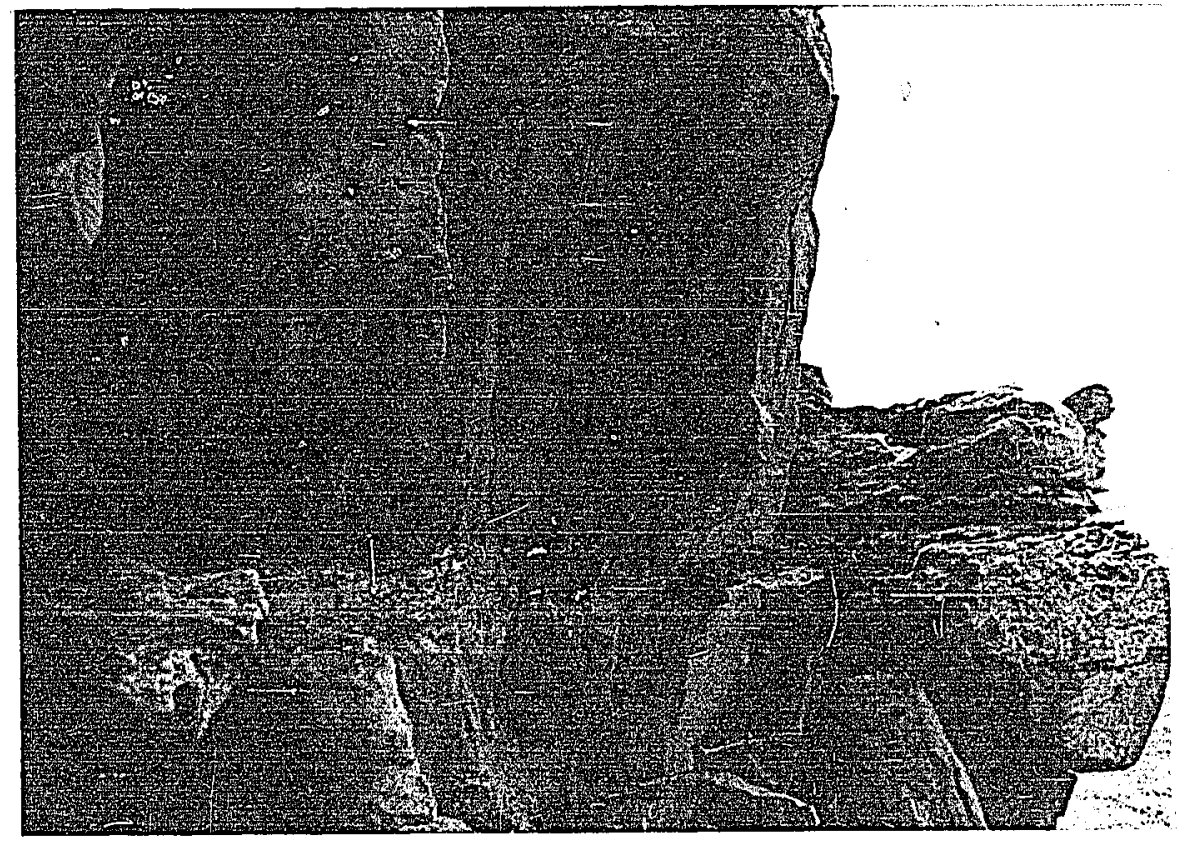

Figure 6. Mudstone pebble layers (near hammer) exposed in the lower portion of a massive sandstone in the Wasatch Formation of field area II. 


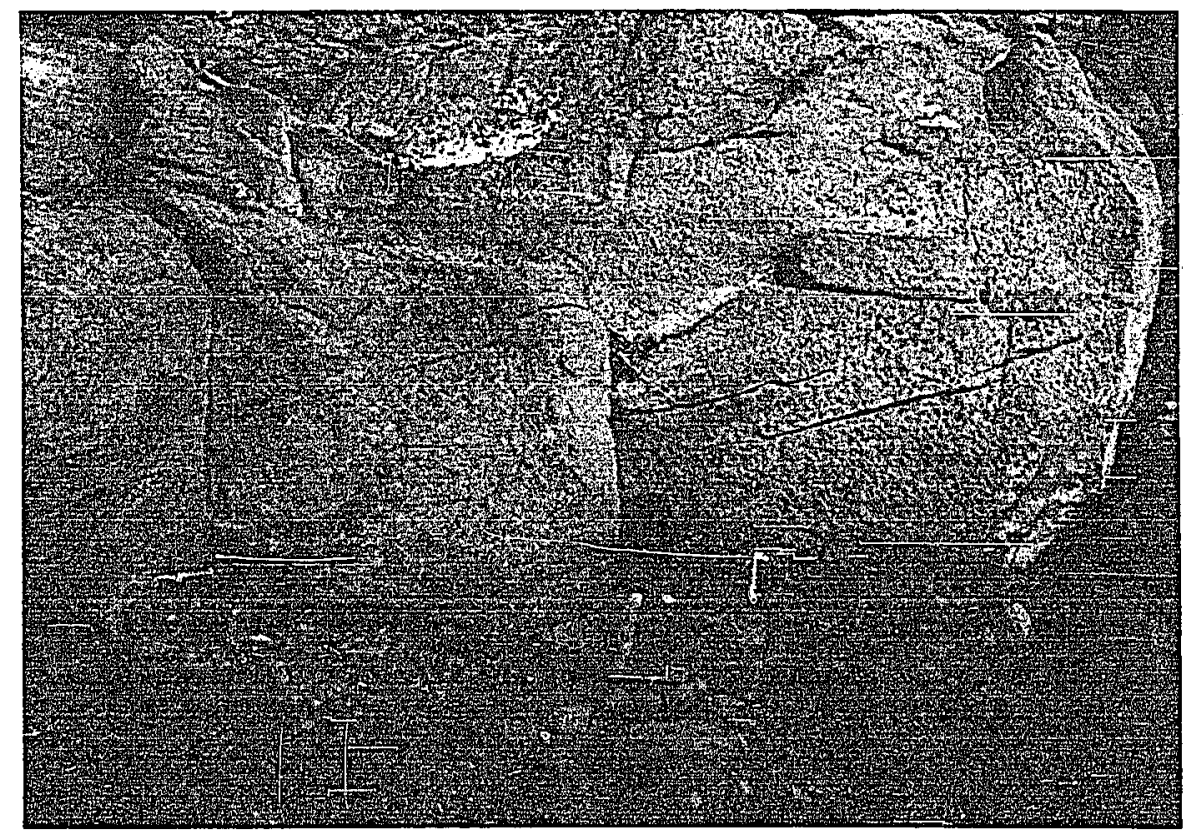

Figure 7. Cross-stratification in a massive sandstone in the Wasatch Formation of field area II. The hammer is approximately $30 \mathrm{~cm}$ long. 


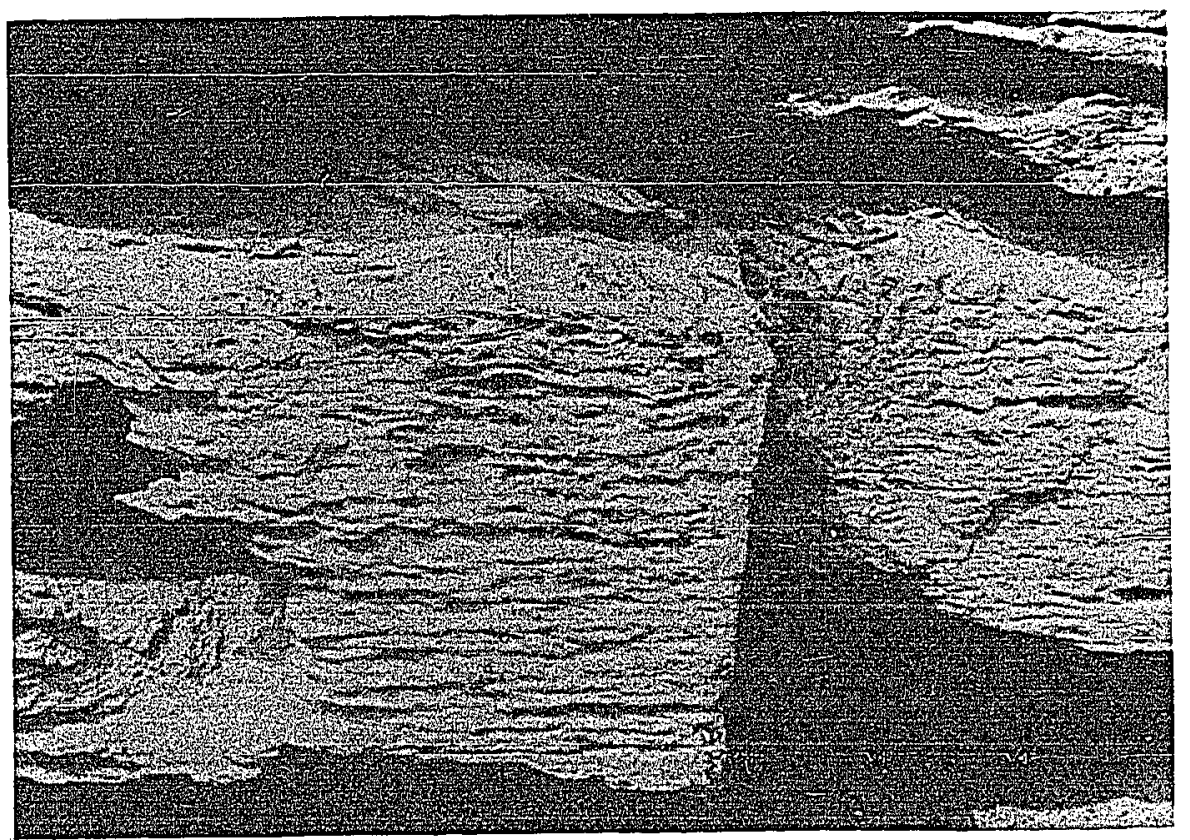

Figure 8. Ripple-stratification in the upper portion of a massive sandstone in the Wasatch Formation of field area II. The field of view is approximately $40 \mathrm{~cm}$ in width. 


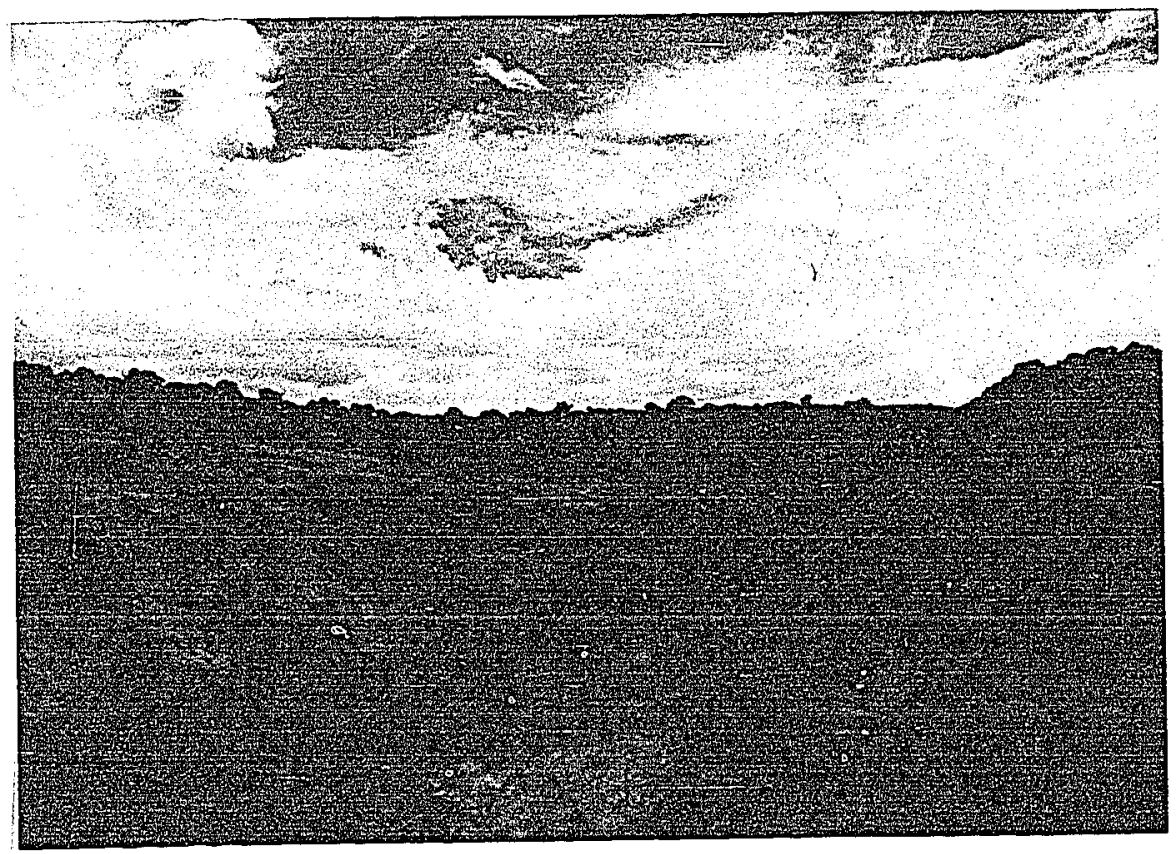

Figure 9. A lenticular massive sandstone and surrounding fine-grained deposits in the Wasatch Formation of field area I. Arrow points to sandstone pinch-out. 
The internal stratification of several massive sandstones was studied in detail. The results of this sudy are depicted by photomosaics in figures 10 and 11 .

Massive sandstone contains long, gently inclined stratification surfaces. These prominent stratification surfaces truncate cross-bed set boundaries and can be traced from the top of the massive sandstone down to the base. Miall (1988) called these third-order surfaces. An example of third-order surfaces within a massive sandstone occurs in the wasatch Formation in field area II (fig. 10), where subparallel third-order surfaces extend through the entire sandstone body. Near the base, thirdorder surfaces are directly overlain by a layer of mudstone pebbles. Farther upward along these surfaces, the basal mudstone-pebble layers pinch out. The pebble layers are overlain by cross-stratified sandstone in which bed thickness diminishes upward along the third-order surface. Cross-stratification gives way to ripple stratification at the top of the sandstone. Along each surface, grain size decreases upward from coarse- to medium-grained sandstone. A vertical sequence through this massive sandstone outcrop across third-order surfaces shows a similar upward succession of grain sizes and stratification types, as inclined units bounded by third order surfaces are stacked upon each other. 


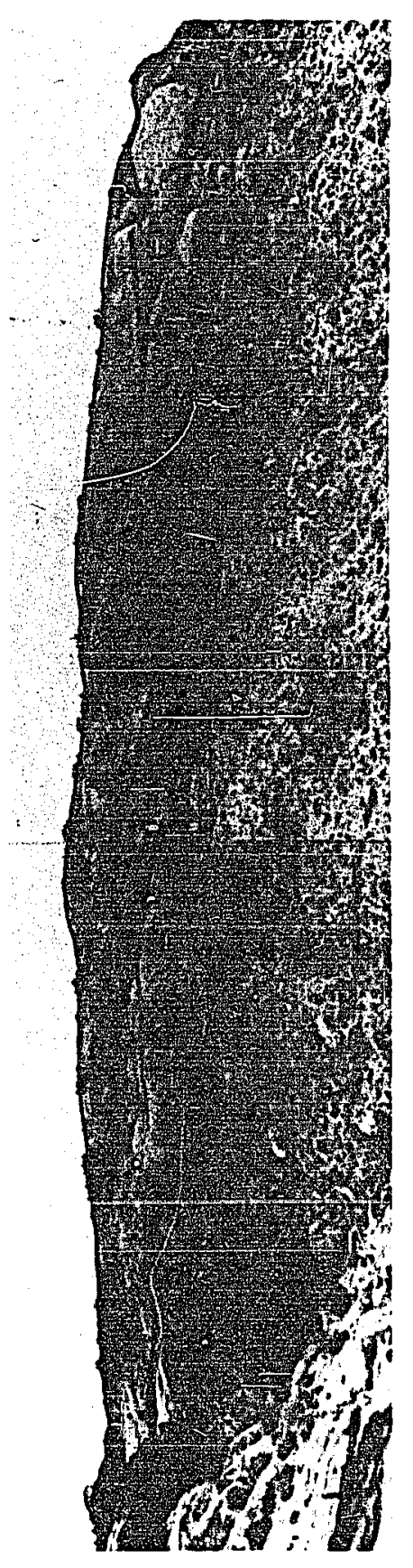

起

岁运总要

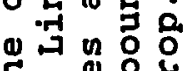

ํㅗㄹ.

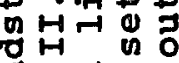

菏



(1) 㟧

$\rightarrow$ o n

.

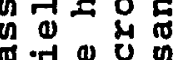

E

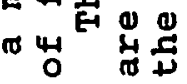

出 0 in

○ ⿷

न

需出出

约

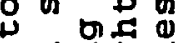



ब

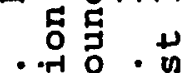

뭉

$\rightarrow \pi$

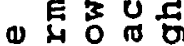

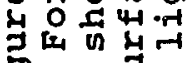

бा

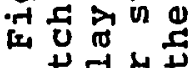

岁年

ชู

ङ 

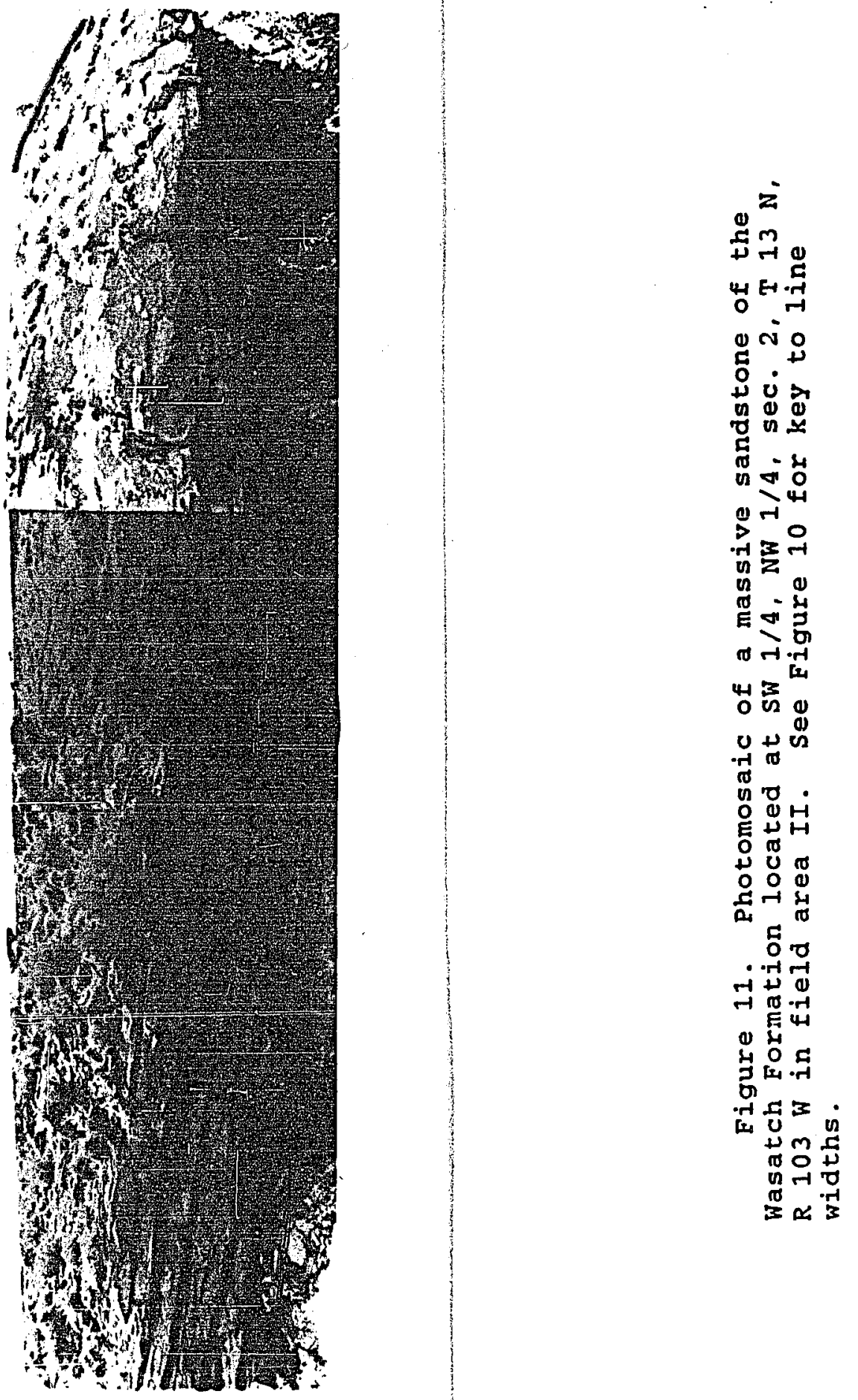
A second example also is in the Wasatch Formation in field area II (fig. 11). In this outcrop, as before, crossbed sets are truncated by gently dipping, parallel to subparallel third-order surfaces. The bed thickness decreases upward along the third-order surfaces. Most of the sandstone is cross-stratified, but ripple stratification was noted in the upper left portion of the outcrop (fig. 11), near the top of the sandstone body. Near the base of the sandstone body, mudstone-pebble layers occur above each third-order surface. The entire outcrop is composed of medium-grained sandstone except for mudstone pebbles near the base.

Thin-bedded, Ripple-stratified Sandstone Lithofacies The thin-bedded, ripple-stratified sandstone lithofacies consists of fine- to very fine-grained sandstone and minor medium-grained sandstone with calcite cement. It is mostly light gray on fresh surfaces, whereas weathered surfaces may be yellowish-gray to reddish-brown.

Bioturbation, especially at the top of the sandstone, is represented by numerous vertical tubular burrows. Some of the sandstone lacks visible stratification.

This lithofacies commonly is ripple-stratified (fig. 12), and it is locally cross-stratified. The crossstratified sandstone typically overlies ripple-stratified 


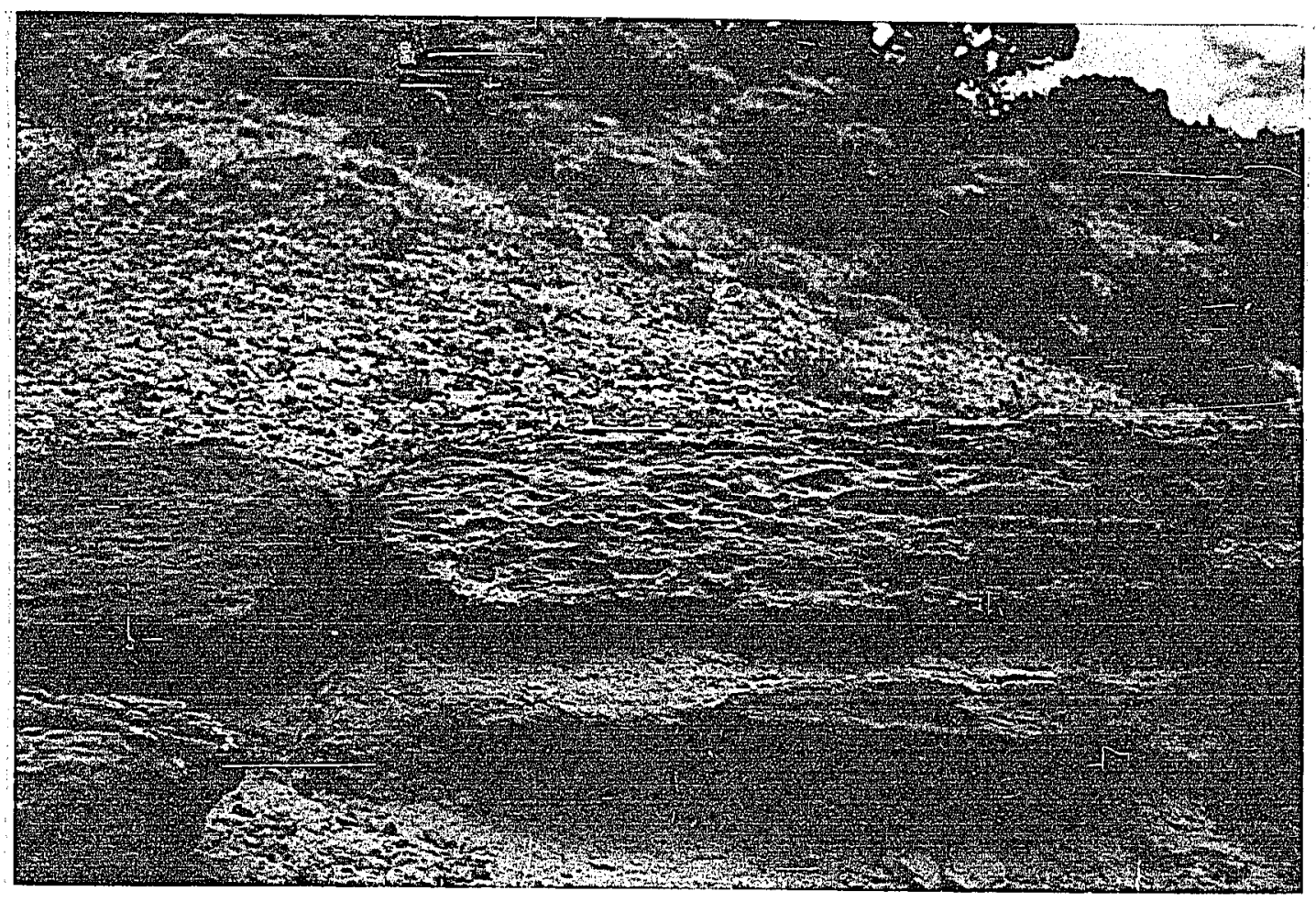

Figure 12. A thin-bedded, ripple-stratified sandstone in the Wasatch Formation of field area $I$. Pencil is approximately $15 \mathrm{~cm}$ long. 
sandstone (fig. 13).

The lower boundaries of these sandstones are either gradational or sharp. Where there is a coarsening upward from the underlying facies, the sandstone has a gradational lower boundary. The upper boundary of the sandstone generally is sharp.

The thin-bedded, ripple-stratified sandstones generally are laterally extensive and thin. Thicknesses rarely exceed $2 \mathrm{~m}$. They can merge laterally with massive sandstones, and they commonly fine and thin away from the massive sandstones. The lateral extent of these sandstones generally is 1 to $2 \mathrm{~km}$. They terminate where they fine and pinch out. Where a thin-bedded, ripple-stratified sandstone pinches out, it fines and interfingers with claystone and siltstone.

Claystone and Siltstone Lithofacies

Rocks of this poorly exposed lithofacies range from claystone to clayey siltstone, and most are silty claystone in the usage of Picard (1971). Individual claystone and siltstone beds range from less than $5 \mathrm{~cm}$ to several meters thick. An example of a well-exposed claystone is shown in Figure 14. The color of the claystone and siltstone ranges from light gray to moderate red. 


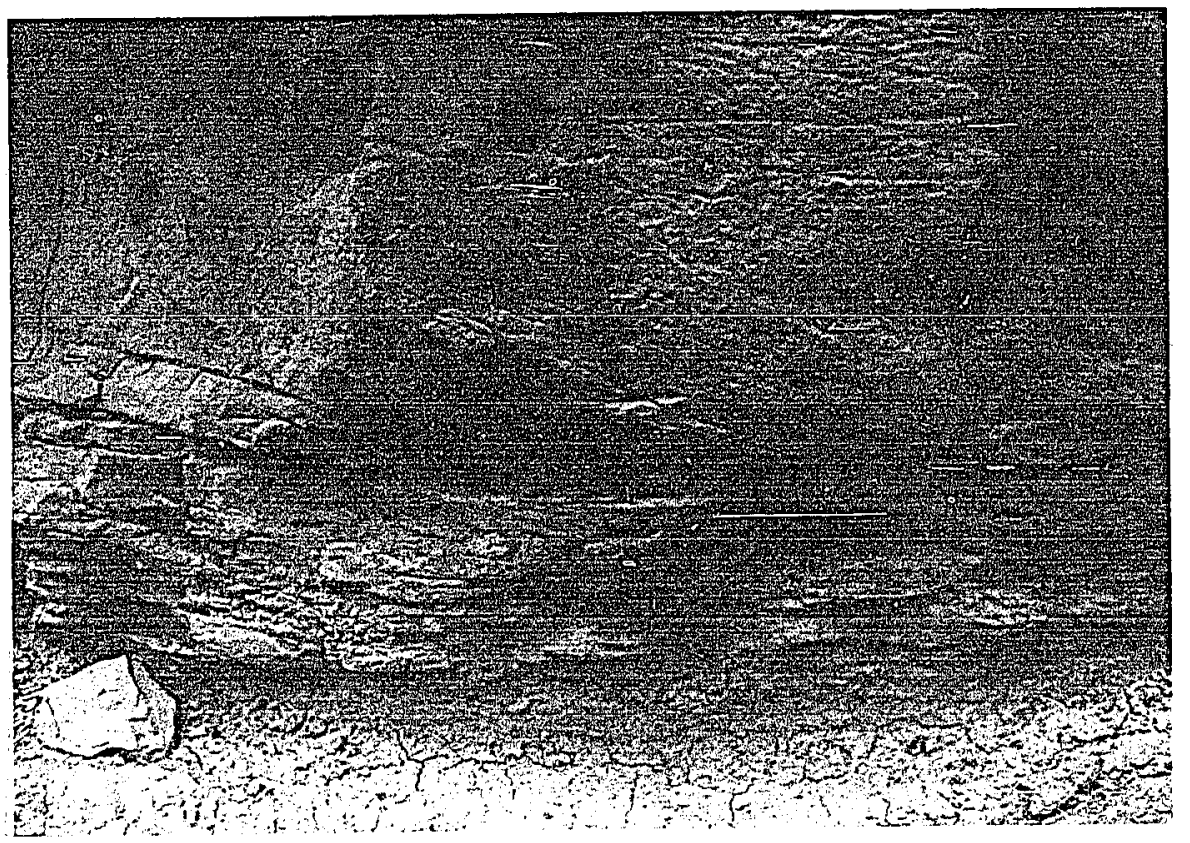

Figure 13. Cross-stratification in a thin-bedded, ripple-stratified sandstone in the Wasatch Formation of field area III. The basal contact with underlying claystone is gradational, and grain-size coarsens upward from very fine- to medium-grained sandstone. The lens cap in the photograph is approximately $5 \mathrm{~cm}$ in diameter. 


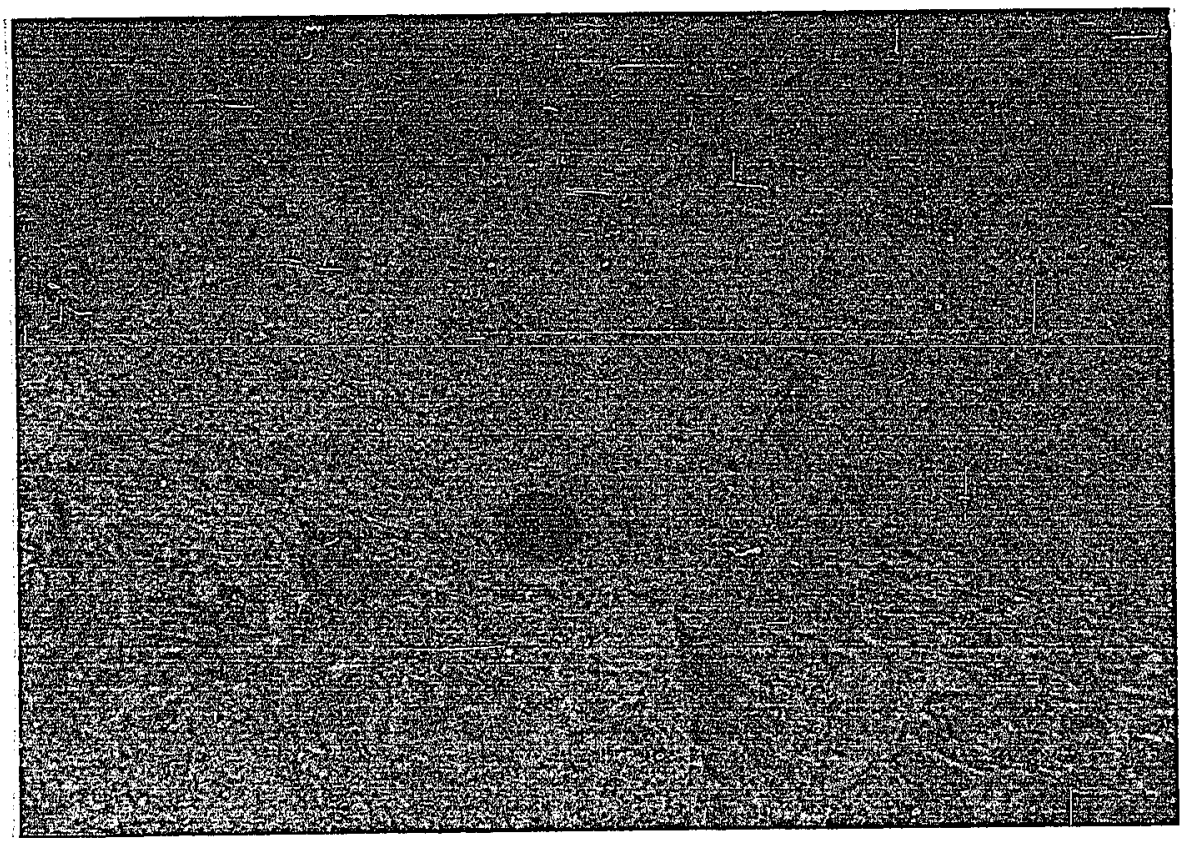

Figure 14. Mottled gray and red claystone of the Wasatch Formation in field area III. 
Coal and Carbonaceous Shale Lithofacies

The coal and carbonaceous shale lithofacies consists of organic matter with various amounts of silt and clay. Both rock types contain plant fossils. Carbonaceous shale ranges from pale brown to brownish black with a thickness from $2 \mathrm{~cm}$ to $20 \mathrm{~cm}$. Coal, which ranges in thickness from $2 \mathrm{~cm}$ to $2.4 \mathrm{~m}$ is grayish black to black (fig. 15).

Coal and carbonaceous shale units extend laterally up to $4 \mathrm{~km}$ or more. The lateral extent of some coal beds was utilized by Rirschbaum (1987) for correlation between measured sections in the Fort Union Formation on the west flank of the Rock springs uplift.

\section{Limestone Lithofacies}

This lithofacies generally consists mainly of coquinal or micritic limestone. Coquinal limestones contain whole fossils or fragments of gastropods, pelecypods or ostracodes in a grain-supported rock with a fine-grained matrix. The micritic limestone consists of structureless microcrystalline calcite. Silt- to fine sand-size siliciclastic grains also occur in some limestones.

Most of the pale-yellowish-brown to dark-gray limestone has little or no internal stratification. A few limestones contain ripple stratification.

Limestones in the Wasatch Formation differ from those 


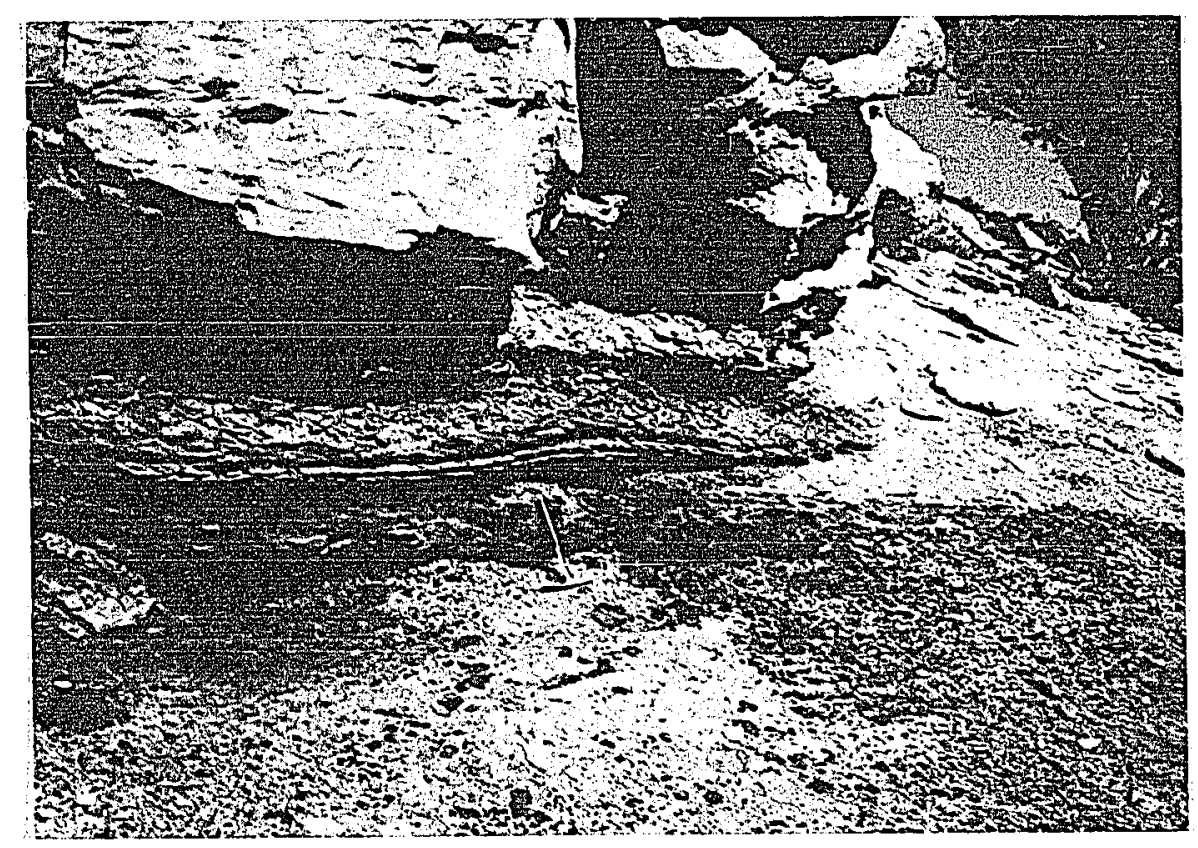

Figure 15. The coal and carbonaceous shale lithofacies of the Wasatch Formation in field area III. 
in the Fort Union Formation. The former are laterally extensive; individual beds can be traced for kilometers (Roehler, 1973b), and many are coquinal. The Fort Union Formation contains limestone that is less extensive and less fossiliferous than that in the Wasatch. Most of these limestones consist of discontinuous 1 - to $2 \mathrm{~m}$-wide pods, confined to discrete stratigraphic horizons. These pods are composed of sandy micrites that weather pale brown and tend to break along vertical fractures (fig. 16). They commonly occur directly above a thin-bedded, ripple-stratified sandstone.

\section{Lithofacies Interpretation}

Massive Sandstone Lithofacies

The massive sandstone lithofacies is interpreted as a fluvial channel sandstone, because of its erosional base, the sequence of stratification types, the lenticular or channel-form shape, and interbedding with claystone and coal, which are all common features of fluvial channels (Miall, 1985).

The third-order surfaces are interpreted as lateral accretion surfaces (Miall, 1988). The parallel to subparallel orientation and consistent dip direction of third order surfaces shown in figures 10 and 11 are typical 


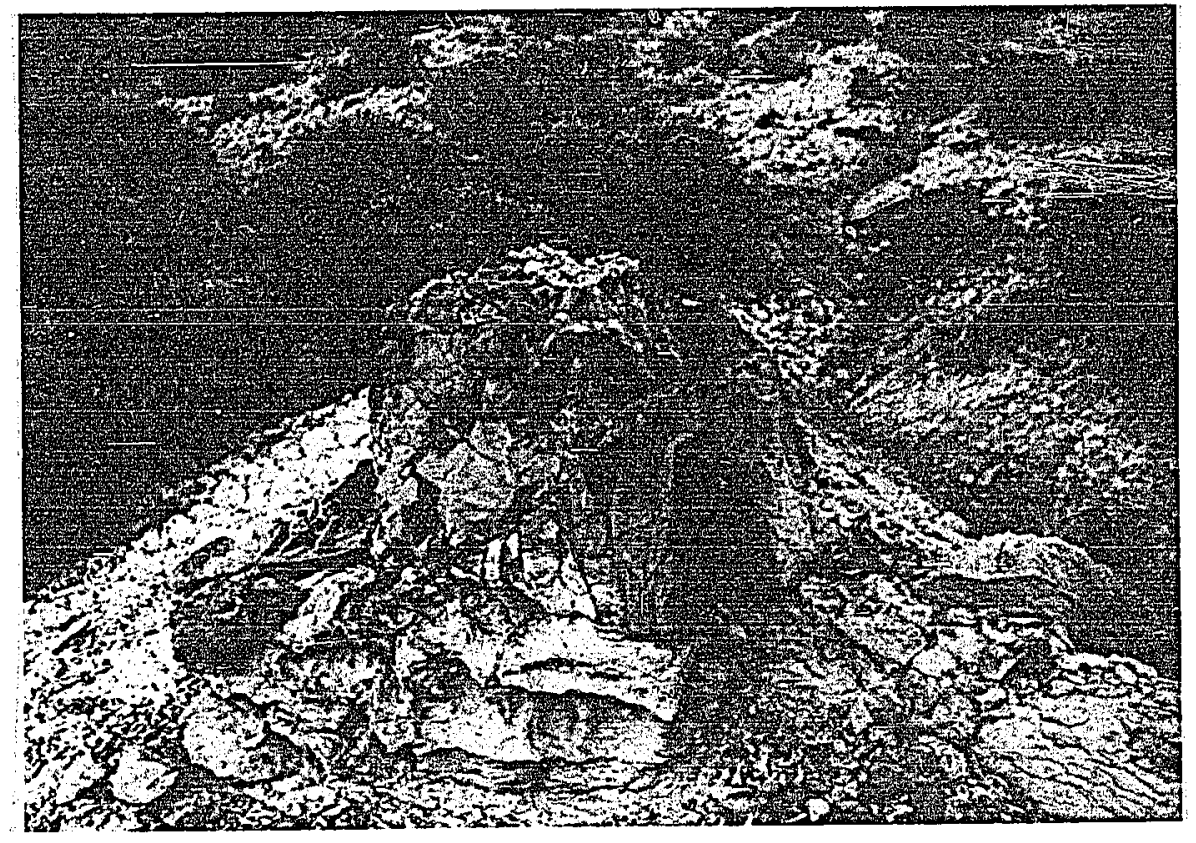

Figure 16. Pod-type limestone of the Fort Union Formation in field area II. 
of lateral accretion, as is the enclosure of crossbed sets within these surfaces. Because these lateral accretion surfaces dip consistently in one direction through the entire thickness of most channel sandstones, these deposits are inferred to represent point bars of meandering streams (fig. 17).

The vertical sequence of stratification types and grain sizes resembles that summarized by Allen (1970) for meandering stream deposits of the old Red Sandstone of Britain. The decrease in size of the stratification types reflects a decreasing flow velocity upward such as that found on a point bar. Although most massive sandstones have little grain size variation, the fining upward that occurs in some massive sandstones is also indicative of decreasing flow velocity.

Thin-bedded, Ripple-stratified Sandstone Lithofacies The thin-bedded, ripple-stratified sandstones are interpreted as interchannel deposits resulting from overbank deposition of sand. The ripple-stratification indicates that deposition occurred at low flow velocities (Harms and others, 1982) as flow overtopped or breached the river banks.

Interchannel sandstones in the study area include those with cross-stratification and those that lack it. The 


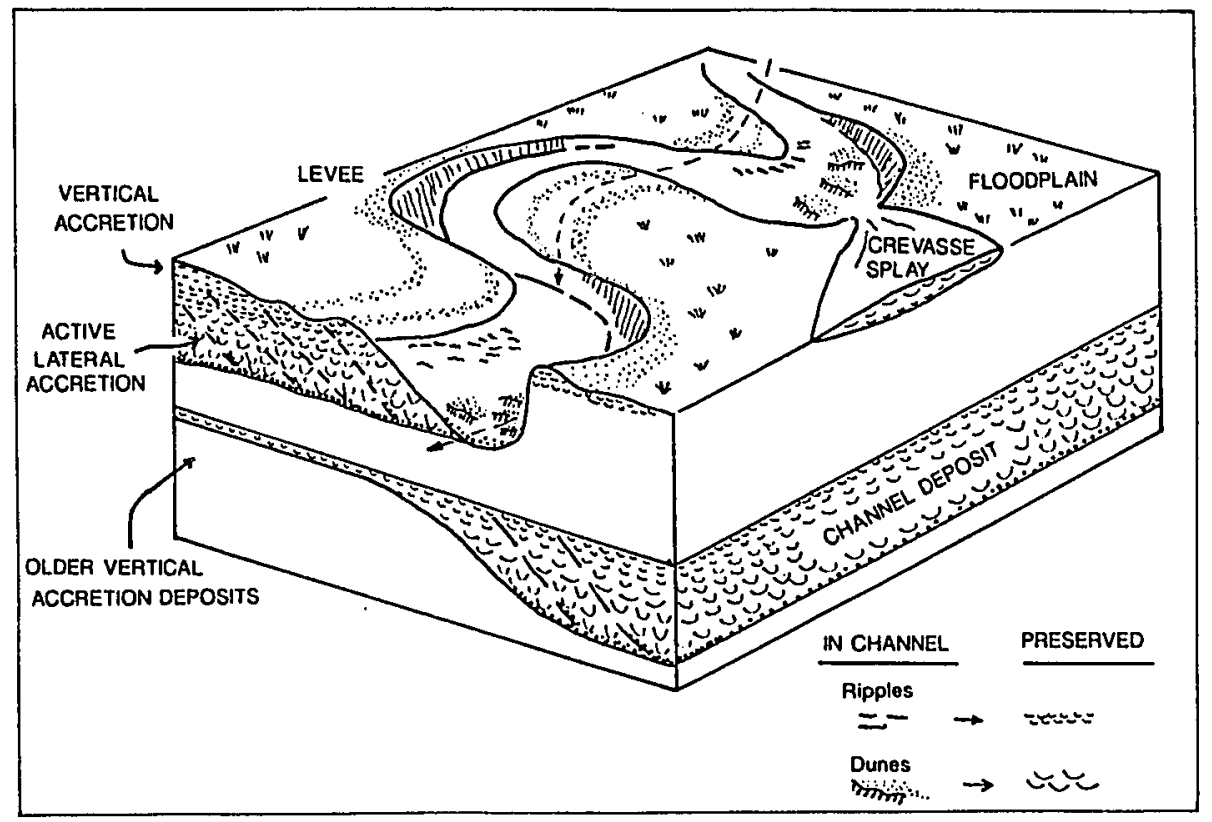

Figure 17. Diagram of subenvironments in a meandering river setting (modified from Walker and Cant, 1984). 
sandstones that lack cross-stratification probably are mostly levee deposits. Thin-bedded sandstones that have cross-stratification are interpreted as crevasse splay deposits.

The levee sandstones formed when flooding overtopped the channel banks (Singh, 1972). They generally are ripplestratified and bioturbated, and they accumulated as thin sheets of sand that stretched out laterally along the flanks of the channel in areas of low velocity flow at flood stage. The crevasse splay sandstones were deposited where the banks of the stream were breached (Smith, 1983; Tyler and Ethridge, 1983). Some crevasse splay sandstones display ripple-stratification at the base and cross-stratification above, suggesting that the breach became larger and the resulting flow velocity increased with time.

\section{Claystone and Siltstone Lithofacies}

Deposition of the claystone and siltstone lithofacies occurred at low flow velocities on a floodplain. Plant roots probably are responsible for the mottled appearance and lack of stratification of the clay and silt. Where gray, the color demonstrates that the floodplain environment was somewhat reducing (Helm, 1985). 
Coal and Carbonaceous Shale Lithofacies

Coal and carbonaceous shale formed by deposition of peat within a swamp environment. The swamps probably occurred within floodplain depressions that flanked the channels (weimer, 1976). The proportion of organic matter in coal and carbonaceous shale reflects variations in the character of the swamps.

The coal formed in situ by accumulation of plant material within a poorly drained swamp where the groundwater table remained high and in balance with the depositional surface (Weimer, 1976). In order to retain coal swamp conditions, there must have been very little influx of stream water (Beaumont, 1979).

The carbonaceous shale formed by deposition of plant material with clay and silt, probably on the fringes of a poorly drained swamp. In a study of the Fort Union Formation of the sand Wash basin, Beaumont (1979) inferred that deposition of carbonaceous shale occurred within the transition between well-drained and poorly drained swamps. In such an environment, bacterial degradation of organic matter is greater than in the poorly drained swamp, and siliciclastic material mixes with plant material to produce carbonaceous shale (Weimer, 1976). 
Limestone Lithofacies

The limestone lithofacies has multiple origins. Some of the limestones formed in ponds on a floodplain. Whereas others may have developed by replacement of organic material.

Many of the limestones in the Wasatch Formation are biomicrites that formed by accumulation of shelled organisms and fine-grained lime mud in floodplain ponds (Hanley, 1976). The micritic limestones in the Wasatch Formation probably also have a pond origin, but they lack the coarse bioclasts present in the biomicrites. The ponds in which the limestone formed probably developed in areas of the floodplain that were cut off from influx of clastic detritus (Helm, 1985).

Although some micritic limestones in the Fort Union Formation probably formed in floodplain ponds, many sandy micrites may have originated by replacement of organic material. The lack of internal stratification and limited lateral extent of these unfossiliferous, pod-like limestones make them likely candidates for a replacement origin. Kraus (1988), in her study of calcareous pods in the Fort Union and Willwood formations of the Bighorn basin, suggested that they formed by replacement of tree stumps in microbe-rich soil. Tree trunk shapes have not been recognized in Fort Union carbonates of the Green River basin, but replacement 
within a soil is a possible mode of origin. 
FLUVIAL ARCHITECTURE AND BASIN SUBSIDENCE

In order to relate fluvial architecture to the subsidence of the basin, the variations in architecture and thickness are displayed using cross-sectional panels and isopachous maps.

\section{Description}

Fluvial Architecture

The fluvial architecture of each field area was analyzed by study of panels constructed to show the channel sandstone distribution (Plates I and II). Each panel depicts the well-exposed portion of the field area and the channel sandstone bodies and interchannel deposits exposed within the area of outcrop. From the panels, channel sandstone density and connectedness were calculated for the outcrop area.

Panels were constructed from measured sections that were correlated using interchannel sandstones, limestones, or coal beds. If none of the interchannel deposits could be traced laterally, channel sandstones were used for correlation. Correlation was accomplished by following individual beds in the field.

The completed panel shows where sections were measured, and channel sandstones are depicted with the surrounding 
floodplain deposits. Interchannel beds that were used to correlate between measured sections also are shown on the panels. All other interchannel sandstones, mudstones, coal and limestones are grouped as interchannel deposits. Each panel also shows a line that separates well exposed from poorly exposed portions of the field area.

The panels were analyzed to determine the concentration of channel sandstones within the interchannel deposits. This was accomplished by determining the combined area of all of the channels in the panel and comparing this with total area of the outcrop. The residual area density is defined as the cumulative area of channel sandstones divided by the total panel area (Allen, 1978).

The connectedness of channels also was determined for each panel from the length of the line surrounding all of the channel sandstones. The connectedness index is defined as the cumulative length of line shared between channels that are connected divided by the total line length around all channels. The residual area density and connectedness index for each field area are summarized in Figure 18.

Plate I contains the panel for field area I. Because the Fort Union Formation and the upper portion of the Wasatch Formation are discontinuously exposed in area $I$, the panel covers only the lower $174 \mathrm{~m}$ of the Wasatch Formation. This panel represents a cross-section perpendicular to an 


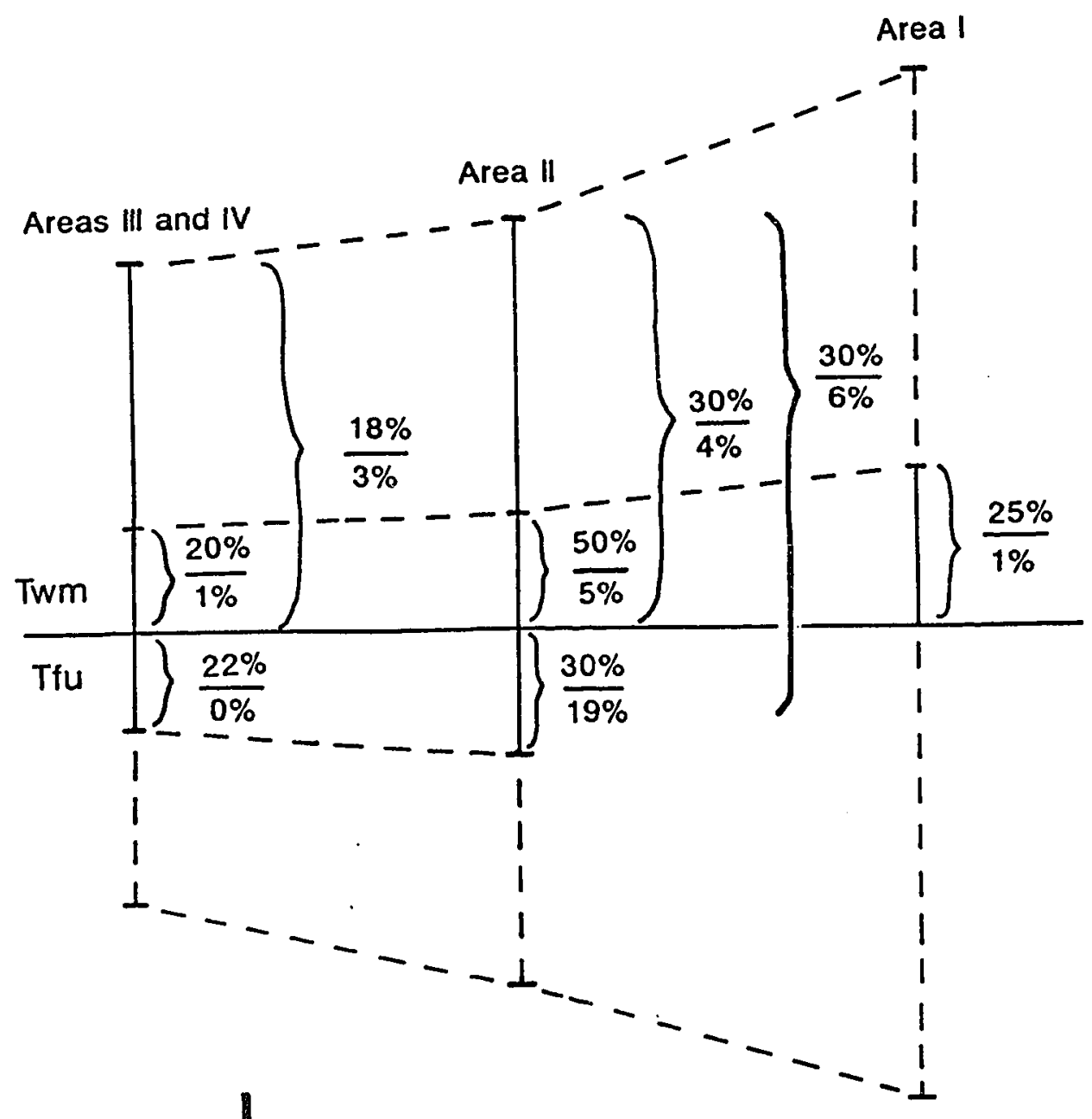

$100 \mathrm{~m}$

Figure 18. A summary of the channel density (upper number) and connectedness index (lower number) for each field area. The solid vertical lines represent stratigraphic intervals that are depicted in the panels and that have some comparison interval in another field area. Dashed vertical lines represent stratigraphic thickness that is not depicted on the panels or that has no other interval for comparison. 
crossbed orientations, the vectoral average paleocurrent direction for area $I$ is N68E (fig. 19) Area I has a channel area density of $25 \%$ and a connectedness index of $1 \%$. The distribution of channel sandstones is relatively uniform with no discernible vertical change in channel density. The fluvial architecture of field area II is summarized in Plate I. The Wasatch Formation is well exposed throughout, but only the upper $139 \mathrm{~m}$ of the Fort Union Formation is well exposed. For area II, the paleocurrent average from 97 measurements is $571 \mathrm{E}$, and the panel was projected perpendicular to that at an orientation of N19E. The residual area density of channels is approximately $30 \%$, and the connectedness index is about $6 \%$. For the Fort Union Formation, the channel density is $30 \%$, and the connectedness index is 19\%. For the Wasatch Formation, the channel density is $30 \%$, and the connectedness index is $4 \%$. The thickness of an interval of the lower Wasatch Formation approximately correlative with the $174 \mathrm{~m}$ exposed at field area I was. calculated by multiplying $174 \mathrm{~m}$ by the ratio of Wasatch formation thicknesses for the two areas as determined by Roehler (1973a, 1973b). The thickness of this stratigraphic interval in area II is $130 \mathrm{~m}$; for this interval the area density is 50\%, and the connectedness index is $5 \%$.

The panel for field area II depicts a high channel 

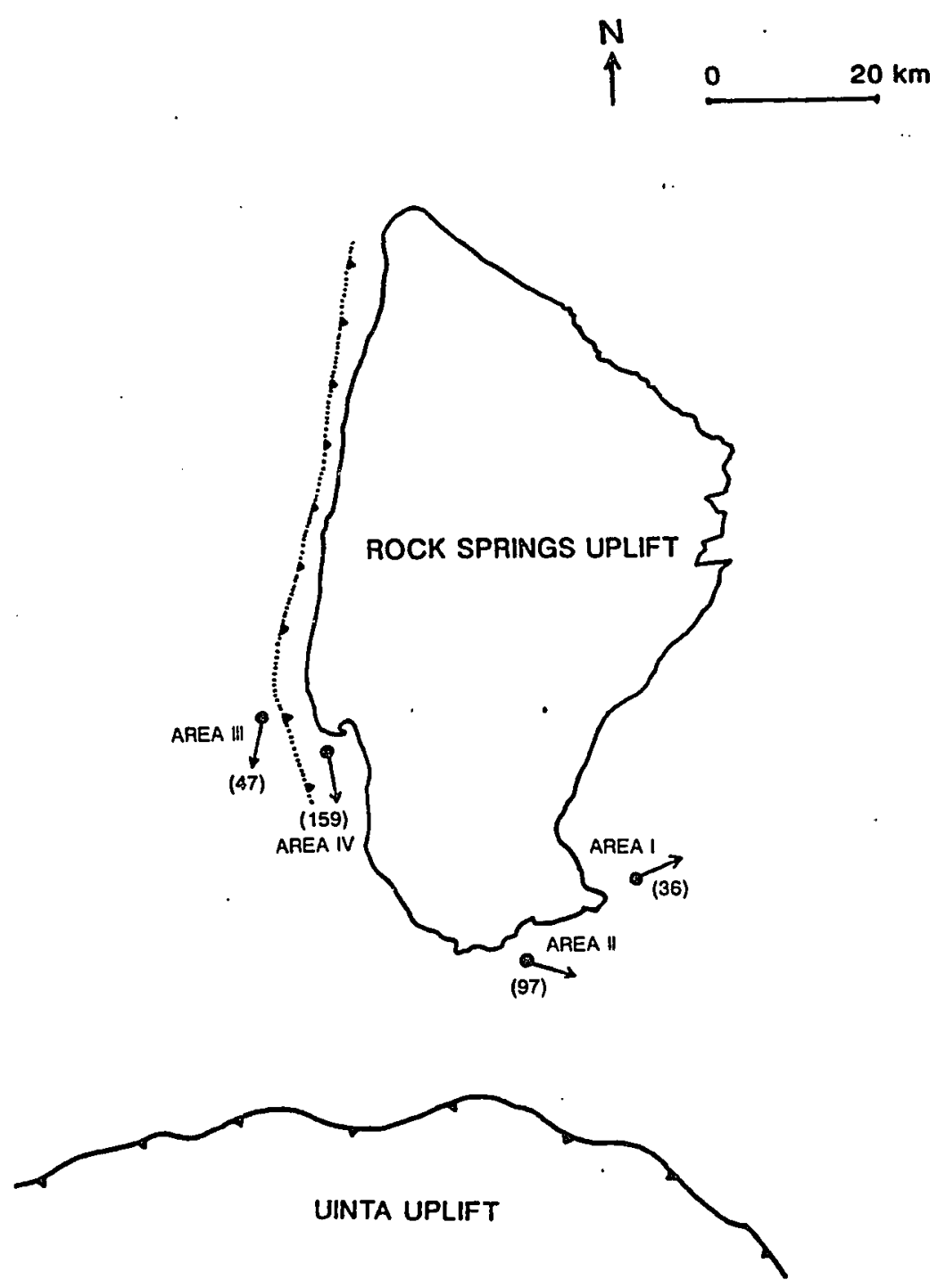

Figure 19. Map summarizing the paleocurrent averages for the four field areas. The number of paleocurrent measurements is shown in parentheses. 
sandstone density near the base of the Wasatch Formation and decreasing density upwards. As the percentage of channel sandstone decreases, the amount of limestone and coal increases.

Field areas III and IV represent closely spaced exposures of different stratigraphic levels. Field area IV covers only the Fort Union Formation, and field area III is entirely within the Wasatch Formation. The full thickness of both formations is exposed, but the exposure in area IV occurs as three subareas of continuous outcrop separated by covered intervals and correlated by persistent coal beds.

For field areas III and IV, placement of the Paleocene - Eocene boundary is complicated, because it apparently lies within the Wasatch Formation (Rirschbaum and Nelson, 1988). Without more precise age resolution, the mapped formation boundary is the closest available approximation of the Paleocene - Eocene boundary, and the mapped formation boundary is here used for comparison with other field areas.

The panel for field area IV (Plate II) was modified from Kirschbaum (1987). Sandstone body geometry was adapted from the published panel, and the limit of outcrop was more rigorously constrained. The vector mean of 159 paleocurrent measurements is S9E (Kirschbaum, 1987), and the panel was projected to an orientation of N81E. 
The uppermost $105 \mathrm{~m}$ of the Fort Union interval at area IV is approximately equive:...t to the Fort Union rocks in area II. For this intervil, the residual area density is $22 \%$ and the connectedness index is zero.

Plate II also contains the panel for field area III. The vectoral average of 47 paleocurrent measurements in area III is $\mathrm{s} 12 \mathrm{~W}$, so the panel was constructed as a crosssectional projection at S78E. Analysis of the panel shows that the residual area density of channels is $18 \%$ and connectedness index is $3 \%$.

The lower $116 \mathrm{~m}$ of Wasatch Formation in field area III is approximately equivalent to the section exposed in field area I. This portion has a residual area density of $20 \%$ and a connectedness index of $1 \%$. Although the channel density is greatest at the base of the Wasatch, the upward decrease is very small.

\section{Thickness}

Figure 20 shows the total thickness of the Fort Union and Wasatch formations and the Luman Tongue of the Green River Formation in the field areas. Field areas $I$ and II are shown separately and areas III and IV are combined. This stratigraphic interval is thinnest in areas III and IV, has an intermediate thickness in area II, and is thickest in area $I$. 

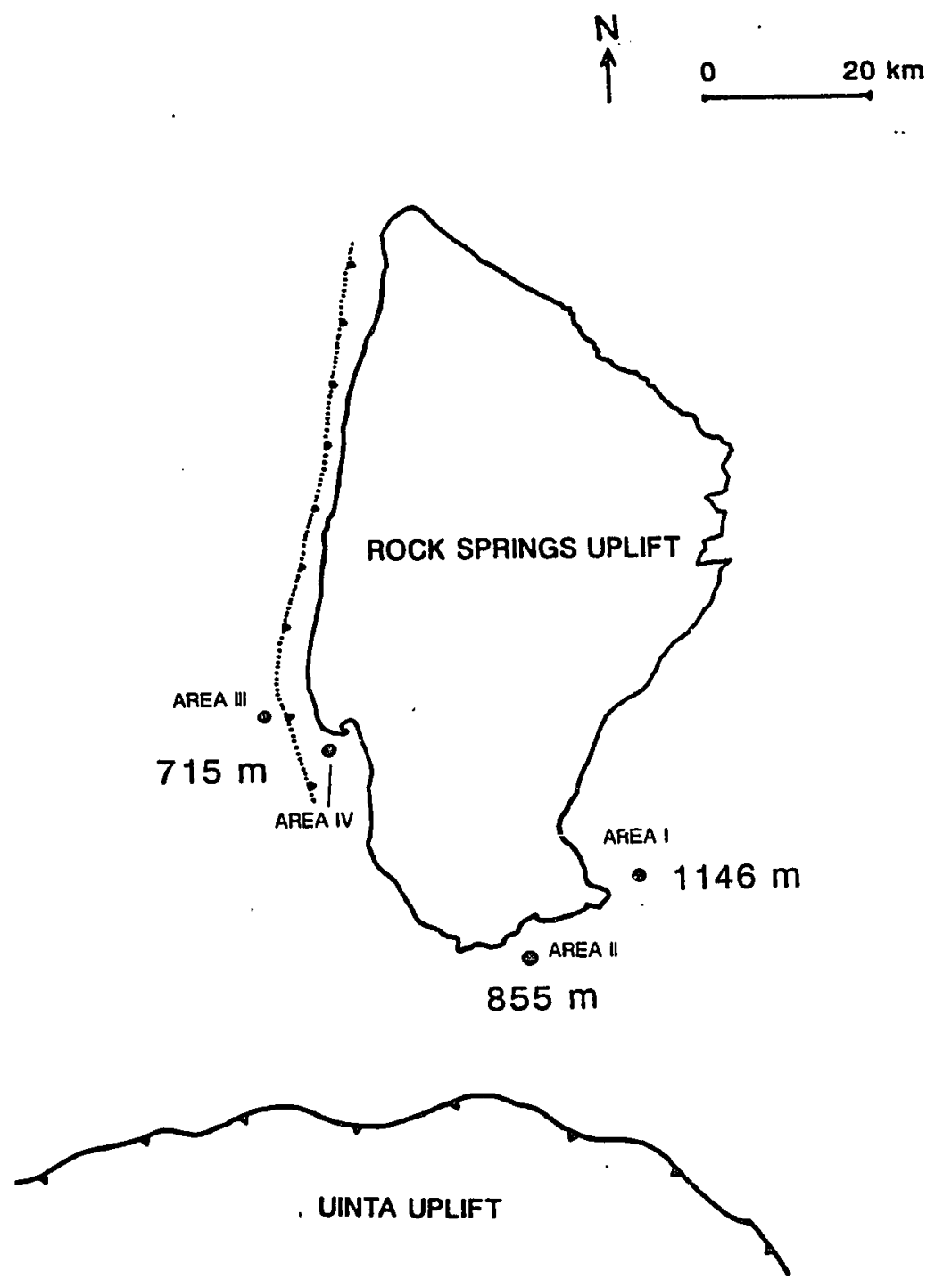

Figure 20. Map showing the combined thickness of the Fort Union and Wasatch formations and Luman Tongue of the Green River Formation in field areas I through IV. Data are from this study and from Roehler (1973a, 1973b, 1973c) and Kirschbaum (1987). 
Additional thickness data were compiled from published measured sections and interpreted well logs to produce an isopach map of the southern Green River basin near the Rock Springs uplift (fig. 21). The isopach map depicts the combined thicknesses of the Wasatch and Fort Union formations and the Luman Tongue of the Green River Formation.

The purpose of compiling thickness data is to allow a comparison of thickness over the same time interval for different portions of the basin. Roehler (1981) showed that the upper boundary of the Luman Tongue retains a relatively fixed stratigraphic position even though the unit thickens southward. This boundary also is relatively easy to pick from electric logs (Sullivan, 1980), so this is a suitable upper boundary for the stratigraphic interval displayed in Figure 21. The Lysetian - Lost Cabinian boundary falls within the Luman Tongue (Sklenar and Andersen, 1985), and this boundary has an age of approximately $52 \mathrm{Ma}$ (West and others, 1987). The upper boundary of the Luman Tongue is inferred to be slightly younger than $52 \mathrm{Ma}$. The age of the base of the Fort Union Formation is similar at all exposures around the Rock springs uplift (Kirschbaum and Nelson, 1988). Kirschbaum and Nelson (1988) showed that the base of the Fort Union Formation at the Rock springs uplift is within the third Paleocene palynomorphic 


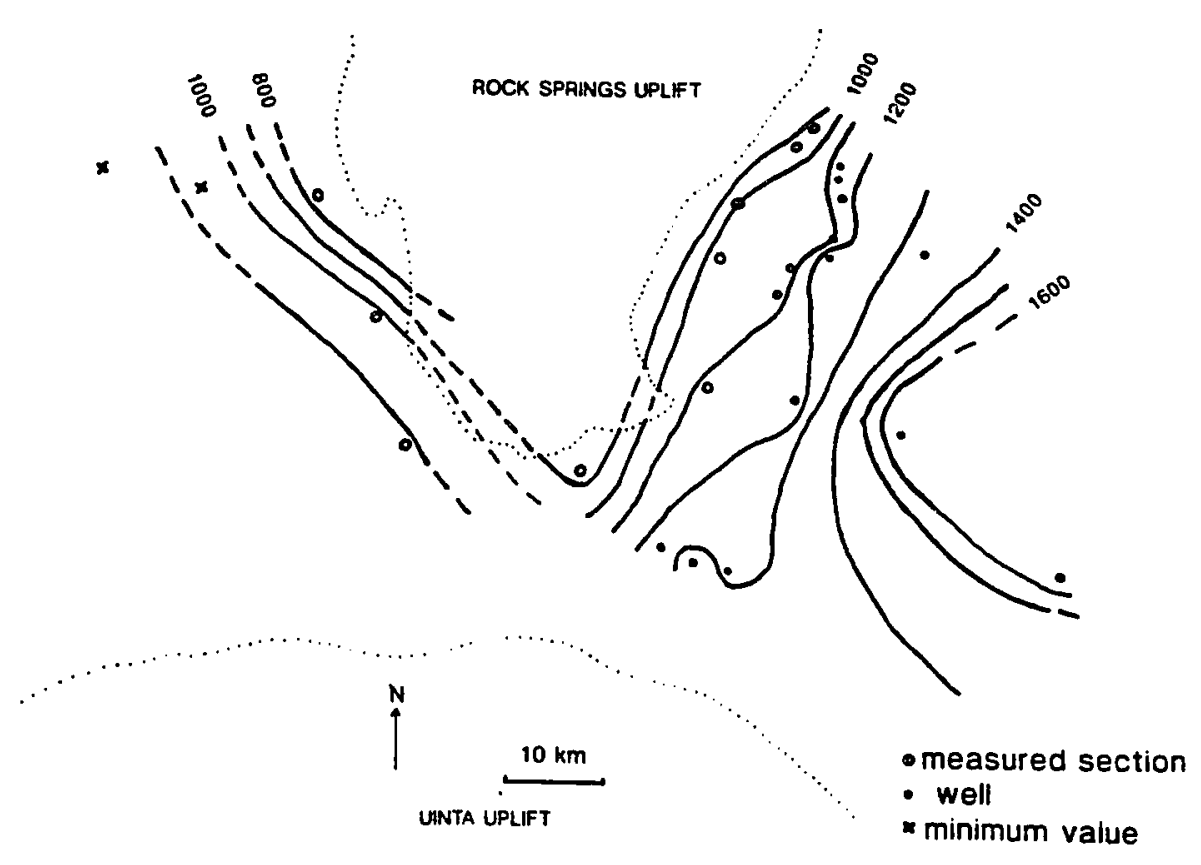

Figure 21. Isopach map of the Fort Union and Wasatch Formations and Luman Tongue of the Green River Formation in the southern Green River basin near the Rock Springs uplift. Thicknesses are from this study and Roehler (1961, 1965, $1973 \mathrm{a}, 1973 \mathrm{~b}, 1973 \mathrm{c}, 1974 \mathrm{a}, 1974 \mathrm{~b}, 1974 \mathrm{c}, 1974 \mathrm{~d}, 1977$, 1979a, 1979b), Colson (1969), Law and others (1979), Tyler (1980), Bader and others (1982), and Kirschbaum (1987). Dotted lines depict the limit of Cretaceous outcrop from Love and Christiansen (1985). Dashed isopachs are interpolated or projected. 
zone of Nichols and ott (1978). However, in the eastern Washakie sub-basin, near the town of Baggs, Wyoming, the base of the Fort Union Formation is older and falls within the second palynomorphic zone ( $R$. Hettinger, personal communication, 1989).

At the onset of Fort Union deposition, onlap onto the Rock springs uplift may have occurred. The amount of time represented by this onlap can be constrained from land mammal ages. The base of the Fort Union Formation at the Rock springs uplift is within the Torrejonian land mammal stage (winterfeld, 1982). This means that the lower boundary is older than $61 \mathrm{Ma}$ (Butler and others, 1987). Perhaps the oldest Paleocene rocks in the basin are in the northern Green River basin (Shuster and Steidtmann, 1988). The age at the base of these rocks is upper Dragonian, close to $64 \mathrm{Ma}$.

The Fort Union - Wasatch - Luman stratigraphic interval at the Rock springs uplift represents approximately nine million years of deposition. In the northern Green River basin, an additional three million years may be represented. Therefore, approximately thirty percent of the thickening away from the Rock springs uplift may be the result of onlap. Because the Fort Union is only one palynomorphic zone older in the Washakie sub-basin than on the Rock springs uplift, the thickening resulting from onlap from the 
adjacent sub-basins probably is less than thirty percent.

Along the west flank of the Rock Springs uplift, this stratigraphic interval thickens from field areas III and IV southward. On the east flank of the uplift, thickness also increases southward. On the south flank, thicknesses seem to decrease toward the axis of the uplift.

The Fort Union, Wasatch and Luman can be traced into the subsurface east and west of the Rock springs uplift. In the Washakie sub-basin east of the uplift, there is an abundance of well log data. The subsurface data show a marked increase in thickness basinward, away from the uplift. West of the uplift, in the Bridger sub-basin, sparse subsurface data indicate a thickening westward. Based upon subsurface data, Tyler (1980) reported that the Fort Union Formation thickens westward from $320 \mathrm{~m}$ along the south flank of the uplift to $990 \mathrm{~m}$ in the Bridger sub-basin.

\section{Interpretation}

The paleocurrent averages for the field areas (fig. 19) fit a paleogeographic reconstruction in which rivers flowed southward from the Wind River uplift and carried sediment toward a topographic axis near the southern margin of the basin (Baldwin and Andersen, 1987; Rirschbaum and others, 1988; Tollestrup and Steidtmann, 1990). Areas III and IV 
represent deposition by southward-flowing tributary rivers, whereas areas I and II fall within the eastward-flowing trunk river system along the basin axis. This asymmetry probably resulted from spatial differences in subsidence rate.

Thickness variations across the basin may relate to subsidence. Thicknesses along the flanks of the uplift seem to increase southward, toward the basin axis, and the field areas in the basin axis have greater thicknesses than the northern areas. The Luman Tongue also thickens southward and is confined to the southern portion of the basin. This indicates that the basin axis was located in the region of most rapid subsidence.

The fluvial architecture of these rocks also varies with regard to paleogeographic location. The northernmost field areas, III and IV, display the widest spacing of channels. Those areas within the axis trunk river system, areas I and II, have a closer spacing of channels. Rapid subsidence combined with high channel density in the basin axis indicates that the alluvial plain of the trunk river system was constricted. In the northern field areas, lower values of channel density probably resulted from a wide, unconfined alluvial plain. The southern Green River basin appears to fit the model of an asymmetrically subsiding basin proposed by Bridge and Leeder (1979) and Alexander and 
Leeder (1987), because the greatest channel sandstone density occurs in the area of greatest subsidence.

The confinement of the trunk river system alone does not explain the striking variation in thickness and architecture from east to west along the basin axis. In the lower Wasatch of area $I$, the residual area density is about 25\%, but the same interval in area II has a residual area density of 50\%. This contrast in architecture along the basin axis may reflect variations in subsidence rate, frequency of avulsion, or width of the alluvial plain.

Differences in channel spacing at field areas $I$ and II possibly reflect subsidence variations along the basin axis, because stratigraphic thickness also differs along the axis. Greater thickness and lower channel density at area I may reflect more rapid subsidence than in area II. Slow subsidence at area II may indicate the influence of the Rock Springs uplift, because area II is closer to the axis of the uplift, and it subsided more slowly than off-axis field areas.

On the isopach map (fig. 21), the Rock springs uplift is an area of stratigraphic thinning within the basin, and it is interpreted as an area of minimum subsidence. If subsidence was controlled solely by the load from the Uinta Mountains uplift, an isopach map would show a consistent thickening southward. Figure 21 displays both this 
southward thickening and thinning toward the center of the Rock Springs uplift.

Two hypotheses explain slow subsidence at the Rock springs uplift. In one, differences in subsidence rate could resuit from variations in crustal thickness within the subsiding basin. An alternative hypothesis requires an active Rock Springs uplift during Fort Union and Wasatch deposition.

In the first hypothesis, pre-Fort Union thrusting on the fault that bounds the Rock springs uplift caused crustal thickening at the center of the basin. Differential subsidence is possible even if the fault was not active during deposition of the Fort Union and Wasatch formations. Flexure in response to the Uintan load was possibly slower at the thickened Rock springs uplift region than was flexure of the adjacent unthickened crust, because the flexure of a basin under an applied load is partially controlled by the thickness of the lithosphere (Beaumont, 1981). The observed variations in stratigraphic thickness may reflect differences in subsidence rate, and subsidence rate may be, in part, a function of crustal thickness.

Alternatively, slow subsidence rates at the Rock Springs uplift could have resulted from active uplift. Continuing relative movement on the fault bounding the Rock Springs uplift may have caused continued uplift at the basin 
center.

If the rate of uplift was less than the rate of subsidence, a buried Rock springs uplift could have developed at the basin center. Fluvial sediments may have covered the uplift, but were thinner there than in other parts of the basin.

Overall, subsidence could have exceeded uplift, but periods of particularly rapid uplift or slow subsidence could have produced local unconformities. On the east flank of the uplift, Roehler (1979a) interpreted fossil soils within the Fort Union Formation as unconformities. These fossil soils may represent periods when local uplift exceeded basin subsidence.

If uplift exceeded subsidence, the Rock Springs uplift may have been topographically expressed, and thus it would have been the site of erosion or non-depostion within the basin. Although considerable subsidence occurred along the flanks of the uplift, a topographically expressed Rock Springs uplift could explain the observed patterns of thickness and fluvial architecture.

Roehler (1961) explained the presence of red beds on the west flank of the Rock springs uplift as evidence of topographic expression during the Eocene. Kirschbaum and Nelson (1988) showed that these red beds formed during later diagenesis and did not necessarily provide evidence of a 
topographic highland within the basin center. Transport of Wind-River-derived sediment across the Rock Springs uplift suggested to Kirschbaum and others (1988) that the uplift was not topographically high during Paleocene and Eocene time.

Whether the Rock springs uplift was topographically expressed or not, stratigraphic thinning demonstrates that it was a region of slow subsidence. Either thickening of the crust from pre-middle Paleocene thrusting or active uplift during the Paleocene and Eocene could explain this slow subsidence, and both processes could have operated together to produce the observed variations in stratigraphic thickness and channel density.

A second control on channel density is avulsion. The frequency of avulsion is largely controlled by the sand-tomud ratio within the system (Cant, 1982). A high proportion of muddy, fine-grained sediment will cause a river to build a cohesive bank that is more resistant to erosion than a sandy bank. If the river is confined by a sandy bank, the stream is more likely to erode the bank and break out of its channel.

Around the flanks of the Rock springs uplift, the Fort Union and Wasatch formations show little variation in grain size distribution. The basin-center facies contains very little conglomerate, and channel sandstones are mostly 
medium-grained with only minor coarse- or fine-grained sandstone. The interchannel lithofacies are predominantly mudstores with interbedded medium- to fine-grained sandstones. The preserved record reflects a very steady fluvial system with a very uniform grain size distribution and sand-to-mud ratio. Avulsion frequency is unlikely to have changed noticeably as a result of a shift in grain size distribution.

A third possible mechanism responsible for the crowded architecture at area II is a narrowing of the basin axis south of the Rock springs uplift, which could have restricted the lateral range of the trunk river there. This constriction may have occurred between alluvial fans building northward from the Uinta Mountains uplift (Wray, 1988) and either the sloping surface of sediment derived from the Wind River Mountains uplift or a topographically expressed core of the Rock springs uplift. In either case, a narrowing of the basin axis only explains the observed fluvial architecture and not the variations in thickness that resulted from subsidence variations.

Taken together, differences in thickness and fluvial architecture along the basin axis suggest that subsidence was slowest where this axis crossed the southern end of the Rock springs uplift. This requires that the uplift was active or was resistant to flexure during subsidence of the 
basin. Alternatively, both processes may have acted together to slow subsiance above the uplift. Channel density also varied along the basin axis either in response to subsidence variations or possibly because of constriction of the basin axis resulting from topographic expression of the Rock springs uplift.

Most of the evidence indicates that the Rock Springs uplift was active but covered by sediment during deposition Fort Union and Wasatch formations. Active uplift could produce the unconformities described by Roehier (1979a). Thrusting along the margin of the Rock springs uplift occurred both before and after deposition of the Fort Union and Wasatch formations; therefore, it is likely that it also occurred during deposition. Paleocurrent data collected from the Fort Union and Wasatch formations on the flanks of the Rock springs uplift indicate that sediment was transported over the Rock Springs uplift toward the basin axis (Baldwin and Andersen, 1987; Rirschbaum and others, 1988), and the sediment could have covered the uplift.

The Rock springs uplift was probably active during deposition of the Fort Union and Wasatch Formations, and subsidence of the basin was caused by loading from the Uinta Mountains. If this is correct, the north-south striking Rock springs uplift was active at the same time as the eastwest striking Uinta uplift, and this indicates that these 
variousiy oriented uplifts responded to the same stresses at the same time. 


\section{CONCLUSIONS}

The Paleocene Fort Union and Eocene Wasatch formations of the southern greater Green River basin are fluvial sedimentary rocks deposited in a flexurally subsiding basin during the Laramide orogeny. Thrust loading from the Uinta Mountains uplift on the southern margin of the basin caused subsidence that allowed sediment to be carried southward from the Wind River Mountains uplift, via southward-flowing rivers, to an eastward-flowing trunk river system in the rapidly subsiding basin axis.

Both formations contain five distinct lithofacies: massive sandstone; thin-bedded ripple-stratified sandstone; claystone and siltstone; coal and carbonaceous shale; and limestone. The massive sandstones contain crossbeds that diminish in scale upward to ripple stratification, and they fine upward from coarse- or medium-grained to fine- and very fine-grained sandstone. Numerous, parallel to subparallel, low-angle stratification surfaces extend through the sandstones and truncate the crossbed sets. These sandstones are interpreted as river channel deposits that formed by lateral accretion in a meandering river system. Other lithofacies are interpreted as floodplain and overbank deposits.

The distribution of channel sandstones in interchannel deposits and combined stratigraphic thickness of the Fort 
Union and Wasatch formations and Luman Tongue of the Green River Formation in four field areas show considerable variation across the basin. Rocks of the two northern field areas on the west flank of the Rock springs uplift formed within a southward-flowing tributary river system, and field areas on the southern and southeastern flanks of the uplift were situated within an eastward-directed basin-axis river. The lowest channel density and stratigraphic thinning occur in the northern field areas. Thickness is intermediate and channel density is greatest on the south flank of the Rock Springs uplift. Thickness is greatest and channel density is intermediate in the field area on the southeast flank. Isopach maps also show increasing thickness southward toward the Uinta Mountains and stratigraphic thickening both east and west of the Rock springs uplift.

Channel sandstone density was controlled by the subsidence rate and width of the alluvial plain. The low channel density and stratigraphic thinning in the northern field areas are inferred to have resulted from the wide alluvial plain of the southward-flowing rivers combined with relatively slow subsidence. The basin axis has a greater thickness and higher channel density, resulting from rapid subsidence combined with a narrow alluvial plain. Differences in thickness and channel density within the basin axis result from differences in stbsidence rate. 
Thinning of the sequence toward the axis of the Rock springs uplift indicates that the uplift was the site of minimum subsidence within the basin.

Either of two hypotheses could explain the subsidence minimum at the Rock springs uplift. In the first, thrusting along the margin of the uplift caused crustal thickening before Fort Union and Wasatch deposition. This zone of thickened crust may have been resistant to flexure under the load of the Uinta Mountains. Alternatively, the Rock Springs uplift bounding fault may have been active during subsidence of the basin, and relative uplift combined with subsidence could have produced a subsidence minimum or topographically expressed uplift. An active uplift at the basin center possibly also caused constriction of the basin axis alluvial plain on the south flank of the uplift. Unconformities within the Laramide sequence indicate that the uplift was active, and paleocurrent data show that sediment was transported over the uplift. Present evidence is compatible with either hypothesis, and it is possible that both mechanisms operated simultaneously. The data presented here seem most consistent with the hypothesis that the Rock springs uplift was active but covered by sediment during deposition of the Fort Union and Wasatch formations. Laramide fluvial sedimentation in the southern Green River basin reflects the interplay of subsidence, floodplain 
width, and internal tectonism. 
REFERENCES CITED

Alexander, Jan, and Leeder, M. R., 1987, Active tectonic control on alluvial architecture, in Ethridge, F. G.. Flores, R. M., and Harvey, M. D., eds., Recent developments in fluvial sedimentology: Society of Economic Faleontologists and Mineralogists special Publication 39, p. 243-252.

Allen, J.R. L., 1970, studies in fluviatile sedimentation: a comparison of fining upwards cyclothems with special reference to coarse member interpretation: Journal of Sedimentary Petrology, v. 40, p. 298-323.

Allen, J. R. L., 1978, Studies in fluviatile sedimentation: an exploratory quantitative model for the architecture of avulsion-controlled alluvial suites: Sedimentary Geology, v. 21, p. 129-147.

Allen, J. R. L., 1983, Studies in fluviatile sedimentation: bars, bar-complexes and sandstone sheets (low sinuosity braided streams) in the Brownstones (L. Devonian), Welsh Borders: Sedimentary Geology, v. 33, p. 237-293.

Bader, J. W., Law, B. E., and spencer, C. W., 1982, Preliminary chart showing electric log correlations, section $D-D^{\prime}$ of some upper Cretaceous and Tertiary rocks, Green River basin, Wyoming: U. S. Geological Survey Open File Report 82-129.

Baldwin, R. J., and Andersen, D. W., 1987, Eocene sediment dispersal pattern records asymmetry of Laramide Green River basin, southwestern Wyoming (abs.): American Association of Petroleum Geologists Bulletin, v. 71 , p. 527 .

Beaumont, C., 1981, Foreland basins: Geophysical Journal of the Royal Astronomical Society, v. 65, p. 291-329.

Beaumont, E. A., 1979, Depositional environments of Fort Union sediments (Tertiary northwest Colorado) and their relation to coal: American Association of Petroleum Geologists Bulletin, v. 63, p. 194-217. 
Beck, R. A., Vondra, C. F., Filkins, J.E., and Olander, J. D., 1988, Syntectonic sedimentation and Laramide basement thrusting, Cordilleran foreland; Timing of deformation, in schmidt, C. J., and Perry, W. J., eds., Interaction of the Rocky Mountain foreland and Cordilleran thrust belt: Geological society of America Memoir 171, p. 465-487.

Bird, P., 1984, Laramide crustal thickening in the Rocky Mountain foreland and Great Plains: Tectonics, v. 3, p. 741-758.

Blakey, R. C., and Gubitosa, R., 1984, Controls of sandstone body geometry and architecture in the Chinle Formation (Upper Triassic), Colorado Plateau: Sedimentary Geology, v. 38, p. 51-86.

Bown, T. M., and Kraus, M. J., 1981, Lower Eocene paleosols (Willwood Formation, northwest wyoming, U.S.A.) and their significance for paleoecology, paleoclimatology, and basin analysis: Palaeogeography, Palaeoclimatology, Palaeoecology, v. 34, p. $1-30$.

Bradley, W. H., 1964, Geology of Green River Formation and associated rocks in southwestern wyoming and adjacent parts of Colorado and Utah: U. S. Geological Survey Professional Paper 496-A, P. A1-A84.

Brewer, J. A., Smithson, S. B., Oliver, J. E., Raufman, S., and Brown, L. D., 1980, The Laramide orogeny: evidence from COCORP deep crustal seismic profiles in the Wind River Mountains, Wyoming: Tectonophysics, v. 62, p. 165-189.

Bridge, J. S., and Leeder, M. R., 1979, A simulation model of alluvial stratigraphy: Sedimentology, v. 26, p. 617-644.

Brown, R. W., 1949, Paleocene deposits of the Rocky Mountains and Great Plains: U.S. Geological Survey, Preliminary Map, scale 1:1,000,000.

Brown, W. G., 1988, Deformation style of Laramide uplifts in the Wyoming foreland, in Schmidt, C. J., and Perry, W. J., eds., Interaction of the Rocky Mountain foreland and Cordilleran thrust belt: Geological society of America Memoir 171, p. 1-25. 
Butler, R. F., Krause, D. W., and Gingerich, P. D., 1987, Magnetic polarity stratigraphy and biostratigraphy of middle-late Paleocene continental deposits of southcentral Montana: Journal of Geology, v. 95, p. 647657 .

Cant, D. J., 1982, Fluvial facies models and their application, in Scholle, P.A., and spearing, D., eds., Sandstone depositional environments: American Association of Petroleum Geologists Memoir 31, p. 115-137.

Colson, C. T., 1969, Stratigraphy and production of the Tertiary formations in the Sand Wash and Washakie basins: Wyoming Geological Association, 21st Annual Field Conference Guidebook, p. 121-128.

Compton, R. R., 1985, Geology in the field: New York, John Wiley and Sons, $398 \mathrm{p}$.

Coney, P. J., 1978, Mesozoic - Cenozoic Cordilleran plate tectonics, in Smith, R. B., and Eaton, G. P., eds., Cenozoic tectonics and regional geophysics of the western Cordillera: Geological Society of America Memoir 152, p. 33-50.

Dickinson, W. R., Klute, M. A., Hayes, M. J., Janecke, S. U., Lundin, E. R., McRittrick, M. A., and Olivares, M. D., 1988, Paleogeographic and paleotectonic setting of Laramide sedimentary basins in the central Rocky Mountain region: Geological society of America Bulletin, v. 100, p. 1023-1039.

Garing, J. D., and Tainter, P. A., 1985, Greater Green River basin regional seismic line, in Gries, R. R., and Dyer, R. C., eds., Seismic exploration of the Rocky Mountain region: Denver, Rocky Mountain Association of Geologists and Denver Geophysical Society, p. 233-238.

Goddard, E. N., Trask, P. D., DeFord, R. R., Rove, O. N., Singewald, J. T., and overbeck, R. M., 1951, Rock Color Chart: Boulder, Geological Society of America, $18 \mathrm{p}$.

Gries, R., 1983a, Oil and gas prospecting beneath Precambrian of foreland thrust plates in the Rocky Mountains: American Association of Petroleum Geologists Bulletin, v. 67, p. 1-28. 
Gries, R., 1983b, North-south compression of Rocky Mountain foreland structures, in Lowell, J. D., ed., Rocky Mountain foreland basins and uplifts: Denver, Rocky Mountain Association of Geologists, p. 9-32.

Hagen, E. S., Shuster, M. W., and Furlong, K. P., 1985, Tectonic loading and subsidence of intermontane basins, Wyoming foreland province: Geology, v. 13, p. 585-588.

Hanley, J. H., 1976, Paleosynecology of nonmarine Mollusca from the Green River and Wasatch formations (Eocene) southwestern Wyoming and northwestern Colorado, in scott, R. W., and West, R. R., eds., structure and classification of paleocommunities: Stroudsburg, Dowden, Hutchinson, and Ross, Inc., p. 235-261.

Harms, J. C., Southard, J. B., and Walker, R. G., 1982, Structures and sequences in clastic rocks: Society of Economic Paleontologists and Mineralogists Short Course 9 .

Helm, R. L., 1985, Depositional history and petrology of the Fort Union Formation (Paleocene) southern flank of the Rock Springs Uplift, Sweetwater County, Wyoming [M.S. thesis]: San Jose, San Jose State University, 145 p.

Jordan, T. E., 1981, Thrust loads and foreland basin evolution, Cretaceous western United States: American Association of Petroleum Geologists Bulletin, v. 65, p. 2506-2520.

Reefer, W. R., 1965, Stratigraphy and geologic history of the uppermost Cretaceous, Paleocene, and lower Eocene rocks in the Wind River basin, Wyoming: U.S. Geological Survey Professional Paper 495-A, p. A1-A77.

Kirschbaum, M. A., 1987, Stratigraphic and sedimentologic framework of Paleocene rocks, southwest flank of the Rock Springs uplift, Sweetwater County, Wyoming: U.S. Geological Survey Map MF-1973, 2 sheets.

Kirschbaum, M. A., and Nelson, S. N., 1988, Geologic history and palynologic dating of Paleocene deposits, western Rock Springs uplift, Sweetwater County, Wyoming: Wyoming University Contributions to Geology, v. 26, p. 21-28. 
Kirschbaum, M. A., Andersen, D. W., Baldwin, R. J., and Helm, R. L., 1988, Paleocene drainage systems, Rock Springs uplift, Wyoming (abs.): Geological Society of America, Abstracts with Programs, v. 20, p. 424.

Kraus, M. J., 1988, Nodular remains of early Tertiary forests, Bighorn basin, Wyoming: Journal of Sedimentary Petrology, v. 58, p. 888-893.

Law, B. E., Spencer, C. W., and Roehler, H. W., 1979, Section $A-A^{\prime}$, surface and subsurface correlations of some upper Cretaceous and Tertiary rocks, Green River basin, Wyoming: U. S. Geological survey Open File Report 79-357.

Leeder, M. R., 1978, A quantitative stratigraphic model for alluvium, with special reference to channel deposit density and interconnectedness, in Miall, A. D., ed., Fluvial sedimentology: Canadian Society of Petroleum Geologists Memoir 5, p. 587-596.

Leeder, M. R., and Alexander, J., 1987, The origin and tectonic significance of asymmetric meander-belts: sedimentology, v. 34, p. 217-226.

Love, J. D., 1961, Definition of Green River, Great Divide, and Washakie basins, southwestern Wyoming: Bulletin of the American Association of Petroleum Geologists, v. 45, p. 1749-1755.

Love, J. D., and Christiansen, A. C., 1985, Geologic map of Wyoming: U.S. Geological Survey Map, scale 1:500,000, 3 sheets.

Masursky, Harold, 1962, Uranium-bearing coal in the eastern part of the Red Desert area, Wyoming: U. S. Geological Survey Bulletin 1099-B, p. B1-B149.

McKee, E. D., and Weir, G. W., 1953, Terminology for stratification and cross-stratification in sedimentary rocks: Geological Society of America Bulletin, v. 64, p. 381-389.

Miall, A. D., 1983, Basin analysis of fluvial sediments, in Collinson, J. D., and Lewin, J., eds., Modern and ancient fluvial systems: International Association of Sedimentologists special publication 6, p. 279-286. 
Miall, A. D., 1985, Architectural-element analysis: a new method of facies analysis applied to fluvial deposits: Earth Science Reviews, v. 22, p. 261-308.

Miall, A. D., 1988, Reservoir heterogeneities in fluvial sandstones: lessons from outcrop studies: American Association of Petroleum Geologists Bulletin, v. 72, p. 682-697.

Nichols, D. J., and Ott, H. L., 1978, Biostratigraphy and evolution of the Momipites - Caryopollenites lineage in the early Tertiary of the Wind River basin: Palynology, v. 2 , p. 93-112.

Picard, M. D., 1971, Classification of fine-grained sedimentary rocks: Journal of Sedimentary Petrology, v. 41, p. 179-195.

Picard, M. D., and Andersen, D. W., 1975, Paleocurrent analysis and orientation of sandstone bodies in the Duchesne River Formation (Eocene and Oligocene?), northern Uinta basin, northeastern Utah: Utah Geology, v.2, p.1-15.

Ritzma, H. R., 1965, Fossil soil at the base of Paleocene rocks, southern Rock springs uplift, Wyoming: Wyoming Geological Association, 19 th Annual Field Conference Guidebook, p. 137-139.

Roehler, H. W., 1961, The late Cretaceous - Tertiary boundary in the Rock springs uplift, Sweetwater County, Wyoming: Wyoming Geological Association, 16th Annual Field Conference Guidebook, p. 96-100.

Roehler, H. W., 1965, Early Tertiary depositional environments in the Rock Springs uplift area: Wyoming Geological Association, 19 th Annual Field Conference Guidebook, p. 140-150.

Roehler, H. W., 1972, Geologic map of the Four J Rim Quadrangle, Sweetwater County, Wyoming and Moffat County, Colorado: U.S. Geolgical Survey, GQ 1002, scale $1: 24,000$.

Roehler, H. W., 1973a, Geologic map of the Ericson-Kent Ranch Quadrangle, Sweetwater County, Wyoming: U.S. Geological Survey, GQ 1056, scale 1:24,000. 
Roehler, H. W., 1973b, Geologic map of the Potter Mountain Quadrangle, Sweetwater Couty, wyoming: U.S. Geological Survey, GQ 1082, scale 1:24,000.

Roehler, H. W., 1973c, Geologic map of the Titsworth Gap Quadrangle, Sweetwater County, Wyoming: U.S. Geological Survey, GQ 1083, scale 1:24,000.

Roehler, H. W., 1974a, Geologic map of the Burley Draw Quadrangle, Sweetwater County, Wyoming: U.S. Geological Survey, GQ 1200, scale 1:24,000.

Roehler, H. W., 1974b, Geologic map of the Chicken Creek West Quadrangle, Sweetwater County, Wyoming: U. S. Geological survey, GQ 1139, scale 1:24,000.

Roehler, H. W., 1974c, Geologic map of the Pine Butte Quadrangle, Sweetwater County, Wyoming: U. S. Geologic Survey, GQ 1199, scale 1:24,000.

Roehler, H. W., 1974d, Geologic map of the Scrivner Butte Quadrangle, Sweetwater County, Wyoming, and Moffat County, Colorado: U. S. Geological Survey, GQ 1166, scale $1: 24,000$.

Roehler, H. W., 1977, Geologic map of the Sand Butte Rim NW Quadrangle, Sweetwater County, Wyoming: U. S.

Geological Survey, GQ 1362, scale 1:24,000.

Roehler, H. W., 1979a, Geological and energy resources of the Sand Butte Rim NW quadrangle, Sweetwater County, Wyoming: U.S. Geological Survey Professional Paper 1065-A, p. A1-A54.

Roehler, H. W., 1979b, Geology and mineral resources of the Mud Springs Ranch Quadrangle, Sweetwater County, Wyoming: U.S. Geological Survey Professional Paper 1065-C, p. C1-C16.

Roehler, H. W., 1981, Correlation of Eocene rocks in measured sections in the southeast and west parts of the Rock springs coal field, Wyoming: U.S. Geological Survey Chart oc-111, 2 sheets. 
Shuster, M. W., and steidtmann, J. R., 1988, Tectonic and sedimentary evolution of the northern Green River basin, western Wyoming, in schmidt, C. J., and Perry, W. J., eds., Interaction of the Rocky Mountain foreland and Cordilleran thrust belt: Geological society of America Memoir 171, p. 515-529.

Singh, I. D., 1972, On the bedding in the natural-levee and the point-bar deposits of the Gomti River, Uttar Pradesh, India: Sedimentary Geology, v. 7, p. 309-317.

Sklenar, S. E., and Andersen, D. W., 1985, Origin and early evolution of an Eocene lake system within the Washakie basin of southeastern Wyoming, in Flores, R. M., and Kaplan, S. S., eds., Cenozoic paleogeography of the west-central United States: Denver, Rocky Mountain Section, Society of Economic Paleontologists and Mineralogists, p. 231-245.

Smith, D. G., 1983, Anastomosed fluvial deposits: modern examples from western Canada, in Collinson, J. D., and Lewin, J., eds., Modern and ancient fluvial systems: International Association of Sedimentologists special Publication 6, p. 155-168.

Steidtmann, I, R., Middleton, I, T, Bottjex, R. I, , Jackson, R. E., McGee, L. C., Southwell, E. H., Lieblang, S., 1986, Geometry, distribution, and provenance of tectonic conglomerates along the southern margin of the Wind River Range, Wyoming, in Peterson, J.A., ed., Paleotectonics and sedimentation in the Rocky Mountain region, United States: American Association of Petroleum Geologists Memoir 41, p. 321332 .

Sullivan, R., 1980, A stratigraphic evaluation of the Eocene rocks of southwestern Wyoming: Wyoming Geological Survey Report of Investigations $20,50 \mathrm{p}$.

Tollestrup, A. K., and Steidtmann, J. R., 1990, Mixed sediment provenance in the Laramide foreland of Wyoming: examples in the southeastern Green River basin (abs.): Geological Society of America, Abstracts with Programs, v. 22, p. 48 . 
Tyler, N., and Ethridge, F. G., 1983, Fluvial archtecture of Jurassic uranium-bearing sandstones, 
Stratigraphic sections were measured in field areas $I$, II and III. Field areas are assigned a Roman numeral. Individual measured sections within a field area are designated by a letter of the alphabet and units within a section are numbered with Arabic numerals.

\section{Field Area I}

Field area I is located in the Ericksun - Rent Ranch 7.5-minute quadrangle, Sweetwater County, Wyoming. Stratigraphic sections were measured in sec. 4 and sec. 5 , T. 14 N., R. $101 \mathrm{~W}$. The locations of stratigraphic sections are given in Figure 22. The stratigraphic sections were measured within the lower Wasatch Formation.

\section{Section A}

Section $A$ was measured from the Fort - Union Wasatch boundary located in $\mathrm{NW} 1 / 4, \mathrm{NE} \mathrm{1/4,SW} \mathrm{1/4,} \mathrm{sec.} 5$, T. $14 \mathrm{~N}$, , R. $101 \mathrm{~W}$., to NE $1 / 4, \mathrm{NE} 1 / 4, \mathrm{SW} 1 / 4$, sec. $5, \mathrm{~T}$. 14 N., R. $101 \mathrm{~W}$.

Top of section: eroded

\begin{tabular}{cc}
$\begin{array}{c}\text { Unit } \\
\text { Thickness }\end{array}$ & $\begin{array}{c}\text { Stratigraphic } \\
\text { Location } \\
\text { (Meters) }\end{array}$ \\
\hline
\end{tabular}

5. Sandstone, yellowish-gray, massive, thin- to thick-bedded, cross-stratified, convoluted, "unstratified," ripplestratified at top, mediumgrained; erosional base........

4. Silty claystone, light-gray

to greenish-gray, locally

carbonaceous; interbedded with

sandstone, light-gray to yellowish-gray, flaggy, thinbedded, ripple-stratified. locally cross-stratified, finegrained................. 


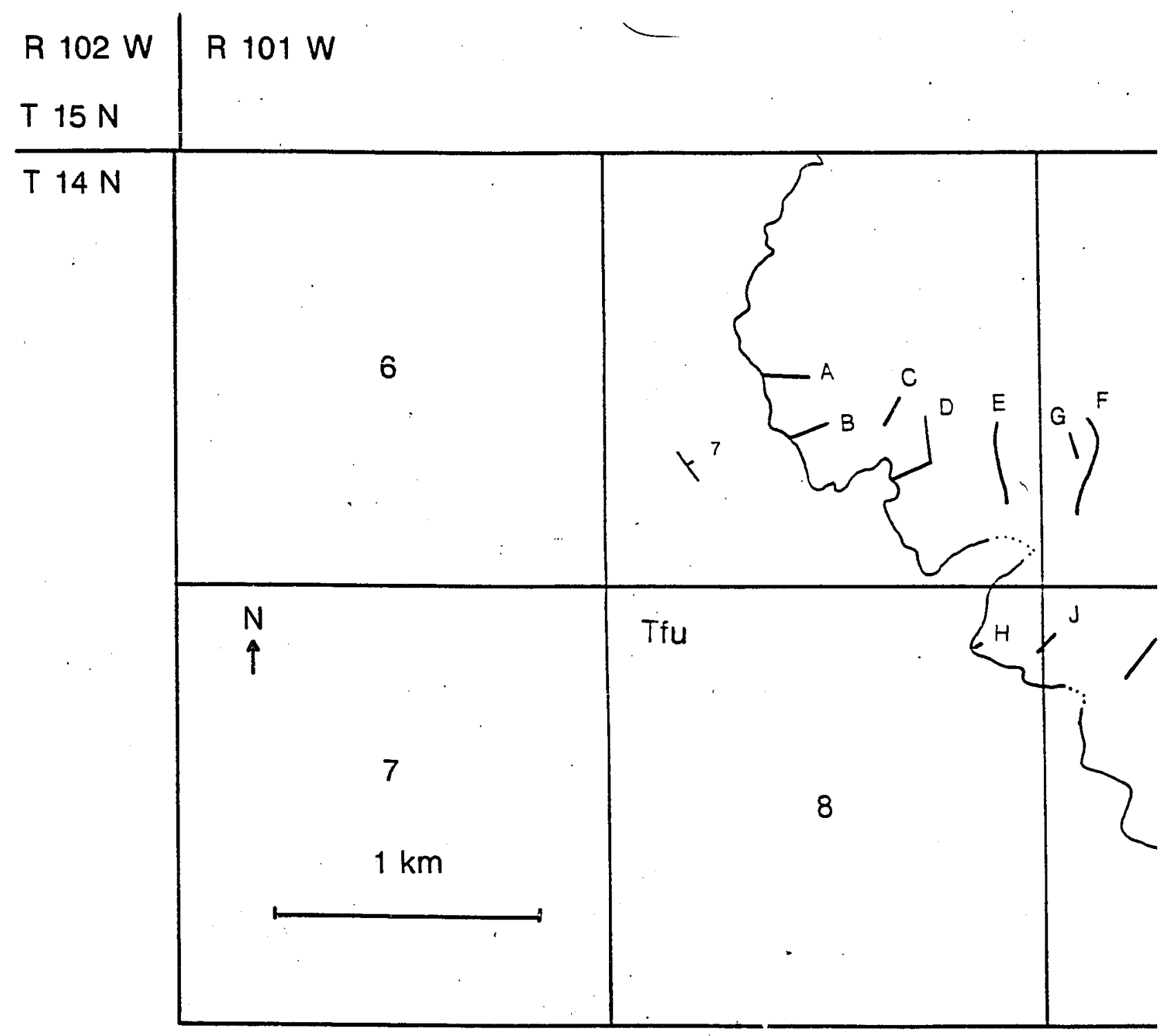

Figure 22. Location map for measured sections in field area $I$. The geologic base map shows contact between the Fort Union Formation (Tfu) and Wasatch Formation (Twm) from Roehler (1973a). 
T $15 \mathrm{~N}$

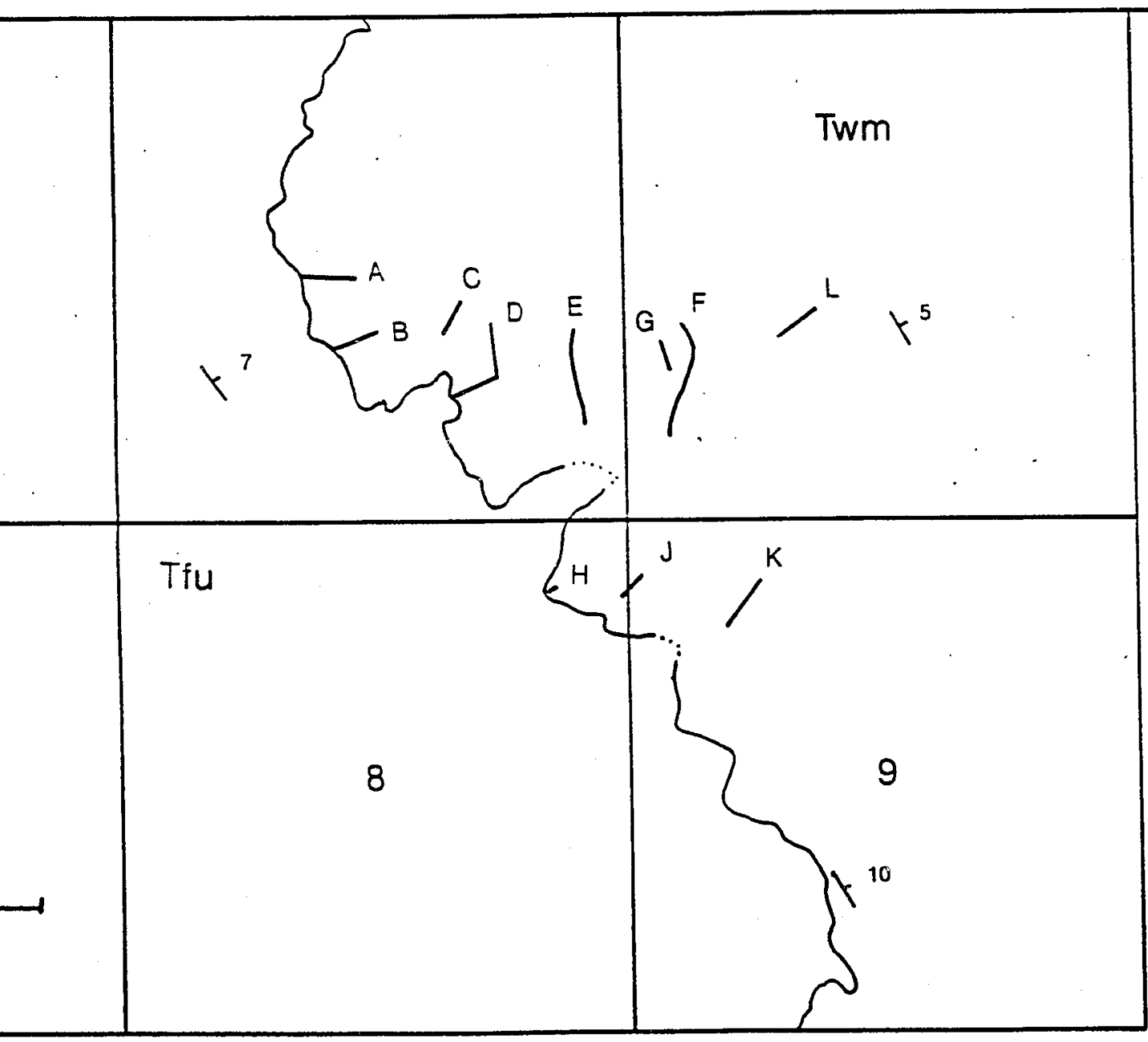

measured sections in field hows contact between the asatch Formation ( $\mathrm{Twm}$ ) from 
3. Sandstone, yellowish-gray, flaggy, very thin-bedded, ripple-stratified, burrowed, fine-grained; gradational base..

$0.7 \quad 24.3$

2. Silty claystone, greenishgray, locally carbonaceous; interbedded with sandstone, yellowish-gray, thin-bedded, locally cross-stratified, ripple-stratified, fine-

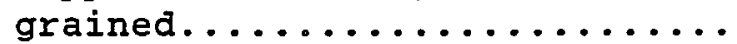

$9.8 \quad 14.5$

1. Sandstone, light-gray, massive, thin- to thick-bedded, cross-stratified, ripplestratified at top, mediumgrained; mud pebble beds overlie erosional base, upper contact

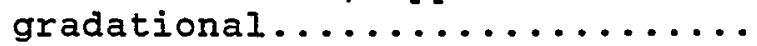
14.5 0.0

Partial thickness of the Wasatch

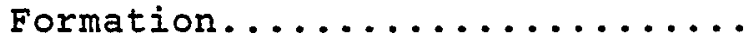

Base of section: section overlies light-gray silty claystone of the Fort Union Formation.

Section B

Section $B$ was measured from the Fort Union - Wasatch boundary located in SW 1/4, NE 1/4, SW 1/4, sec. 5, T. 14 N., R. $101 \mathrm{~W}$. to SE $1 / 4$, NE 1/4, SW 1/4, sec. 5, T. $14 \mathrm{~N}$, R. 101 W.

Top of section: eroded

Unit Thickness (Meters)
Stratigraphic

Location (Meters) 
7. Sandstone, medium-gray, massive, thin-bedded, crossstratified, "unstratified," medium grained; mud pebbles

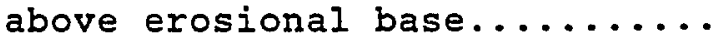

$7.6 \quad 46.4$

6. Claystone, medium-gray....

3.2

43.2

5. Sandstone, very light-gray, thin-bedded, "unstratified,"

fine-grained..............

2.3

40.9

4. Silty claystone, light- to medium-gray; interbedded with sandstone, light-gray, very thin- to thin-bedded, ripplestratified, locally crossstratified, fine-grained......

3. Sandstone, light-gray, very thin- to thin-bedded, ripplestratified, burrowed, very fineto fine-grained.............

2. Silty claystone, greenishgray..................

1. Sandstone, grayish-yellow, thin- to thick-bedded, crossstratified, convoluted, ripplestratified at top, mediumgrained; mud pebble layer overlies erosional base........ $10.6 \quad 0.0$

Partial thickness of the Wasatch

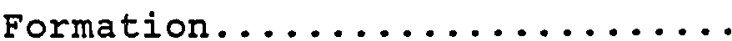

Base of section: Wasatch Formation overlies very light-gray claystone of the Fort Union Formation

Section C

Section $C$ was measured within the Wasatch Formation at NE 1/4, NW 1/4, SE 1/4, sec. 5, T. 14 N., R. 101 W.

Top of section: eroded 


$\begin{array}{cc}\text { Unit } & \text { Stratigraphic } \\ \text { Thickness } & \text { Location } \\ \text { (Meters) } & \text { (Meters) }\end{array}$

5. Silty claystone, light-gray; interbedded with sandstone, light-gray, very thin- to thinbedded, ripple-stratified, burrowed, fine-grained.........

37.8

4. Sandstone, grayish-yellow, flaggy, thin-bedded, ripplestratified, cross-stratified, "unstratified," medium-grained..

2.3

35.5

3. Silty claystone, pale-olive, locally pale-red; interbedded with sandstone, light-gray, very thin-bedded, ripple-stratified, "unstratified," burrowed, finegrained..................

2. Sandstone, yellowish-gray, very thin-bedded, ripplestratified, "unstratified," burrowed, medium-grained.......

2.5 14.3

1. Claystone, greenish-gray; interbedded with sandstone, light-gray, very thin-bedded, ripple-stratified, "unstratified," burrowed, finegrained.................. 14.3

0.0

Partial thickness of the Wasatch

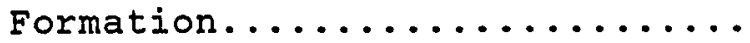

41.0

Base of section: section overlies light-gray silty claystone of the Wasatch Formation. 
Section D

Section $D$ was measured from the Fort Union - Wasatch boundary located at $\mathrm{SE} 1 / 4, \mathrm{NW} 1 / 4, \mathrm{SE} 1 / 4$, sec. 5, T. 14 N., R. $101 \mathrm{~W}$. to $\mathrm{NE} 1 / 4$, NW $1 / 4, \mathrm{SE} 1 / 4$, sec. 5, T. $14 \mathrm{~N}$, R. 101 W.

Top of section: eroded

\begin{tabular}{cc}
$\begin{array}{c}\text { Unit } \\
\text { Thickness }\end{array}$ & $\begin{array}{c}\text { Stratigraphic } \\
\text { (Moters) }\end{array}$ \\
\hline
\end{tabular}

7. Sandstone, light-gray, massive, thin- to thick-bedded, cross-stratified, mediumgrained; mud pebble beds overlie erosional base..............

$\begin{array}{ll}5.7 & 68.8\end{array}$

6. Silty claystone, pale-olive, locally pale-red; interbedded with sandstone, light-gray, very thin- to thin-bedded, ripplestratified, locally crossstratified, fine-grained.......

5. Sandstone, light-gray, very thin-bedded, ripple-stratified, burrowed, fine-grained.........

$0.7 \quad 60.4$

4. Silty claystone, light-gray, locally pale red; interbedded with sandstone, light-gray, "unstratified," burrowed, medium-grained.............

3. Sandstone, light-gray, very thin-bedded, "unstratified," ripple-stratified, burrowed, medium-grained.............. 
2. Silty claystone, light-gray

to pale-olive; interbedded with sandstone, light-gray, very thin- to thin-bedded, ripplestratified, locally crossstratified, burrowed, fine- to medium-grained.............

43.8

10.7

1. Sandstone, light-gray, massive, thin-to thick-bedded, cross-stratified, convoluted, ripple-stratified at top, medium-grained with coarsegrained lenses near the base; mud pebbles above erosional

base, upper contact gradational.

$10.7 \quad 0.0$

Partial thickness of the Wasatch

Formation................

74.5

Base of section: Wasatch Formation overlies light gray claystone of Fort Union Formation.

Section $\mathbf{E}$

Section $E$ was measured within the Wasatch Formation from $\mathrm{NE} 1 / 4, \mathrm{SE} 1 / 4, \mathrm{SE} 1 / 4$, sec. 5, T. $14 \mathrm{~N} ., \mathrm{R} .101 \mathrm{~W}$. to $\mathrm{NE} 1 / 4, \mathrm{NE} 1 / 4, \mathrm{SE} 1 / 4$, sec. 5, T. 14 N., R. $101 \mathrm{~W}$.

Top of section: eroded

\begin{tabular}{cc}
$\begin{array}{c}\text { Unit } \\
\text { Thickness }\end{array}$ & $\begin{array}{c}\text { Stratigraphic } \\
\text { (Moters) }\end{array}$ \\
\hline
\end{tabular}

7. Sandstone, very light-gray, thin-bedded, ripple-stratified, burrowed, fine-grained.........

$0.9 \quad 60.0$ 
6. Silty claystone, light-gray to light-olive-gray; interbedded with sandstone, light-gray, thin-bedded, ripple-stratified, "unstratified," burrowed, very fine- to fine-grained.........

$7.4 \quad 52.6$

5. Sandstone, light-gray, massive, thin- to thick-bedded, cross-stratified,

"unstratified," medium-grained; mud pebble layer overlies erosional base..............

$9.9 \quad 42.7$

4. Silty claystone, mediumgray; interbedded with sandstone, light-gray, very thin-bedded, ripple-stratified, burrowed, fine-grained..........

3. Sandstone, yellowish-gray, very thin-bedded, ripplestratified, burrowed, finegrained.................

$14.3 \quad 28.4$

2. Silty claystone, light-gray, locally pale-red; interbedded with sandstone, light-gray, very thin-bedded, ripple-stratified, "unstratified," locally crossstratified, burrowed, fine- to medium-grained.............

1. Sandstone, light-gray, massive, thick-bedded, crossstratified, "unstratified," medium-grained; mud pebble layer overlies erosional base........

Partial thickness of the Wasatch Formation................

Base of section: section overlies light-gray claystone of the Wasatch Formation. 
Section $F$

Section $F$ was measured within the Wasatch Formation

from NW 1/4, SW 1/4, SW 1/4, sec. 4, T. 14 N., R. 101 W. to NW 1/4, NW 1/4, SW 1/4, sec. 4, T. 14 N., K. 101 W.

Top of section: eroded

Unit

Thickness

(Meters)
Stratigraphic

Location

(Meters)

7. Clayey siltstone and silty claystone, dark reddish-brown; interbedded with sandstone, light-gray, thin-bedded,

"unstratified," fine-grained....

4.7

45.0

6. Sandstone, light-gray, massive, thick-bedded, crossstratified, ripple-stratified at top, medium-grained with coarsegrained lenses near the base; mud pebble layers overlie erosional base..............

37.8

5. Clayey siltstone and silty claystone, light-gray; interbedded with sandstone, light-gray, "unstratified," burrowed, fine-grained.........

4.2

33.6

4. Sandstone, light-gray, very thin-bedded, ripple-stratified, burrowed, fine-grained........

0.5

33.1

3. Clayey siltstone, lightgray, sharp base............ 
2. Sandstone, dusky-yellow, very thin-bedded, ripplestratified, burrowed, mediumgrained (note: panel depicts projected thickness)..........

$0.9 \quad 30.1$

1. Silty claystone, light-gray

to greenish-gray; interbedded with sandstone, light-gray, thin-bedded, ripple-stratified, burrowed, fine- to medium-

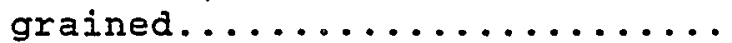

30.1

0.0

Partial thickness of the Wasatch

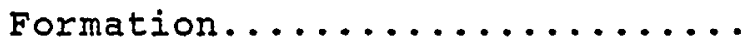

49.7

Base of section: section overlies light-gray siltstone of the Wasatch Formation.

\section{Section G}

Section $G$ was measured within the Wasatch Formation from the $\mathrm{SW} 1 / 4, \mathrm{NW} 1 / 4, \mathrm{SW} 1 / 4$, sec. 4, T. $14 \mathrm{~N} ., \mathrm{R} .101 \mathrm{~W}$. to $\mathrm{NW} 1 / 4, \mathrm{NW} 1 / 4, \mathrm{SW} 1 / 4, \mathrm{~T}, 14 \mathrm{~N}$, , R. $101 \mathrm{~W}$.

Top of section: section overlain by light-gray silty claystone of the Wasatch Formation.

\begin{tabular}{cc} 
Unit & Stratigraphic \\
Thickness & Location \\
(Meters) & (Meters) \\
\hline
\end{tabular}

6. Sandstone, light-gray, thinbedded, ripple-stratified, "unstratified," burrowed, medium-grained............. 27.8

5. Silty claystone and clayey siltstone, medium-gray.........

4. Sandstone, light-gray, thinbedded, ripple-stratified, cross-stratified in upper portion, burrowed, mediumgrained.................. 
3. Claystone, pale-red........

1.9

17.1

2. Sandstone, light-gray, massive, thin-to thick-bedded, cross-stratified,

"unstratified," ripplestratified at top, medium-

grained; erosional base........

9.7

7.4

1. Silty claystone, light-gray;

interbedded with sandstone,

light-gray to grayish-yellow, thin-bedded, ripple-stratified, locally cross-stratified, fineto medium-grained; gradational

to sharp base...............

$\begin{array}{ll}7.4 & 0.0\end{array}$

Partial thickness of the Wasatch

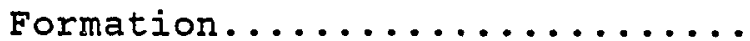

30.2

Base of section: section overlies light-gray silty claystone of the Wasatch Formation.

Section $\mathrm{H}$

Section $H$ was measured within the Wasatch Formation from SE 1/4, NE 1/4, NE 1/4, sec. 8, T. $14 \mathrm{~N}$, R. $101 \mathrm{~W}$. to $\mathrm{NE} 1 / 4, \mathrm{NE} 1 / 4, \mathrm{NE} 1 / 4$, sec. 8, T. $14 \mathrm{~N} ., \mathrm{R} .101 \mathrm{~W}$.

Top of section: eroded

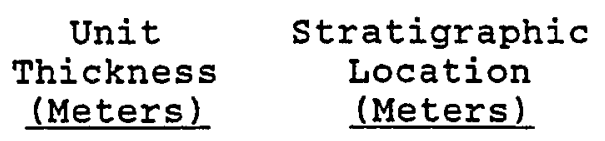

6. Sandstone, very light-gray, massive, thin- to thick-bedded, cross-stratified, convoluted, "unstratified," medium-grained; erosional base.............. 13.9 12.5

5. Claystone, light gray......

3.8 8.7 
4. Sandstone, medium-lightgray, massive, thick-bedded, cross-stratified, convoluted, ripple-stratified at top, medium-grained; mud pebbles overlie erosional base.........

3. Coal, black, carbonaceous;

interbedded with sandstone, light-gray, very thin-bedded, ripple-stratified, fine-

0.3

1.9

grained................

2. Sandstone, medium-grāy,

thin-bedded, cross-stratified, convoluted, medium-grained;

erosional base.............

0.6

1.3

1. Claystone, very light-gray;

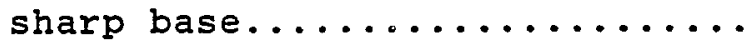

$1.3 \quad 0.0$

Partial thickness of the Wasatch

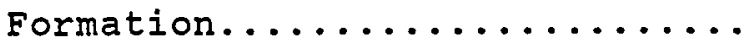

26.4

Base of section: section overlies pale-red claystone, a weathered zone (Roehler, 1973a), of the Fort Union

Formation.

\section{Section $J$}

Section $J$ was measured within the Wasatch Formation from SE 1/4, NE 1/4, NE 1/4, sec. 8, T. 14 N., R. $101 \mathrm{~W}$. to SW 1/4, NW 1/4, NW 1/4, sec. 9, T. 14 N., R. 101 W.

Top of section: eroded

\begin{tabular}{cc}
$\begin{array}{c}\text { Unit } \\
\text { Thickness }\end{array}$ & $\begin{array}{c}\text { Stratigraphic } \\
\text { Location } \\
\text { (Meters) }\end{array}$ \\
\hline
\end{tabular}

4. Claystone, light-gray; interbedded with sandstone, dusky-yellow, flaggy, thinbedded, ripple-stratified, locally cross-stratified, medium-grained.............. 
3. Sandstone, dusky-yellow, flaggy, thin-bedded, ripplestratified, medium-grained......

$1.8 \quad 40.7$

2. Silty claystone, light-gray;

interbedded with sandstone,

light-gray, flaggy, very thin-

to thin-bedded, ripple-

stratified, cross-stratified,

burrowed, fine- to medium-

grained..................

27.5

13.2

1. Sandstone, light-gray, massive, thick-bedded, crossstratified, "unstratified,"

convoluted, medium-grained......

13.2

0.0

Partial thickness of the Wasatch

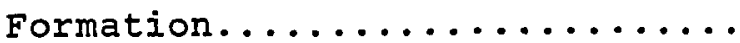

49.8

Base of section: covered

Section $\mathrm{K}$

Section $K$ was measured within the Wasatch Formation from SE $1 / 4$, NW 1/4, NW 1/4, sec. 9, T. $14 \mathrm{~N} ., \mathrm{R} .101 \mathrm{~W}$. to NW $1 / 4$, NE 1/4, NW 1/4, sec. 9, T. 14 N., R. 101 W.

Top of section: eroded

$\begin{array}{cc}\text { Unit } & \text { Stratigraphic } \\ \text { Thickness } & \text { Location } \\ \text { (Meters) } & \text { (Meters) }\end{array}$

8. Clayey siltstone and silty

claystone, pale-olive:

interbedded with sandstone, yellowish-gray to dusky-yellow,

flaggy, very thin- to thin-

bedded, ripple-stratified,

burrowed, very fine- to fine-

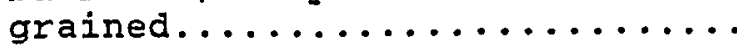

7.5

46.1 
7. Sandstone, dusky-yellow, very thin-bedded, ripplestratified, burrowed, finegrained.................
1.1
45.0

6. Silty claystone, light-gray, locally carbonaceous; interbedded with sandstone, light-gray, flaggy, very thinto thin-bedded, ripplestratified, locally crossstratified, burrowed, fine- to medium-grained............. 20.5 24.5

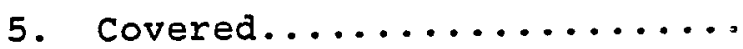

4. Silty claystone, pale-red; interbedded with sandstone, light-gray, flaggy, thin-bedded, ripple-stratified, locally cross-stratified, medium-grained

3. Sandstone, light-gray, Elaggy, thin-bedded, ripplestratified, burrowed, fine-

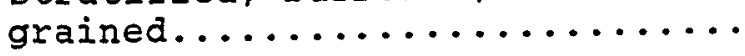

2. Sandstone, light-gray, slabby, thin-bedded, ripplestratified, medium-grained; interbedded with silty claystone and clayey siltstone, pale-olive

1. Sandstone, light-gray, massive, thick-bedded, crossstratified, ripple-stratified at top, medium-grained, fine- to very fine-grained at top; mud pebble layer overlies erosional

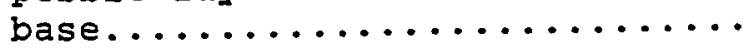

Partial thickness of the Wasatch Formation...............

Base of section: section overlies light-gray claystone of the Wasatch Formation. 
Section L

Section $I$ was measured within the Wasatch Formation from SW 1/4, NE 1/4, SW 1/4, sec. 4, T. $14 \mathrm{~N} ., \mathrm{R} .101 \mathrm{~W}$. to NE 1/4, NE 1/4, SW 1/4, sec. 4, T. 14 N., R. $101 \mathrm{~W}$.

Top of section: eroded

$\begin{array}{cc}\text { Unit } & \text { Stratigraphic } \\ \text { Thickness } & \text { Location } \\ \text { (Meters) } & \text { (Meters) }\end{array}$

6. Silty claystone, greenishgray, locally pale-red;

interbedded with sandstone, light-gray to yellowish-gray, very thin- to thin-bedded, ripple-stratified, "unstratified," burrowed, medium-grained............. 20.2 50.3

5. Sandstone, pale-olive, very thin-bedded, ripple-stratified, burrowed, fine-grained.........

0.8

49.5

4. Claystone, light-gray; interbedded with sandstone, light-gray, thin-bedded, ripplestratified, "unstratified," burrowed, fine-grained........

3. Sandstone, dusky-yellow, "unstratified," medium-grained, gradational base............

2. Silty claystone and clayey siltstone, light-gray to grayish-olive; interbedded with sandstone, light-gray, very thin-to thin-bedded, ripplestratified, "unstratified," burrowed, fine- to mediumgrained.................

1. Sandstone, light-olive-gray, "unstratified," burrowed, medium-grained gradational base. 
Partial thickness of the Wasatch

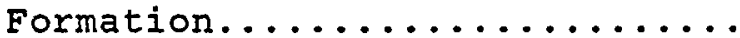

70.5

Base of section: section overlies light-gray silty claystone of the Wasatch Formation.

\section{Field Area II}

Field area II is located within the Potter Mountain, Four-J Rim and Titsworth Gap 7.5-minute quadrangles, Sweetwater County, Wyoming. Stratigraphic sections A through EE were measured in sec. 1,2 and $3, T .13 \mathrm{~N} .$, R. 103 W.; sec. $5,6,7$, and 8 T. 13 N., R. 102 W. and sec. 35 and 36, T. $14 \mathrm{~N} ., \mathrm{R} .103 \mathrm{~W}$. The locations of stratigraphic sections are given in Figure 23.

Section A

Section $A$ was measured within the Fort Union and Wasatch Formations from $N W 1 / 4, N E 1 / 4, N W 1 / 4$, sec. 3 , T. $13 \mathrm{~N}$, , R. $103 \mathrm{~W}$. to NE 1/4, NW 1/4, NE 1/4, sec. 3, T. $13 \mathrm{~N} ., \mathrm{R} .103 \mathrm{~W}$.

Top of section: eroded

$\begin{array}{cc}\text { Unit } & \text { Stratigraphic } \\ \text { Thickness } & \text { Location } \\ \text { (Meters) } & \text { (Meters) }\end{array}$

6. Sandstone, light-gray,

massive, thin-to thick-bedded, cross-stratified,

"unstratified," medium- to coarse-grained; mud pebble layer

overlies erosional base........

$13.0 \quad 0.0$ 


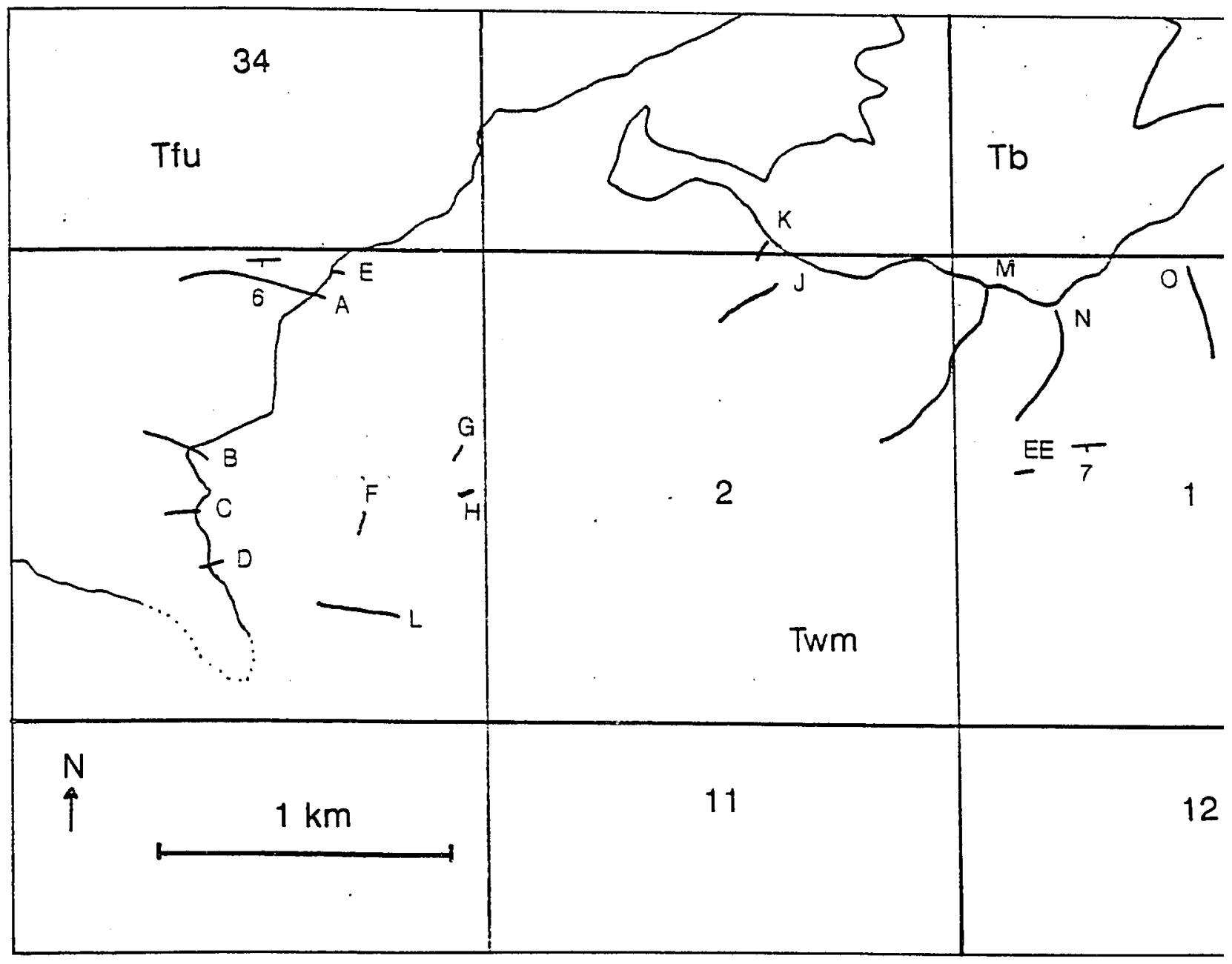

Figure 23. Location map for measured sections in field area II. The geologic base map depicts the Fort Union Eormation (Tfu), Wasacch Formation ( $T w m$ ), Luman Tongue of the Green River Eormation (Tglu), and Bishop Conglomerate (Tb) from Roehler (1972, 1973b). 


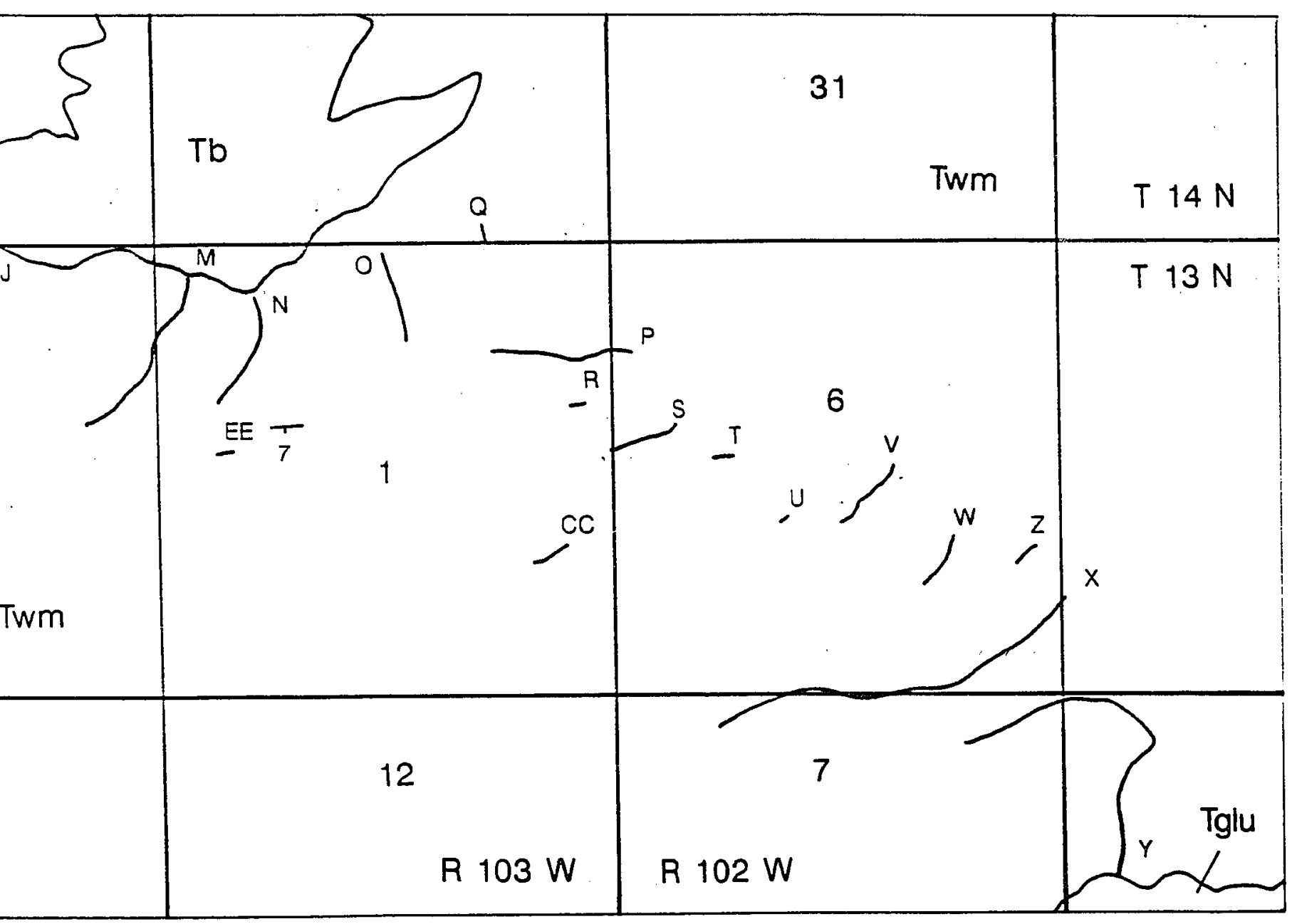

rions in field

rt Union

n Tongue of onglomerace 
Partial thickness of the Wasatch



13.0

5. Silty claystone, greenishgray to yellowish-gray;

interbedded with sandstone, light-gray, thin-bedded, ripplestratified, medium-grained; interbedded with limestone, medium-gray, microcrystalline...

4. Sandstone, light-gray, very thin-bedded, ripple-stratified, fine-grained; interbedded with Iimestone, light-gray, microcrystalline............

3. Silty claystone, lightolive-gray; interbedded with sandstone, light-gray, very thin- to thin-bedded, ripplestratified, burrowed, finegrained; interbedded with limestone, light-gray, microcrystalline.............

2. Sandstone, light-gray, massive, thick-bedded, crossstratified, rippled at top, medium-grained; erosional base..

1. Sandstone, light-gray, massive, thin-to thick-bedded, cross-stratified, "unstratified," , mediumgrained; SW-dipping second-order contacts.................

Partial thickness of the Fort Union Formation..............

Base of section: covered 
Section B

Section $B$ was measured within the Fort Union and Wasatch Formations from $S W 1 / 4, \operatorname{SE~} 1 / 4, N W 1 / 4, \sec .3$, T. 13 N., R. 103 W. to $S E 1 / 4, S E 1 / 4, N W 1 / 4, \sec 3$, T. 13 N., R. $103 \mathrm{~W}$.

Top of section: eroded

Unit Thickness (Meters)

\section{Stratigraphic Location (Meters)}

8. Sandstone, massive, Iightgray, thin- to thick-bedded, cross-stratified,

"unstratified," ripple-

stratified at top, mediumgrained; mud pebbles overlie erosional base..............

4.7

0.0

Partial thickness of the Wasatch Formation.................

4.7

7. Silty claystone, lightolive-gray, locally carbonaceous; interbedded with sandstone, light-gray, thinbedded, ripple-stratified, burrowed, fine- to mediumgrained; interbedded with limestone, yellowish-gray, lenticular, microcrystalline....

8.9 54.3 
6. Sandstone, light-gray, flaggy, thin-bedded, ripplestratified, "unstratified," burrowed, fine- to mediumgrained; interbedded with silty claystone, light-gray, locally carbonaceous................
7.1
47.2

5. Sandstone, light-gray, massive, thin- to thick-bedded, cross-stratified, convoluted, "unstratified," ripplestratified at top, mediumgrained; mud pebbles overlie erosional base..............

4. Silty claystone, lightolive-gray; interbedded with sandstone, light-gray, flaggy, thin-bedded, ripple-stratified, burrowed, fine- to mediumgrained; interbedded with limestone, olive-gray, microcrystalline...........

3. Sandstone, light-gray, massive, thin- to thick-bedded, cross-stratified, convoluted, ripple-stratified at top, medium-grained; mud pebbles overlie erosional base.........

2. Silty claystone, lightolive-gray, locally carbonaceous

1. Sandstone, light-gray, massive, thin- to thick-bedded, cross-stratified, convoluted, ripple-stratified at top, medium-grained; mud pebbles overlie erosional base.........

Partial thickness of the Fort

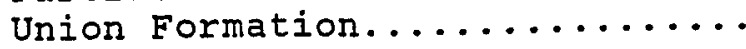

Base of section: section overlies brown, carbonaceous shale of the Wasatch Formation. 
Section $\mathrm{C}$

Section $C$ was measured within the Fort Union and Wasatch Formations at $\mathrm{SW} \mathrm{1/4,NE} \mathrm{1/4,} \mathrm{SW} \mathrm{1/4,} \mathrm{sec.} \mathrm{3,}$ T. 13 N., R. $103 \mathrm{~W}$.

Top of section: eroded

$\begin{array}{cc}\text { Unit } & \text { Stratigraphic } \\ \text { Thickness } & \text { Location } \\ \text { (Meters) } & \text { (Meters) }\end{array}$

5. Sandstone, light-gray, massive, thin- to thick-bedded, cross-stratified,

"unstratified," medium-grained, locally very coarse- to coarsegrained; south-dipping secondorder contacts, mud pebble layer overlies erosional base........

$5.5 \quad 4.5$

4. Sandstone, light-gray, massive, thin- to thick-bedded, cross-stratified, convoluted, "unstratified," medium-grained; mud pebble layer overlies erosional base.............. 4.5 0.0

Partial thickness of the wasatch

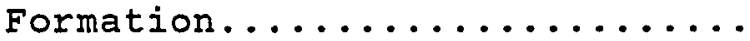

10.0

3. Silty claystone, light-gray; interbedded with sandstone, light-gray, flaggy, thin-bedded, ripple-stratified,

"unstratified," fine-grained....

9.0 20.3 
2. Sandstone, light-gray, thinbedded, ripple-stratified, locally cross-stratified, fine-

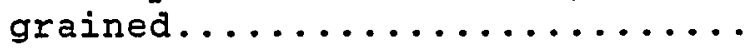

1. Silty claystone, light-olivegray, locally carbonaceous; interbedded with sandstone, light-gray, flaggy, very thinto thin-bedded, ripplestratified, locally crossstratified, burrowed, fine-

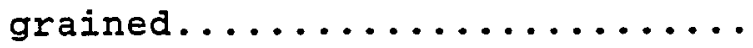

Partial thickness of the Fort Union Formation.............

Base of section: section overlies light-gray silty claystone of the Fort Union Formation.

Section D

Section $D$ was measured within the Wasatch Formation at SE 1/4, NE 1/4, SW 1/4, sec. 3, T. 13 N., R. 103 W.

Top of section: eroded

Unit Thickness (Meters) \begin{tabular}{c} 
Stratigraphic \\
Location \\
(Meters) \\
\hline
\end{tabular}

6. Sandstone, light-gray, massive, thin- to thick-bedded, cross-stratified, "unstratified," medium-grained; mud pebble layer overlies erosional base.............. 12.2 26.2

5. Silty claystone, light olive-gray................ 2.5 23.7

4. Sandstone, light-gray, massive, thin- to thick-bedded, cross-stratified, convoluted, "unstratified," medium-grained; mud pebbles overlie erosional

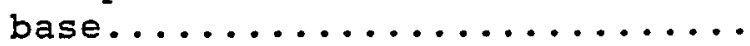


3. Sandstone, Iight-gray, massive, thin- to thick-bedded, cross-stratified, convoluted, "unstratified," medium-grained, locally coarse-grained: mud pebble layer overlies erosional base....................

2. Sandstone, light-gray, massive, thin-to thick-bedded, cross-stratified, "unstratified," ripplestratified at top, mediumgrained, locally coarse-grained above base and very fine- to fine-grained at top; mud pebble layer overlies erosional base...

1. Sandstone, light-gray, massive, thin- to thick-bedded, cross-stratified, ripplestratified at top, mediumgrained, locally coarse- and very coarse-grained; mud pebbles overlie erosional base......... $5.0 \quad 0.0$

Partial thickness of the Wasatch Formation................

Base of section: section overlies light-gray silty claystone of the Fort Union Formation.

Section $E$

Section $E$ was measured within the Wasatch Formation at $\mathrm{NE} 1 / 4, \mathrm{NW} 1 / 4, \mathrm{NE} 1 / 4$, sec. 3, T. $13 \mathrm{~N} ., \mathrm{R} .103 \mathrm{~W}$.

Top of section: eroded

Unit Thickness (Meters)
Stratigraphic
Location
(Meters) 
2. Sandstone, light-gray,

massive, thin- to thick-bedded, cross-stratified, medium-

grained; mud pebble layer

overlies erosional base...........

$9.0 \quad 5.8$

1. Silty claystone, light-gray. $\quad 5.8 \quad 0.0$

Partial thickness of the Wasatch

Formation................ 14.8

Base of section: overlies light-gray, cross-stratified sandstone of the Wasatch Formation.

\section{Section $\mathbf{F}$}

Section $F$ was measured within the Wasatch Formation at NE 1/4, NW 1/4, SE 1/4, sec. 3, T. 13 N., R. $103 \mathrm{~W}$.

Top of section: eroded

$\begin{array}{cc}\text { Unit } & \text { Stratigraphic } \\ \text { Thickness } & \text { Location } \\ \text { (Meters) } & \text { (Meters) }\end{array}$

3. Sandstone, light-gray,

massive, thin- to thick-bedded, cross-stratified, convoluted,

"unstratified," medium-grained;

mud pebble layer overlies

erosional base..............

$9.2 \quad 20.2$

2. Silty claystone, light-

olive-gray................

$6.6 \quad 13.6$

1. Sandstone, light-gray,

massive, thin- to thick-bedded, cross-stratified,

"unstratified," ripple-

stratified at top, medium-

grained, fine- to very fine-

grained at top; mud pebble layer

overlies erosional base........
13.6
0.0 
Partial thickness of the Wasatch

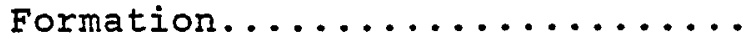

29.4

Base of section: section overlies light-gray silty claystone of the Wasatch Formation.

Section $G$

Section $G$ was measured within the Wasatch Formation at $\mathrm{SE} 1 / 4, \mathrm{SE} 1 / 4, \mathrm{NE} 1 / 4$, sec. 3, T. $13 \mathrm{~N} ., \mathrm{R} .103 \mathrm{~W}$.

Top of section: eroded

Unit

Thickness

(Meters)
Stratigraphic Location

(Meters)

3. Sandstone, light-gray, massive, thin- to thick-bedded, cross-stratified, convoluted, medium-grained..............

2. Claystone, very light-gray; interbedded with claystone, white, calcareous............

1. Sandstone, light-gray, massive, thin- to thick-bedded, cross-stratified, mediumgrained, locally coarse-grained; mud pebble layer above erosional base....................

Partial thickness of the Wasatch

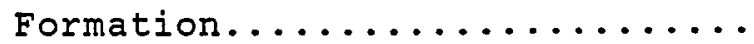


Section $\mathrm{H}$

Section $H$ was measured within the wasatch Formation at SE 1/4, SE 1/4, NE 1/4, sec. 3, T. 13 N., R. 103 W.

Top of section: eroded

\begin{tabular}{cc} 
Unit & Stratigraphic \\
Thickness & Location \\
(Meters) & (Meters) \\
\hline
\end{tabular}

7. Sandstone, light-gray, massive, thin-to thick-bedded, cross-stratified, "unstratified," medium-grained; mud pebble layer overlies 7.0

17.9 erosional base..............

6. Silty claystone, light-gray.

2.6

15.3

5. Sandstone, light-gray, thinbedded, ripple-stratified, finegrained.................

4. Silty claystone, light-gray.

0.6

14.7

3. Sandstone, light-gray, massive, thin- to thick-bedded, cross-stratified, convoluted, medium-grained; mud pebble layer overlies erosional base........

$\begin{array}{ll}5.4 & 7.8\end{array}$

2. Silty claystone, medium-

dark-gray................

1.5

13.2

1. Sandstone, light-gray, thinbedded, ripple-stratified, finegrained..................

Partial thickness of the Wasatch

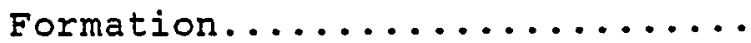

Base of section: overlies light-gray silty claystone of the Wasatch Formation.

Section $\mathrm{J}$ 
Section $J$ was measured within the Wasatch Formation from SE $1 / 4, \mathrm{NE} 1 / 4, \mathrm{NW} 1 / 4$, sec. $2, \mathrm{~T} .13 \mathrm{~N}, \mathrm{R} .103 \mathrm{~W}$. to NE 1/4, NW 1/4, NE 1/4, sec. 2, T. 13 N., R. 103 W.

Top of section: overlain by light-gray silty claystone of the Wasatch Formation.

$\begin{array}{cc}\text { Unit } & \text { Stratigraphic } \\ \text { Thickness } & \text { Location } \\ \text { (Meters) } & \text { (Meters) }\end{array}$

4. Sandstone, light-gray, massive, thick-bedded, crossstratified, "unstratified", ripple-stratified at top, medium-grained; mud pebble layer overlies erosional base........

$14.7 \quad 64.6$

3. Silty claystone, light-gray to light olive-gray; interbedded with sandstone, light-gray, flaggy, very thin- to thinbedded, ripple-stratified, locally cross-stratified, burrowed, fine-grained..........

2. Sandstone, light-gray, massive, thin- to thick-bedded, cross-stratified, convoluted, medium-grained; mud pebble layer overlies erosional base........

6.2

1. Sandstone, light-gray, massive, thin- to thick-bedded, cross-stratified, convoluted, medium-grained; mud pebble layer overlies erosional base........

Partial thickness of the Wasatch Formation................
6.2
0.0

Base of section: section overlies light-gray, thin-bedded, ripple-stratified sandstone of the Wasatch Formation.

Section $K$ 
Section $K$ was measured within the wasatch Formation at SW $1 / 4$, SW 1/4, SE 1/4, sec. 35, T. 14 N., R. 103 W.

Top of section: eroded

\begin{tabular}{cc} 
Unit & Stratigraphic \\
Thickness & Location \\
(Meters) & (Meters) \\
\hline
\end{tabular}

2. Sandstone, light-gray, massive, thick-bedded, crossstratified, convoluted, ripplestratified at top, mediumgrained; mud pebble layer overlies erosional base........ 17.9 7.2

1. Sandstone, light-gray, massive, thin- to thick-bedded, cross-stratified, mediumgrained; erosional base......... 7.2 0.0

Partial thickness of the Wasatch

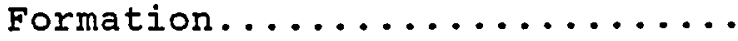
25.1

Base of section: covered.

Section I

Section $L$ was measured within the Wasatch Formation from $N E 1 / 4, S W 1 / 4, S E 1 / 4$, sec. 3, T. $13 \mathrm{~N} ., \mathrm{R} .103 \mathrm{~W}$. to NW 1/4, SE 1/4, SE 1/4, sec. 3, T. 13 N., R. $103 \mathrm{~W}$.

Top of section: eroded

\begin{tabular}{cc}
$\begin{array}{c}\text { Unit } \\
\text { Thickness }\end{array}$ & $\begin{array}{c}\text { Stratigraphic } \\
\text { Location } \\
\text { (Meters) }\end{array}$ \\
\hline
\end{tabular}

5. Sandstone, light-gray, massive, thin- to thick-bedded, cross-stratified, ripplestratified at top, mediumgrained; mud pebbles overlie erosional base............... 
4. Silty claystone, light-gray to greenish-gray; interbedded with sandstone, light-gray, very thin- to thin-bedded, ripplestratified, burrowed, mediumgrained..................

3. Sandstone, light-gray, massive, thin- to thick-bedded, cross-stratified, convoluted, "unstratified," medium-grained; mud pebbles overlie erosional

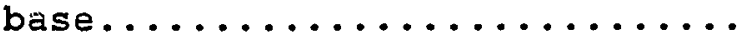

2. Silty claystone, greenishgray; interbedded with sandstone, light-gray, flaggy, very thin-bedded, ripplestratified, burrowed, fine-

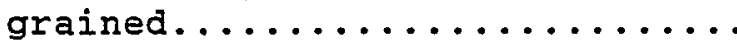

1. Sandstone, light-gray, massive, thin- to thick-bedded, cross-stratified, convoluted, "unstratified," , mediumgrained, locally very coarse- to coarse-grained near base; mud pebble layer overlies erosional base....................

Partial thickness of the Wasatch

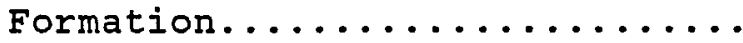

Base of section: covered

Section $M$

Section $M$ was measured within the Wasatch Formation from SW 1/4, SE 1/4, NE 1/4, sec. 2, T. $13 \mathrm{~N} ., \mathrm{R} .103 \mathrm{~W}$, to NW 1/4, NW 1/4, NW 1/4, sec. 1, T. 13 N., R. 103 W.

Top of section: eroded

Unit Thickness (Meters)
Stratigraphic

Location

(Meters) 
8. Silty claystone, light-gray to greenish-gray; interbedded with sandstone, light-gray, flaggy, thin-bedded, ripplestratified, burrowed, medium- to fine-grained..............

7. Sandstone, light-gray, massive, thin- to thick-bedded, cross-stratified,

"unstratified," medium-grained; mud pebble layer overlies erosional base.............

6. Silty claystone, lightolive-gray; interbedded with sandstone, light-gray, very thin- to thin-bedded, ripplestratified, burrowed, medium- to fine-grained...............

5. Sandstone, light-gray, massive, thin- to thick-bedded, cross-stratified, convoluted, "unstratified," ripplestratified at top, mediumgrained; mud pebble layer overlies erosional base........

4. Silty claystone, light-gray to greenish-gray; interbedded with sandstone, light-gray, platy, thin-bedded, ripplestratified, burrowed, medium- to fine-grained..............

3. Sandstone, light-gray, massive, thin- to thick-bedded, cross-stratified, convoluted, medium-grained; erosional base..

2. Silty claystone, light-gray; interbedded with sandstone, light-gray, thin-bedded, ripplestratified, fine-grained.......
6.8
2.3 
1. Sandstone, Iight-gray, thinto thick-bedded, cross-

stratified, ripple-stratified at top, medium-grained; mud pebble layer overlies base .......... $2.3 \quad 0.0$

Partial thickness of the Wasatch

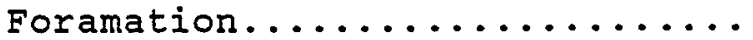

Base of section: covered

Section $\mathbf{N}$

Section $N$ was measured within the Wasatch Formation from NE $1 / 4, \mathrm{SW} 1 / 4, \mathrm{NW} 1 / 4$ sec. $1, \mathrm{~T} .13 \mathrm{~N} ., \mathrm{R} .103 \mathrm{~W}$. to SE 1/4, NW 1/4, NW 1/4, sec. 1, T. 13 N., R. 103 W.

Top of section: eroded

\begin{tabular}{cc} 
Unit & Stratigraphic \\
Thickness & Location \\
(Meters) & (Meters) \\
\hline
\end{tabular}

7. Sandstone, light-gray, massive, thin-to thick-bedded, cross-stratified, convoluted, ripple-stratified at top, medium-grained; mud pebble layer overlies erosional base..........

6. Silty claystone, light-gray; interbedded with sandstone, light-gray, flaggy, thin-bedded, ripple-stratified,

"unstratified," burrowed, medium-grained.............

5. Sandstone, Iight-gray, thinbedded, ripple-stratifed, finegrained................. 
3. Sandstone, light-gray, very thin- to thin-bedded, ripplestratified, locally crossstratified, fine- to very finegrained.................. $2.2 \quad 25.3$

2. Silty claystone, lightolive-gray; interbedded with sandstone, light gray, thinbedded, ripple-stratified,

burrowed, fine-grained........

1. Sandstone, light-gray, massive, thin-to thick-bedded, cross-stratified,

"unstratified," southwarddipping second order contacts, medium-grained; mud pebble layer overlies erosional base.........

Partial thickness of the Wasatch

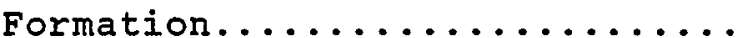
13.8
0.0

Base of section: section overlies light-gray claystone of the Wasatch Formation.

Section 0

Section 0 was measured within the Wasatch Formation from SW 1/4, NW 1/4, NE 1/4, sec. 1, T. $13 \mathrm{~N} ., \mathrm{R} .103 \mathrm{~W}$. to NE 1/4, NE 1/4, NW 1/4, sec. 1, T. $13 \mathrm{~N} ., \mathrm{R} .103 \mathrm{~W}$.

Top of section: covered

\begin{tabular}{cc}
$\begin{array}{c}\text { Unit } \\
\text { Thickness }\end{array}$ & $\begin{array}{c}\text { Stratigraphic } \\
\text { Location } \\
\text { (Meters) }\end{array}$ \\
\hline
\end{tabular}

4. Sandstone, light-gray,

massive, thin- to thick-bedded, cross-stratified,

"unstratified," ripplestratified at top, mediumgrained; mud pebbles overlie erosional base. 
3. Sandstone, light-gray,

massive, thin- to thick-bedded, cross-stratified,

"unstratified," ripple-

stratified at top, medium-

grained; mud pebble layer

overlies erosional base........

$9.3 \quad 28.6$

2. Silty claystone, light-gray; interbedded with sandstone,

light-gray, thin-bedded, ripplestratified, "unstratified,"

locally burrowed, medium- to

fine- grained...............

$\begin{array}{ll}27.9 & 0.7\end{array}$

1. Sandstone, light-gray, thinbedded, ripple-stratified, finegrained..................

Partial thickness of the Wasatch

Formation................

48.6

Base of section: section overlies light-gray silty claystone of the Wasatch Formation.

Section $P$

Section $P$ was measured within the Wasatch Formation from SE 1/4, NW 1/4, NE 1/4, sec. 1, T. $13 \mathrm{~N} ., \mathrm{R} .103 \mathrm{~W}$. to NW 1/4, SW 1/4, NW 1/4, sec. $6, T .13$ N., R. $102 \mathrm{~W}$.

Top of section: eroded

Unit

Thickness

(Meters)
Stratigraphic
Location
(Meters)

8. Sandstone, light-gray, thin-

bedded, ripple-stratified,

locally cross-stratified,

"unstratified," medium-grained..

2.2

78.4 
7. Silty claystone, greenishgray; interbedded with sandstone, light-gray, thinbedded, ripple-stratified, medium-grained.............

6. Sandstone, light-gray, very thin-bedded, ripple-stratified, gradational base, medium- to very fine-grained...........

$0.6 \quad 65.6$

5. Claystone, light-gray......

3.8

61.8

4. Sandstone, light-gray, very thin-bedded, ripple-stratified, medium-grained.............

3. Silty claystone, greenishgray; interbedded with sandstone, light-gray, very thin- to thin-bedded, ripplestratified, "unstratified," burrowed, medium-to fine-

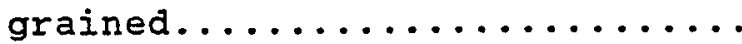

2. Sandstone, light-gray, massive, thick-bedded, crossstratified, "unstratified," medium-grained; mud pebble layer overlies erosional base........

1. Sandstone, light-gray, massive, thick-bedded, crossstratified, "unstratified," medium-grained; mud pebble layer overlies erosional base........
8.3
0.0

Partial thickness of the Wasatch

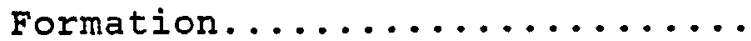
80.6

Base of section: section overlies light-gray silty claystone of the Wasatch Formation.

Section $Q$

Section $Q$ was measured within the Wasatch Formation 
from NE 1/4, NW 1/4, NE 1/4, sec. 1, T. $13 \mathrm{~N} ., \mathrm{R} .103 \mathrm{~W}$. to $\mathrm{SE} 1 / 4, \mathrm{SW} 1 / 4, \mathrm{SE} 1 / 4$, sec. $36, T .14 \mathrm{~N} ., \mathrm{R}, 103 \mathrm{~W}$.

Top of section: covered

\begin{tabular}{cc} 
Unit & Stratigraphic \\
Thickness & Location \\
(Meters) & (Meters) \\
\hline
\end{tabular}

3. Sandstone, Iight-gray, massive, thick-bedded, crossstratified, medium-grained;

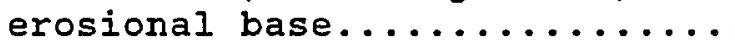

2. Silty claystone, light-

olive-gray................

2.6

1. Sandstone, light-gray, thin-

bedded, ripple-stratified,

locally cross-stratified,

medium-grained, fine- to very

fine-grained at base..........

2.6

0.0

Partial thickness of the Wasatch

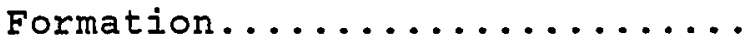

13.6

Base of section: section overlies light-gray silty claystone of the Wasatch Formation.

Section $R$

Section $R$ was measured within the Wasatch Formation at $\mathrm{NE} 1 / 4, \mathrm{SE} 1 / 4, \mathrm{NE} 1 / 4$, sec. $1, \mathrm{~T} .13 \mathrm{~N} ., \mathrm{R} .103 \mathrm{~W}$.

Top of section: overlain by light-gray silty claystone of the Wasatch Formation.

$\begin{array}{cc}\text { Unit } & \text { Stratigraphic } \\ \text { Thickness } & \text { Location } \\ \text { (Meters) } & \text { (Meters) }\end{array}$

3. Sandstone, light-gray, very thin-bedded, ripple-stratified, fine-grained...............

$0.9 \quad 13.5$


2. Silty claystone, light-

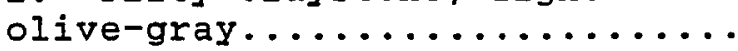

2.8

10.7

1. Sandstone, light-gray,

massive, thin- to thick-bedded,

cross-stratified, ripple-

stratified at top, medium-

grained; mud pebble layer

overlies erosional base........

10.7

0.0

Partial thickness of the Wasatch

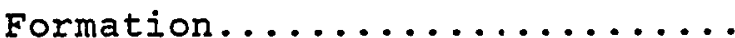

14.4

Base of section: section overlies light-gray silty claystone of the Wasatch Formation.

Section $\mathbf{S}$

Section $S$ was measured within the Wasatch Formation

from $S E 1 / 4, S E 1 / 4, N E 1 / 4$, sec. $1, T .13 \mathrm{~N} ., \mathrm{R} .103 \mathrm{~W}$. to SW 1/4, SW 1/4, NW 1/4, sec. 6, T. 13 N., R. 102 W.

Top of section: eroded

\begin{tabular}{cc} 
Unit & Stratigraphic \\
Thickness & Location \\
(Meters) & (Meters) \\
\hline
\end{tabular}

8. Silty claystone, greenishgray; interbedded with sandstone, light-gray, flaggy, very thin-bedded, ripplestratified, burrowed, fine-

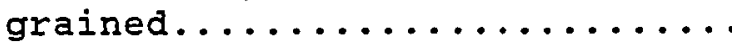

0.9

56.6

7. Sandstone, light-gray, massive, thick-bedded, crossstratified, "unstratified," medium-grained; mud pebble layer overlies erosional base........

10.5

46.1 
6. Silty claystone, lightolive-gray; interbedded with sandstone, light-gray, thinbedded, ripple-stratified, burrowed, medium- to fine-

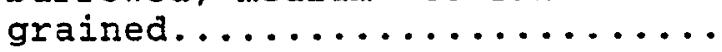

11.0

35.1

5. Sandstone, light-gray, massive, thin- to thick-bedded, cross-stratified, mediumgrained; mud pebble layer overlies erosional base........

$7.5 \quad 27.6$

4. Silty claystone, light-gray; interbedded with sandstone, light-gray, slabby, thin-bedded, ripple-stratified, locally cross-stratified, medium-

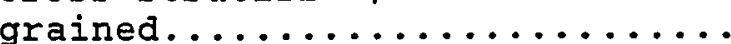

$9.4 \quad 18.2$

3. Sandstone, light-gray, thinbedded, ripple-stratified,

"unstratified," medium-grained..

$2.6 \quad 15.6$

2. Silty claystone, light-gray.

$2.5 \quad 13.1$

1. Sandstone, light-gray, massive, thin- to thick-bedded, cross-stratified,

"unstratified," medium-grained, fine- to very fine-grained at top: mud pebbles overlie

erosional base..............

$13.1 \quad 0.0$

Partial thickness of the Wasatch Formation...............

57.5

Base of section: covered

Section $\mathrm{T}$

Section $T$ was measured within the Wasatch Formation from NW 1/4, NE 1/4, SW 1/4, sec. 6, T. $13 \mathrm{~N} ., \mathrm{R} .102 \mathrm{~W}$. to SE $1 / 4, \mathrm{SW} 1 / 4, \mathrm{NW} 1 / 4$, sec. 6, T. 13 N., R. $102 \mathrm{~W}$. 
Top of section: eroded

$\begin{array}{cc}\text { Unit } & \text { Stratigraphic } \\ \text { Thickness } & \text { Location } \\ \text { (Meters) } & \text { (Meters) }\end{array}$

5. Sandstone, light-gray, very thin-bedded, ripple-stratified, fine-grained..............

0.6

22.8

4. Silty claystone, light-gray to greenish-gray; interbedded with sandstone, light-gray, flaggy, thin-bedded, ripplestratified, burrowed, medium- to fine-grained..............

18.6

4.2

3. Sandstone, light-gray, thinbedded, ripple-stratified, burrowed, fine-grained.........

0.9

3.3

2. Silty claystone, light-

olive-gray.................

1.5

1.8

1. Sandstone, light-gray, thinbedded, ripple-stratified, "unstratified," burrowed, medium-grained, fine- to very fine-grained at base...........

Partial thickness of the Wasatch

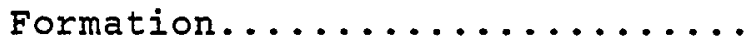

$1.8 \quad 0.0$

Base of section: section overlies light-gray silty claystone of the Wasatch Formation.

Section U

Section $U$ was measured within the wasatch Formation at SW 1/4, NW 1/4, SW 1/4, sec. 6, T. 13 N., R. 102 W.

Top of section: eroded

$\begin{array}{cc}\text { Unit } & \text { Stratigraphic } \\ \text { Thickness } & \text { Location }\end{array}$


(Meters) (Meters)

3. Sandstone, light-gray, massive, thin- to thick-bedded, cross-stratified,

"unstratified," ripple-

stratified at top, medium-

grained; mud pebbles overlie

erosional base..............

$\begin{array}{ll}11.8 & 4.8\end{array}$

2. Claystone, light-olive-gray,

locally carbonaceous...........

$3.6 \quad 1.2$

1. Sandstone, light-gray,

"unstratified," medium-grained;

sharp base................

$1.2 \quad 0.0$

Partial thickness of the Wasatch

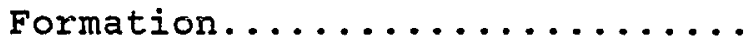

16.6

Base of section: section overlies light-gray silty claystone of the Wasatch Formation.

Section $V$

Section $V$ was measured within the Wasatch Formation from SE 1/4, NE $1 / 4$, SW 1/4, sec. 6, T. $13 \mathrm{~N} ., \mathrm{R} .102 \mathrm{~W}$. to NE 1/4, NW 1/4, SW 1/4, sec. $6, T .13$ N., R. 102 W.

Top of section: eroded

\begin{tabular}{cc} 
Unit & Stratigraphic \\
Location \\
(Meters) & (Meters) \\
\hline
\end{tabular}

9. Silty claystone, mediumlight-gray; interbedded with sandstone, light-gray, thinbedded, ripple-stratified, burrowed, fine-grained.........

1.3

46.4 
8. Sandstone, light-gray, thinbedded, ripple-stratified, locally cross-stratified, "unstratified," gradational base, medium- to very fine-

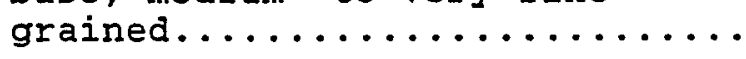

7. Silty claystone, mediumgray; interbedded with sandstone, light-gray, thinbedded, ripple-stratified, finegrained.................

6. Iimestone, medium-gray to light-brown, "unstratified," pebble-size bioclasts in a micritic matrix.............

5. Silty claystone, lightolive-gray...............

4. Sandstone, light-gray, thinbedded, ripple-stratified, fine-



3. Silty claystone, lightolive-gray................

2. Sandstone, light-gray, massive, thin- to thick-bedded, cross-stratified, ripplestratified at top, mediumgrained; southeast-dipping second order contacts, mud pebble layer overlies erosional

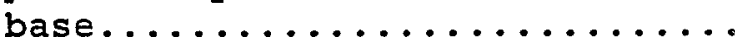

1. Silty claystone, lightolive-gray; interbedded with sandstone, light-gray, thinbedded, ripple-stratified, medium- to fine-grained.........

Partial thickness of the Wasatch

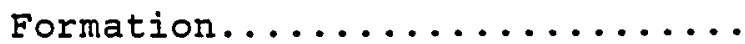

Base of section: section overlies coal and carbonaceous shale of the Wasatch Formation. 


\section{Section $W$}

Section $W$ was measured within the Wasatch Formation from NW 1/4, SW 1/4, SE 1/4, sec. 6, T. $13 \mathrm{~N} ., \mathrm{R} .102 \mathrm{~W}$. to SW 1/4, NE 1/4, SE 1/4, sec. 6, T. 13 N., R. $102 \mathrm{~W}$.

Top of section: section overlain by light-gray, thin-bedded, ripple-stratified sandstone of the Wasastch Formation.

\begin{tabular}{|c|c|}
\hline+ & raphi \\
\hline $\begin{array}{c}\text { Thickness } \\
\text { (Meters) }\end{array}$ & $\begin{array}{l}\text { Location } \\
\text { (Meters) }\end{array}$ \\
\hline
\end{tabular}

9. Claystone, light-gray......

3.7

46.1

8. Sandstone, light-gray,

massive, thin- to thick-bedded, cross-stratified, ripplestratified at top,

"unstratified," medium- to finegrained; mud pebble layer

overlies erosional base, gradational upper contact.......

7. Sandstone, light-gray, massive, thin- to thick-bedded, cross-stratified, convoluted, medium-grained; mud pebble layer overlies erosional base........

12.2

6. Claystone, light olive-gray.

5. Limestone, medium-gray "unstratified," gastropod fossils and bioclasts in a microcrystalline matrix........

4. Silty claystone, light-gray, locally carbonaceous; interbedded with sandstone, light-gray, thin-bedded, ripplestratified, burrowed, fine-

grained.................

$8.3 \quad 10.7$

3. Coal and carbonaceous shale, black to brownish-gray.........

$0.5 \quad 10.2$


2. Limestone, medium-light-

gray, whole gastropod fossils

and bioclasts in a

microcrystalline matrix........

0.5

9.7

1. Silty claystone, light-gray;

interbedded with sandstone,

light-gray, thin-bedded, ripple-

stratified, "unstratified,"

burrowed, medium- to very fine-

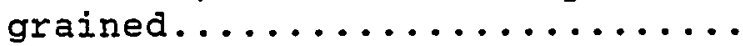

$9.7 \quad 0.0$

Partial thickness of the wasatch

Formation................

49.8

Base of section: section overlies light-gray silty claystone of the Wasatch Formation.

\section{Section $x$}

Section $X$ was measured within the Wasatch Formation from NE 1/4, NW 1/4, NW 1/4, sec. 7, T. $13 \mathrm{~N} ., \mathrm{R} .102 \mathrm{~W}$. to NW 1/4, SW 1/4, SW 1/4, sec. 5, T. 13 N., R. 102 W.

Top of section: eroded

\begin{tabular}{cc} 
Unit & Stratigraphic \\
Thickness & Location \\
(Meters) & (Meters) \\
\hline
\end{tabular}

9. Claystone, light-gray to greenish-gray, locally carbonaceous; interbedded with sandstone, light-gray, slabby, thin-bedded, ripple-stratified, fine-grained; interbedded with limestone, very light-gray to medium-light-gray, microcrystalline............

8. Limestone, pale-yellowishorange, microcrystalline.......

0.3

83.65 
7. Silty claystone, greenishgray to pale-red; interbedded with sandstone, light-gray, thin-bedded, ripple-stratified, burrowed, medium- to finegrained; interbedded with Iimestone, pale-yellowish-brown, bioclasts in a microcrystalline matrix.................

6. Sandstone, light-gray, massive, thin- to thick-bedded, cross-stratified, ripplestratified at top, "unstratified," medium- to very fine-grained; erosional base, gradational upper contact.......

5. Silty claystone, light-gray to greenish-gray; interbedded with sandstone, light-gray, thin-bedded, ripple-stratified, locally cross-stratified, burrowed, medium- to finegrained; interbedded with limestone, medium-gray. gastropod bioclasts in a

4. Coal, black, carbonaceous...

3. Limestone, pale-yellowishbrown, bioclasts in a

microcrystalline matrix........

2. Silty claystone and clayey siltstone, light-gray to moderate-brown; interbedded with sandstone, light-gray, slabby, thin-bedded, ripple-stratified, medium- to very fine-grained; interbedded with limestone, pale-yellowish-brown, ostracode

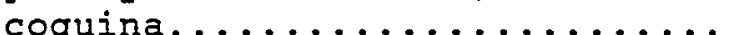

1. Sandstone, light-gray, massive, thin- to thick-bedded, cross-stratified, 
Partial thickness of the Wasatch

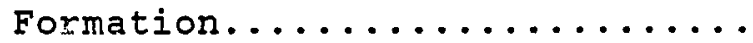

Base of section: covered

Section $Y$

Section $Y$ was measured within the Wasatch Formation to the base of the Luman Tongue of the Green River Formation from NW 1/4, NE 1/4, NE 1/4, sec. $7, T .13 \mathrm{~N} ., \mathrm{R} .102 \mathrm{~W}$. to SW 1/4, SW 1/4, NW 1/4, sec. 8, T. 13 N., R. 102 W.

Top of section: overlain by light-gray sandstone of the Luman Tongue of the Green River Formation.

$\begin{array}{cc}\text { Unit } & \text { Stratigraphic } \\ \text { Thickness } & \text { Location } \\ \text { (Meters) } & \text { (Meters) }\end{array}$

3. Silty claystone, greenishgray to pale-red, locally carbonaceous; interbedded with sandstone, light-gray, thinbedded, ripple-stratified, medium- to very fine-grained....

47.0 29.2

2. Limestone, dark-gray to pale-yellowish-brown, whole gastropod fossils and bioclasts in a microcrystalline matrix....

0.3 28.9

1. Silty claystone, light-gray to pale-red, locally carbonaceous; interbedded with sandstone, light-gray, flaggy, thin-bedded, ripple-stratified, medium- to fine-grained......... 28.9 0.0

Partial thickness of the Wasatch

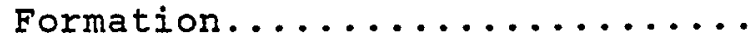

Base of section: overlies light-gray sandstone of the Wasatch Formation. 
Section $\mathbf{z}$

Section $Z$ was measured within the Wasatch Formation from NW 1/4, SE 1/4, SE 1/4, sec. 6, T. 13 N., R. 102 W. to SE 1/4, NE 1/4, SE $1 / 4$, sec. 6, T. 13 N., R. 102 W.

Top of section: section overlain by light-gray silty claystone of the Wasatch Formation.

$\begin{array}{cc}\text { Unit } & \text { Stratigraphic } \\ \text { Thickness } & \text { Location } \\ \text { (Meters) } & \text { (Meters) }\end{array}$

4. Silty claystone, greenishgray; interbedded with sandstone, light-gray, thinbedded, ripple-stratified, "unstratified," medium- to fine-

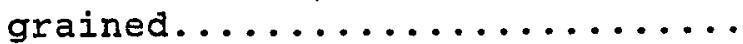
2.3
18.4

3. Limestone, medium-dark-gray, whole gastropod fossils and biocalsts in a microcrystalline

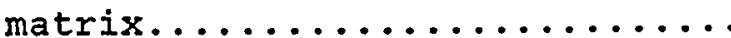

2. Silty claystone, light-gray, locally carbonaceous..........

10.7

7.5

1. Sandstone, light-gray, massive, thick-bedded, crossstratified, "unstratified," ripple-stratified at top, medium-grained; south-dipping second order contacts, mud pebbles above erosional base....

7.5 0.0

Partial thickness of the Wasatch

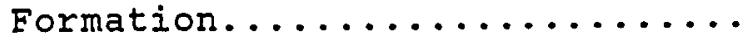

Base of section: section overlies light-gray claystone of the Wasatch Formation. 
Section $A A$

Section $A A$ was measured within the Wasatch Formation from SW $1 / 4$, NE $1 / 4$, SW $1 / 4$, sec. 2 , T. $13 \mathrm{~N} ., \mathrm{R} .103 \mathrm{~W}$. to NE 1/4, SW 1/4, SW 1/4, sec. 2, T. 13 N., R. $103 \mathrm{~W}$.

Top of section: eroded

\begin{tabular}{cc}
$\begin{array}{c}\text { Unit } \\
\text { Thickness }\end{array}$ & $\begin{array}{c}\text { Stratigraphic } \\
\text { (Meters) }\end{array}$ \\
\hline
\end{tabular}

5. Sandstone, light-gray, massive, thin- to thick-bedded, cross-stratified,

"unstratified," ripple-

stratified at top, , mediumgrained; mud pebble layer overlies erosional base........

12.3

44.4

4. Silty claystone and clayey siltstone, light-gray: interbedded with sandstone, light-gray, slabby, thin-bedded, ripple-stratified, fine-grained.

10.8

33.6

3. Sandstone, light-gray, massive, thin- to thick-bedded, cross-stratified, ripplestratified at top, mediumgrained; mud pebble layer overlies erosional base........

11.4

22.2

2. Silty claystone, greenishgray; interbedded with sandstone, light-gray, thinbedded, ripple-stratified, burrowed, medium- to fine-

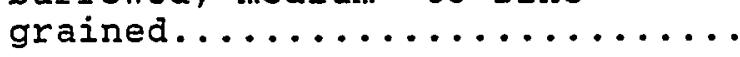

13.2

9.0

1. Sandstone, light-gray, massive, thin- to thick-bedded, cross-stratified,

"unstratified," medium-grained. .

9.0

0.0 
Partial thickness of the Wasatch

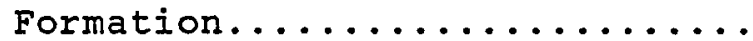

56.7

Base of section: covered

Section CC

Section CC was measured within the Wasatch Formation at SW 1/4, NE 1/4, SE 1/4, sec. 1, T. 13 N., R. $103 \mathrm{~W}$.

Top of section: eroded

$\begin{array}{cc}\text { Unit } & \text { Stratigraphic } \\ \text { Thickness } & \text { Location } \\ \text { (Meters) } & \text { (Meters) }\end{array}$

3. Sandstone, light-gray, massive, thin- to thick-bedded, cross-stratified,

"unstratified," medium-grained; mud pebble layer overlies

erosional base..............

$5.8 \quad 28.3$

2. Silty claystone and clayey

siltstone, greenish-gray;

interbedded with sandstone,

light-gray, thin-bedded, ripple-

stratified, locally cross-

stratified, "unstratified,"

medium- to very fine-grained....

20.9

7.3

1. Sandstone, light-gray, massive, thin- to thick-bedded, cross-stratified, ripple-

stratified at top, medium-

grained.................

$\begin{array}{ll}7.3 & 0.0\end{array}$

Partial thickness of the Wasatch

Formation................

34.0

Base of section: covered 


\section{Section $E E$}

Section $E E$ was measured within the Wasatch Formation at SE 1/4, SW 1/4, NW 1/4, sec. 1, T. 13 N., R. $103 \mathrm{~W}$.

Top of section: eroded

$\begin{array}{cc}\text { Unit } & \text { Stratigraphic } \\ \text { Thickness } & \text { Location } \\ \text { (Meters) } & \text { (Meters) }\end{array}$

3. Sandstone, light-gray, massive, thin- to thick-bedded, cross-stratified, convoluted, "unstratified," medium-grained; mud pebble layer overlies

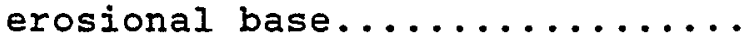

6.9

14.2

2. Silty claystone, light-gray; interbedded with sandstone, light-gray, slabby, thin-bedded, ripple-stratified, burrowed, fine- to very fine-grained......

9.2

5.0

1. Sandstone, light-gray, massive, thin- to thick-bedded, cross-stratified,

"unstratified," medium-grained. .

5.0

0.0

Partial thickness of the Wasatch

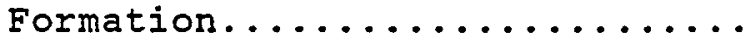

21.1

Base of section: covered

\section{Field Area III}

Field Area III is located within the Wilkins Peak 7.5 minute quadrangle, Sweetwater County, Wyoming. Sections were measured in field area III from the Fort Union - 
Wasatch boundary, through the Wasatch Formation, to the base of the Luman Tongue of the Green River Formation.

Stratigraphic sections $A$ through $Q$ were measured in sec. 31, T. 17 N., R. 105 W.; sec. 34,35 and 36, T. 17 N., R. $106 \mathrm{~W}$. and sec. 1,2 and 3, T. $16 \mathrm{~N} ., \mathrm{R} .106 \mathrm{~W}$. The locations of stratigraphic sections are given in Figure 24.

Section A

Section $A$ was measured within the Wasatch Formation from SW 1/4, NW 1/4, SW 1/4, sec. 31, T. $17 \mathrm{~N} ., \mathrm{R} .105 \mathrm{~W}$. to SW 1/4, NE 1/4, NW 1/4, sec. 1, T. 16 N., R. 106 W.

Top of section: eroded

Unit Stratigraphic

Thickness Location

(Meters) (Meters)

4. Sandstone, light-gray,

massive, thin- to thick-bedded, cross-stratified,

"unstratified," medium-grained;

southwest-dipping second-order

contacts, erosional base........

14.8

41.4

3. Silty claystone and clayey

siltstone, greenish-gray;

interbedded with sandstone,

light-gray, flaggy to slabby,

thin-bedded, ripple-stratified,

"unstratified," burrowed,

medium-to very fine-grained.....

13.2

28.2

2. Sandstone, weathers pale-

red, massive, thin- to thick-

bedded, cross-stratified,

convoluted, "unstratified,"

medium-grained; southwest-

dipping second order conatacts,

mud pebbles overlie erosional

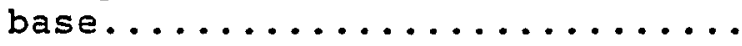

9.6

$18 \cdot 6$ 


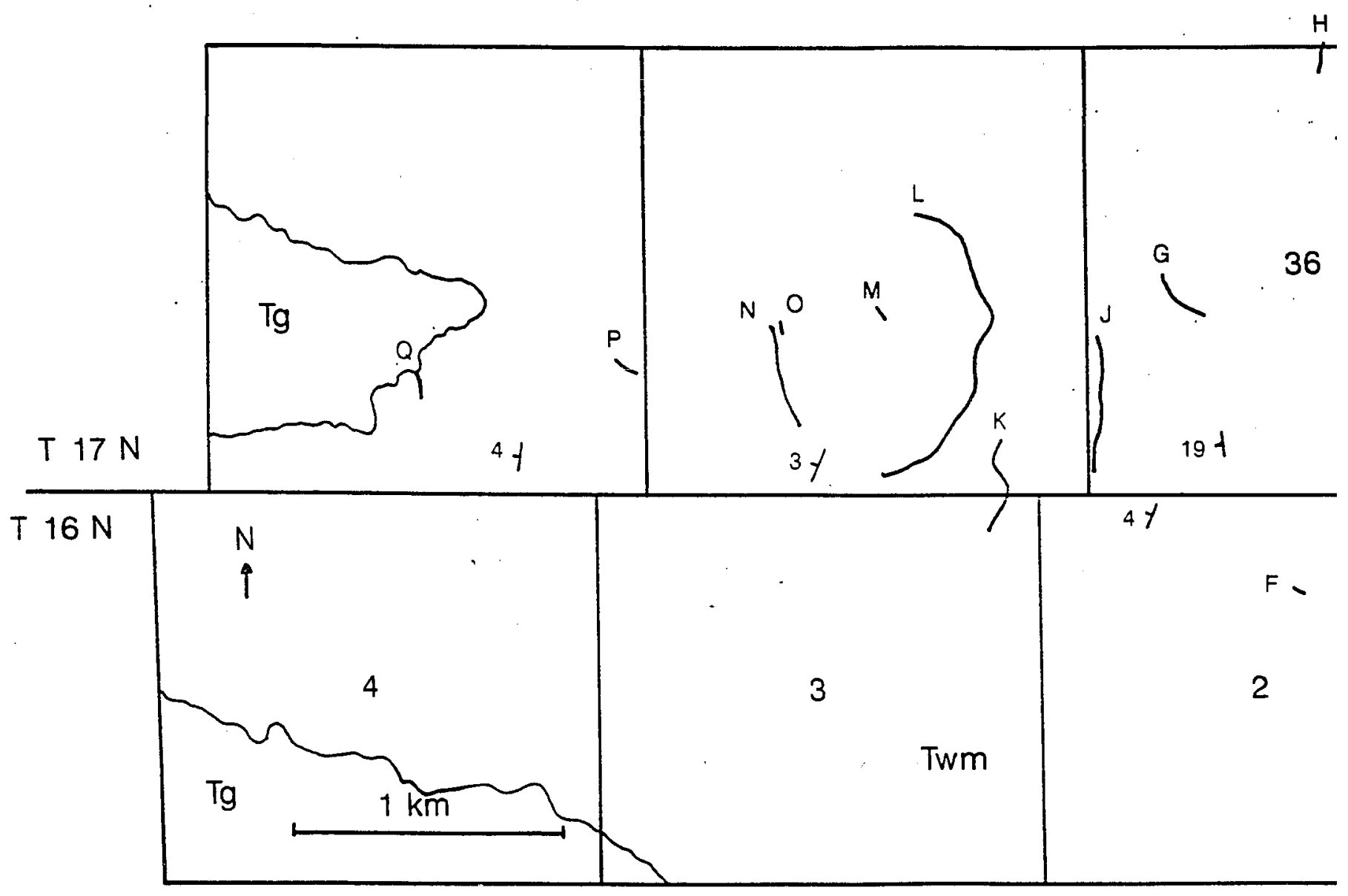

Figure 24. Location map for measured sections in field area III. The geologic base map depicts the Fort Union Formation (Tfu), Wasatch Formation (Twm), and Green River Formation ( $\mathrm{Tg}$ ) (modified from Love and Christiansen, 1985). 


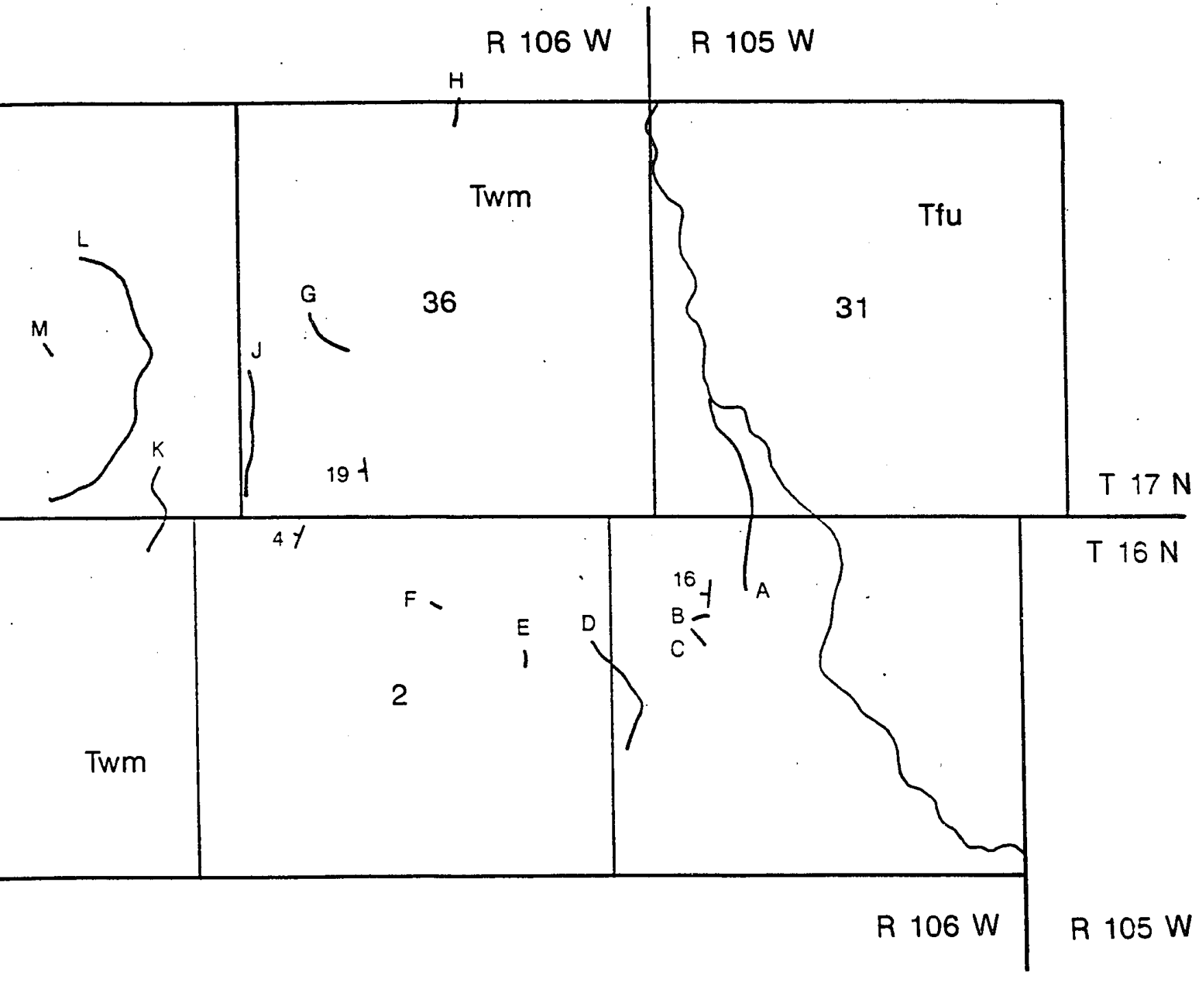

ons in field

it Union een River

sen, 1985). 
1. Silty claystone, greenish-

gray; interbedded with sandstone, weathers pale-red, thin-bedded, ripple-stratified, "unstratified," fine-grained.... $18.6 \quad 0.0$

Partial thickness of the Wasatch

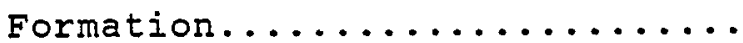

56.2

Base of section: section overlies light-gray silty claystone of the Fort Union Formation.

\section{Section B}

Section $B$ was measured within the Wasatch Formation at $\mathrm{NW} 1 / 4, \mathrm{SE} 1 / 4, \mathrm{NW} 1 / 4$, sec. 1, T. $16 \mathrm{~N} ., \mathrm{R} .106 \mathrm{~W}$.

Top of section: eroded

\begin{tabular}{cc} 
Unit & Stratigraphic \\
Thickness & Location \\
(Meters) & (Meters) \\
\hline
\end{tabular}

4. Sandstone, light-gray, massive, thin- to thick-bedded, cross-stratified, ripplestratified at top, mediumgrained; mud pebble layer overlies erosional base.........

3. Claystone, greenish-gray, locally pale-red; interbedded with sandstone, light-gray, "unstratified," burrowed, fine-

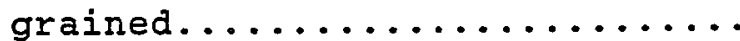

2. Sandstone, light-gray, "unstratified," burrowed, medium-grained..............

1. Silty claystone, light-gray to greenish-gray, locally palered; interbedded with sandstone, light-gray, locally weathers pale-red, thin-bedded, ripplestratified, "unstratified," medium-grained............. 
Partial thickness of the Wasatch

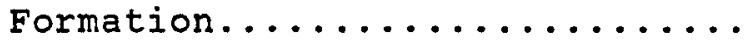

44.1

Base of section: section overlies light-gray, thin-bedded, ripple-stratified sandstone of the Wasatch Formation.

Section C

Section $C$ was measured within the Wasatch Formation at $\mathrm{NE} 1 / 4, \mathrm{SW} 1 / 4, \mathrm{NW} 1 / 4$, sec. 1, T. $16 \mathrm{~N} ., \mathrm{R} .106 \mathrm{~W}$.

Top of section: eroded

\begin{tabular}{cc}
$\begin{array}{c}\text { Unit } \\
\text { Thickness }\end{array}$ & $\begin{array}{c}\text { Stratigraphic } \\
\text { Location } \\
\text { (Meters) }\end{array}$ \\
\hline
\end{tabular}

8. Sandstone, light-gray, massive, thick-bedded, crossstratified, medium-grained; mud pebble layer overlies erosional

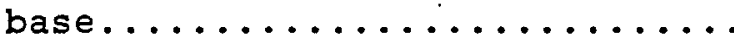

$7.3 \quad 51.5$

7. Silty claystone and clayey

siltstone, light-gray to

greenish-gray; interbedded with

sandstone, light-gray, flaggy to

slabby, ripple-stratified,

"unstratified," burrowed, fine-

grained.................

$\begin{array}{ll}16.7 & 34.8\end{array}$

6. Sandstone, light-gray,

"unstratified," fine- to very

fine-grained; gradational base..

$2.0 \quad 32.8$

5. Silty claystone, greenish-

gray..................

$3.2 \quad 29.6$

4. Sandstone, light-gray, slabby, thin-bedded, ripplestratified, locally crossstratified, fine-grained....... 
3. Silty claystone, greenishgray; interbedded with sandstone, light-gray, locally weathers pale-red, thin-bedded, ripple-stratified,

"unstratified," medium- to fine-

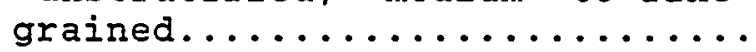

2. Sandstone, light-gray, massive, thin-to thick-bedded, cross-stratified, "unstratified," medium-grained; mud pebbles overly erosional

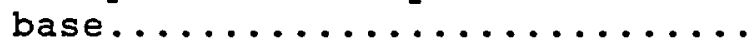

6.1

7.4

1. Silty claystone, greenishgray; interbedded with sandstone, light-gray, weathers pale-red, thin-bedded, ripplestratified, "unstratified," burrowed, medium- to very fine-

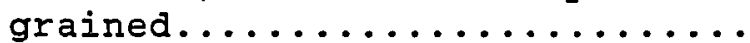
$\begin{array}{ll}7.4 & 0.0\end{array}$

Partial thickness of the Wasatch

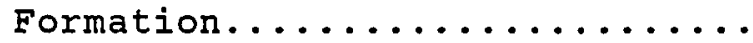
58.8

Base of section: section overlies light-gray, crossstratified sandstone of the Wasatch Formation.

Section D

Section $D$ was measured within the Wasatch Formation from SW 1/4, NW 1/4, SW 1/4, sec. 1, T. 16 N., R. 106 W. to NW 1/4, SW 1/4, NW 1/4, sec. 1, T. 16 N., R. 106 W.

Top of section: eroded

Unit Thickness (Meters)
Stratigraphic Location (Meters) 
8. Sandstone, light-gray, massive, thick-bedded, crossstratified, "unstratified," medium-grained; west-dipping second order contacts, mud pebble layer overlies erosional

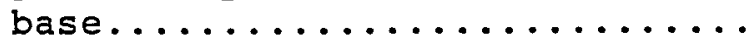

$7.2 \quad 83.9$

7. Silty claystone; light-gray.

7.1

76.8

6. Sandstone, light-gray, massive, thick-bedded, crossstratified, "unstratified," ripple-stratified at top, medium-grained; mud pebble layer overlies erosional base........

$\begin{array}{ll}6.0 & 70.8\end{array}$

5. Sandstone, light-gray, weathers pale-red, massive, thin-to thick-bedded, crossstratified, "unstratified," medium-grained; mud pebble layer overlies erosional base........

4. Silty claystone, greenishgray, locally pale-red;

interbedded with sandstone, light-gray, thin-bedded, ripplestratified, locally crossstratified, "unstratified," burrowed, medium- to very fine-

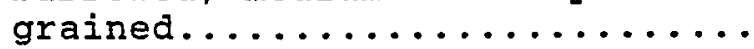

3. Sandstone, light-gray, massive, thick-to very thickbedded, cross-stratified, "unstratified," medium-grained; mud pebble layer overlies erosional base..............

2. Silty claystone, light-gray to greenish-gray, locally palered; interbedded with sandstone, light-gray, locally pale-red, thin-bedded, ripple-stratified, locally cross-stratified, "unstratified," burrowed, medium- to fine-grained........ 
1. Sandstone, light-gray,

massive, thick- to very thick-

bedded, cross-stratified,

"unstratified," west-dipping

second order contacts, medium-

grained; mud pebble layer

overlies erosional base........

11.7

0.0

Partial thickness of the wasatch

Formation.................

91.1

Base of section: overlies light-gray silty claystone of the Wasatch Formation.

\section{Section E}

Section $E$ was measured within the Wasatch Formation at $\mathrm{NW} 1 / 4, \mathrm{SE} 1 / 4, \mathrm{NE} 1 / 4$, sec. 2, T. $16 \mathrm{~N} . \mathrm{R} .106 \mathrm{~W}$.

Top of section: eroded

$\begin{array}{cc}\text { Unit } & \text { Stratigraphic } \\ \text { Thickness } & \text { Location } \\ \text { (Meters) } & \text { (Meters) }\end{array}$

5. Sandstone, light-gray,

weathers pale-red, massive, thin- to thick- bedded, crossstratified, "unstratified," medium-grained; mud pebbles overly erosional base.........

8.3

34.6

4. Silty claystone, greenishgray to pale-red; interbedded with sandstone, light-gray, thin-bedded, ripple-stratified, burrowed, fine-grained.........

3. Sandstone, light-gray, thinbedded, ripple-stratified, "unstratified," medium-grained..

2. Silty claystone, greenishgray.................. 
1. Sandstone, light-gray, weathers pale-red, massive, thin- to thick-bedded, crossstratified, "unstratified," medium-grained; mud pebbles overly erosional base.........

Partial thickness of the Wasatch

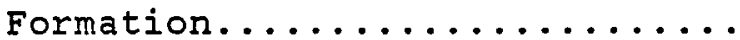

Base of section: section overlies light-gray silty claystone of the Wasatch Formation.

Section $\mathbf{F}$

Section $F$ was measured within the Wasatch Formation at SW 1/4, NW 1/4, NE 1/4, sec. 2, T. 16 N., R. $106 \mathrm{~W}$.

Top of section: eroded

$\begin{array}{cc}\text { Unit } & \text { Stratigraphic } \\ \text { Thickness } & \text { Location } \\ \text { (Meters) } & \text { (Meters) }\end{array}$

2. Sandstone, light-gray, massive, thick- to very thickbedded, cross-stratified, medium-grained; mud pebbles overly erosional base..........

1. Silty claystone, greenishgray to pale-red; interbedded with sandstone, light-gray, flaggy, thin-bedded, ripplestratified, "unstratified," fine-grained..............

Partial thickness of the Wasatch

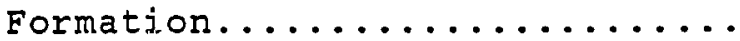

Base of section: overlies light-gray, cross-stratified sandstone of the Wasatch Formation. 
Section G

Section $G$ was measured within the Wasatch Foramtion from SE 1/4, NW 1/4, SW 1/4, sec. 36, T. $17 \mathrm{~N} ., \mathrm{R} .106 \mathrm{~W}$. to SE $1 / 4$, SW 1/4, NW 1/4, sec. 36, T. 17 N., R. 106 W.

Top of section: eroded

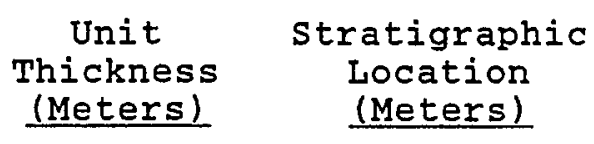

2. Sandstone, light-gray, weathers yellowish-brown, massive, thick- to very thickbedded, cross-stratified, "unstratified," medium-grained; mud pebbles overly erosional base....................

1. Silty claystone and clayey siltstone, light-gray to greenish-gray; interbedded with sandstone, light-gray, flaggy to slabby, thin-bedded, ripplestraified, "unstratified," locally cross-stratified, medium-to very fine-grained.....

Partial thickness of the Wasatch

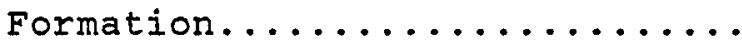
103.2

Base of section: section overlies light-gray, crossstratified sandstone of the Wasatch Formation.

Section $\mathrm{H}$

Section $H$ was measured within the Wasatch Formation from NW 1/4, NW 1/4, NE 1/4, sec. 36, T. $17 \mathrm{~N}, . \mathrm{R} .106 \mathrm{~W}$. to SW 1/4, SW 1/4, SE 1/4, sec. 25, T. 17 N., R. 106 W.

Top of section: eroded 
\begin{tabular}{cc}
$\begin{array}{c}\text { Unit } \\
\text { Thickness }\end{array}$ & Stratigraphic \\
(Meters) & (Meters) \\
\hline
\end{tabular}

2. Sandstone, light-gray, massive, thin- to thick-bedded, cross-stratified, "unstratified," medium-grained; mud pebbles overly erosional

base.......................

$\begin{array}{ll}10.6 & 54.8\end{array}$

1. Silty claystone, greenishgray, locally pale-red;

interbedded with sandstone, light-gray, locally weathers pale-red, flaggy to slabby, thin-bedded, ripple-stratified, "unstratified," medium- to finegrained..................

$54.8 \quad 0.0$

Partial thickness of the Wasatch

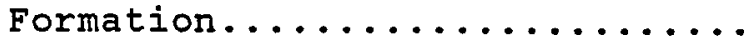

65.4

Base of section: section overlies light-gray, crossstratified sandstone of the Wasatch Formation.

Section $\mathrm{J}$

Section $J$ was measured within the Wasatch Formation from SE 1/4, SE 1/4, SE 1/4, sec. 35, T. $17 \mathrm{~N} ., \mathrm{R} .106 \mathrm{~W}$. to SW 1/4, NE 1/4, SE 1/4, sec. 35, T. 17 N., R. 106 W.

Top of section: eroded

\begin{tabular}{cc}
$\begin{array}{c}\text { Unit } \\
\text { Thickness }\end{array}$ & Stratigraphic \\
(Meters) & (Meterion \\
\hline
\end{tabular}

8. Sandstone, light-gray,

weathers pale-red, massive, thin-to thick-bedded, crossstratified, "unstratified," medium-grained; mud pebble layer overlies erosional base........
3.5
40.8 
7. Silty claystone, greenishgray; interbedded with sandstone, light-gray,

"unstratified," fine-grained....

3.9

36.9

6. Sandstone, light-gray, massive, thin- to thick-bedded, cross-stratified,

"unstratified," medium-grained; mud pebble layer overlies

erosional base.............

6.6

30.3

5. Silty claystone, light-gray.

5.1

25.2

4. Sandstone, light-gray, massive, thick-bedded, crossstratified, "unstratified," medium-grained; mud pebble layer overlies erosional base........

$4.9 \quad 20.3$

3. Silty claystone, greenishgray; interbedded with sandstone, light-gray, "unstratified," burrowed, medium-grained.............

9.5 10.8

2. Sandstone, light-gray, weathers pale-red, flaggy, "unstratified," fine-grained....

0.7

10.1

1. Silty claystone, greenishgray, locally pale-red;

interbedded with sandstone, light-gray, locally weathers pale-red, flaggy, thin-bedded, ripple-stratified, "unstratified," burrowed, fine-

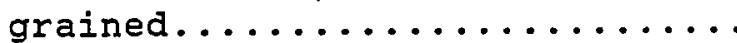

Partial thickness of the Wasatch Formation.................

$10.1 \quad 0.0$

44.3

Base of section: section overlies light-gray sandstone of the Wasatch Formation. 


\section{Section $\mathrm{R}$}

Section $K$ was measured within the Wasatch Formation from NE 1/4, NE 1/4, NE 1/4, sec. 3, T. $16 \mathrm{~N}$, R. $106 \mathrm{~W}$. to NW 1/4, SE 1/4, SE 1/4, sec. 35, T. 17 N., R. 106 W.

Top of section: eroded

\begin{tabular}{cc} 
Unit & Stratigraphic \\
Thickness & Location \\
(Meters) & (Meters) \\
\hline
\end{tabular}

5. Claystone, light-gray to greenish-gray; interbedded with sandstone, light-gray, thinbedded, ripple-stratified, "unstratified," fine- to very fine-grained..............

4. Sandstone, light-gray, weathers moderate-red, slabby, "unstratified," fine-grained....

3. Silty claystone, light-gray to greenish-gray, locally palered; interbedded with sandstone, light-gray, locally weathers pale-red, flaggy to slabby, thin-bedded, ripple-stratified, "unstratified," medium- to finegrained..................

2. Sandstone, light-gray, massive, thick-bedded, crossstratified, "unstratified," medium-grained; west-dipping second order contacts, mud pebble layer overlies erosional base...................

1. Sandstone, light olive-gray, thin-to very thin-bedded, "unstratified," fine- to very fine-grained; gradational base.. 
Partial thickness of the Wasatch

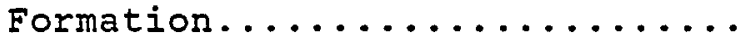

25.2

Base of section: section overlies greenish-gray silty claystone of the Wasatch Formation.

Section $L$

Section $L$ was measured within the Wasatch Formation from SW 1/4, SW 1/4, SE 1/4, sec. 35, T. 17 N., R. $106 \mathrm{~W}$. to NW $1 / 4$, SW $1 / 4$, NE 1/4, sec. 35, T. 17 N., R. $106 \mathrm{~W}$.

Top of section: eroded

\begin{tabular}{cc}
$\begin{array}{c}\text { Unit } \\
\text { Thickness }\end{array}$ & Stratigraphic \\
Location \\
(Meters) & (Meters) \\
\hline
\end{tabular}

7. Sandstone, light-gray, weathers moderate-red, slabby, thin-bedded, ripple-stratified, "unstratified," locally crossstratified, fine- to very finegrained; gradational base......
3.0
40.6

6. Silty claystone, light brownish-gray to greenish-gray; interbedded with sandstone, light-gray, weathers moderate red, flaggy, "unstratified," burrowed, medium- to finegrained.................

5. Sandstone, light-gray, weathers dark-reddish-brown, massive, thick-bedded, crossstratified, "unstratified," medium-grained; mud pebble layer above erosional base..........

4. Silty claystone, lightbrownish-gray............. 
3. Sandstone, light-gray, weathers reddish-brown, massive, thick-bedded, cross-stratified, medium-grained; mud pebble layer overlies erosional base........

$10.9 \quad 9.4$

2. Silty claystone, greenishgray .................. $1.5 \quad 7.9$

1. Sandstone, light-gray, massive, thin- to thick-bedded, cross-stratified, mediumgrained; mud pebble layer overlies erosional base........

$\begin{array}{ll}7.9 & 0.0\end{array}$

Partial thickness of the Wasatch Formation................

Base of section: section overlies greenish-gray silty claystone of the wasatch Formation.

Section $M$

Section $M$ was measured within the Wasatch Formation at SW 1/4, NW 1/4, SE 1/4, sec. 35, T. 17 N., R. 106 W.

Top of section: eroded

$\begin{array}{cc}\text { Unit } & \text { Stratigraphic } \\ \text { Thickness } & \text { Location } \\ \text { (Meters) } & \text { (Meters) }\end{array}$

5. Sandstone, light-gray, massive, thick-bedded, crossstratified, "unstratified," medium-grained; mud pebble layer overlies erosional base.........

6.0

20.6

4. Sandstone, light-gray, weathers moderate-red, slabby, thin-bedded, ripple-stratified, sharp to gradational base, fineto very fine-grained..........

3. Silty claystone, greenishgray.................. 
2. Sandstone, light-gray, weathers moderate-red, slabby, "unstratified," sharp base,

fine-grained..............

1.8

13.3

1. Silty claystone to clayey

siltstone, light-gray to

greenish-gray, locally moderate

red; interbedded with sandstone,

light-gray, weathers moderate-

red, thin-beoded, ripple-

stratified, "linstratified,"

medium- to very fine-grained....

13.3

0.0

Partial thickness of the Wasatch

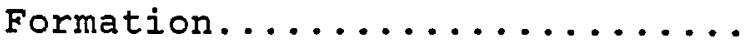

26.6

Base of section: section overlies light-gray silty claystone of the Wasatch Formation.

Section $\mathrm{N}$

Section $N$ was measured within the Wasatch Formation from NW 1/4, SE 1/4, SW 1/4, sec. 35, T. $17 \mathrm{~N}$, , R. $106 \mathrm{~W}$. to NW 1/4, NE 1/4, SW 1/4, sec. 35, T. 17 N., R. 106 W.

Top of section: eroded

\begin{tabular}{cc}
$\begin{array}{c}\text { Unit } \\
\text { Thickness } \\
\text { (Meters) }\end{array}$ & $\begin{array}{c}\text { Stratigraphic } \\
\text { Location } \\
\text { (Meters) }\end{array}$ \\
\hline
\end{tabular}

10. Sandstone, light-gray, weathers moderate-red, massive, thick-bedded, cross-stratified, "unstratified," medium-grained; mud pebble layer overlies erosional base.............

76.4 
9. Sandstone, light-gray, weathers moderate-red, massive, thick- to very thick-bedded, cross-stratified,

"unstratified," medium-grained; mud pebble layer overlies erosional base..............

8. Silty claystone, greenishgray...................

7. Sandstone, light-gray, slabby, thin-bedded, ripplestratified, gradational base, fine- to very fine-grained......

6. Claystone, light-gray to greenish-gray, locally

carbonaceous...............

5. Sandstone, pale-yellowishorange, flaggy, "unstratified," medium-grained.............

4. Silty claystone, light-gray to greenish-gray, locally carbonaceous; interbedded with sandstone, light-gray, weathers pale-red, ripple-stratified, "unstratified," medium- to fine-

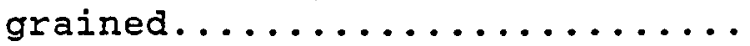

3. Sandstone, light-gray, weathers moderate-red, massive, thick-bedded, cross-stratified, "unstratified," east-dipping second order contacts, mediumgrained; mud pebble layer overlies erosional base........

2. Silty claystone, light-gray to greenish-gray; interbedded with sandstone, light-gray, weathers pale-red, thin-bedded, ripple-stratified, "unstratified," locally crossstratified, burrowed, medium- to fine-grained.............. 
1. Sandstone, light-gray, weathers moderate-red,

"unstratified," fine-grained...

$1.9 \quad 0.0$

Partial thickness of the Wasatch

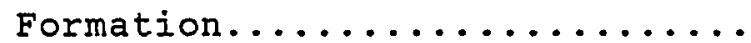

81.1

Base of section: section overlies light-gray silty claystone of the Wasatch Formation.

Section 0

Section $O$ was measured within the Wasatch Formation at NW 1/4, NE 1/4, SW 1/4, sec.35, T. 17 N., R. 106 W.

Top of section: overlain by silty claystone of the wasatch Formation.

$\begin{array}{cc}\text { Unit } & \text { Stratigraphic } \\ \text { Thickness } & \text { Location } \\ \text { (Meters) } & \text { (Meters) }\end{array}$

3. Sandstone, light-gray, weathers moderate-red, massive, thick- to very thick-bedded, cross-stratified, "unstratified," medium-grained; mud pebble layers overly erosional base..............

2. Coal, black, carbonaceous; interbedded with shale, moderate-brown, carbonaceous.... 0.5 2.7

1. Sandstone, yellowish-gray, "unstratified," medium-grained.. 2.7 0.0

Partial thickness of the Wasatch 12.1

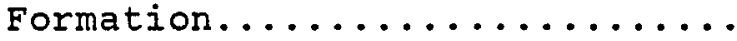

Base of section: section overlies locally carbonaceous, light-gray claystone of the Wasatch Formation. 
Section $P$

Section $P$ was measured within the Wasatch Formation from SW 1/4, NW 1/4, SW 1/4, sec. 35, T. $17 \mathrm{~N} ., \mathrm{R}$. $106 \mathrm{~W}$. to $\mathrm{SE} 1 / 4, \mathrm{NE} 1 / 4, \mathrm{SE} 1 / 4, \mathrm{sec}, 34, \mathrm{~T} .17 \mathrm{~N}, \mathrm{R}, 106 \mathrm{~W}$.

Top of section: eroded

\begin{tabular}{cc} 
Unit & Stratigraphic \\
Thickness & Location \\
(Meters) & (Meters) \\
\hline
\end{tabular}

5. Sandstone, light-gray, weathers moderate-red, massive, thin- to thick-bedded, crossstratified, medium-grained; mud pebble layer overlies erosional

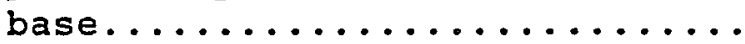

$6.4 \quad 36.1$

4. Silty claystone, greenishgray, locally pale-red; interbedded with sandstone, light-gray, weathers moderatered, slabby, ripple-stratified, "unstratified," locally crossstratified, burrowed, medium- to very fine-grained............

$16.4 \quad 19.7$

3. Sandstone, light-gray, massive, thick-bedded, crossstratified, "unstratified," west-dipping second order contacts, medium-grained; mud pebble layer overlies erosional base....................

$6.5 \quad 13.2$

2. Silty claystone, greenishgray, locally pale-red; interbedded with sandstone, light-gray, weathers pale-red, thin-bedded, ripple-stratified, "unstratified," fine- to very

fine-grained.............. 
1. Sandstone, light-gray, slabby, thin-bedded, ripplestratified, fine-grained; sharp

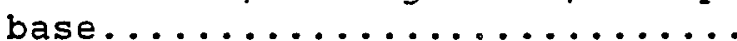

$3.4 \quad 0.0$

Partial thickness of the Wasatch

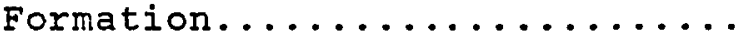

42.5

Base of section: section overlies interbedded claystone, coal and sandstone of the Wasatch Formation.

Section $Q$

Section $Q$ was measured within the Wasatch Formation from NW 1/4, SW 1/4, SE 1/4, sec. 34, T. 17 N., R. $106 \mathrm{~W}$. to SE 1/4, NE 1/4, SW 1/4, sec. 34, T. 17 N., R. 106 W.

Top of section: section overlain by ostracode coquina of the Luman Tongue of the Green RIver Formation.

$\begin{array}{cc}\text { Unit } & \text { Stratigraphic } \\ \text { Thickness } & \text { Location } \\ \text { (Meters) } & \text { (Meters) }\end{array}$

3. Silty claystone, greenishgray, locally carbonaceous: interbedded with sandstone, light-gray, thin-bedded, ripplestratified, "unstratified,"

fine-grained...............
6.9
9.3

2. Sandstone, light-gray, thinbedded, ripple-stratified, burrowed, medium-grained........

0.7

8.6

1. Claystone, light-gray;

interbedded with sandstone,

light-gray, thin-bedded, ripplestratified, burrowed, fine-

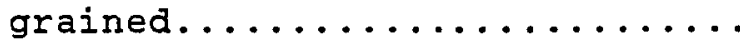

$8.6 \quad 0.0$

Partial thickness of the Wasatch

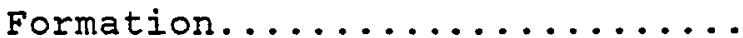


Base of section: section overlies light olive-gray silty claystone of the Wasatch Formation. 


\section{PLEASE NOTE:}

Oversize maps and charts are filmed in sections in the following manner:

\section{LEFT TO RIGHT, TOP TO BOTTOM, WITH SMALL OVERLAPS}

The following map or chart has been refilmed in its entirety at the end of this dissertation (not available on microfiche). A xerographic reproduction has been provided for paper copies and is inserted into the inside of the back cover.

Black and white photographic prints (17" x 23") are available for an additional charge.

\section{University Microfilms International}


FIELD AREA I

Wasatch Formation

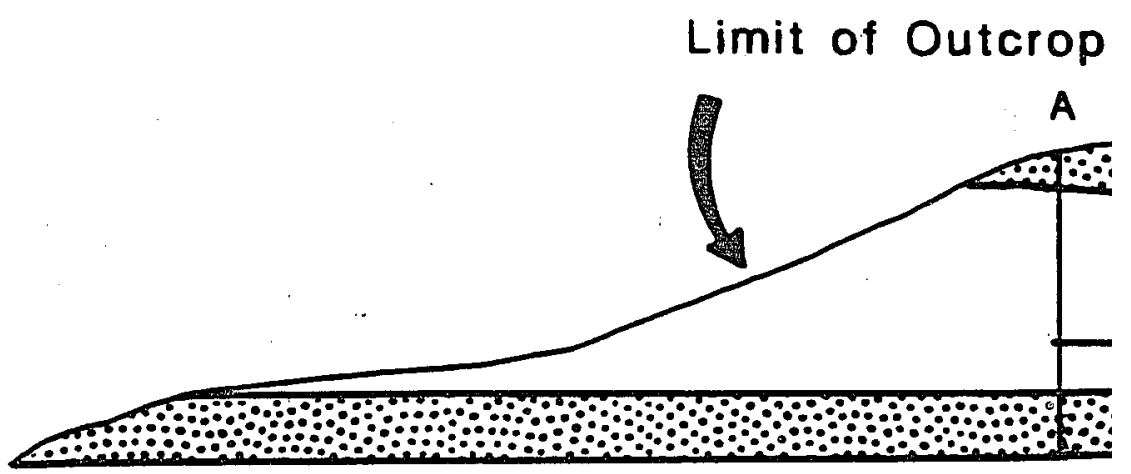

Fort Union Formation 
mit of Outcrop.

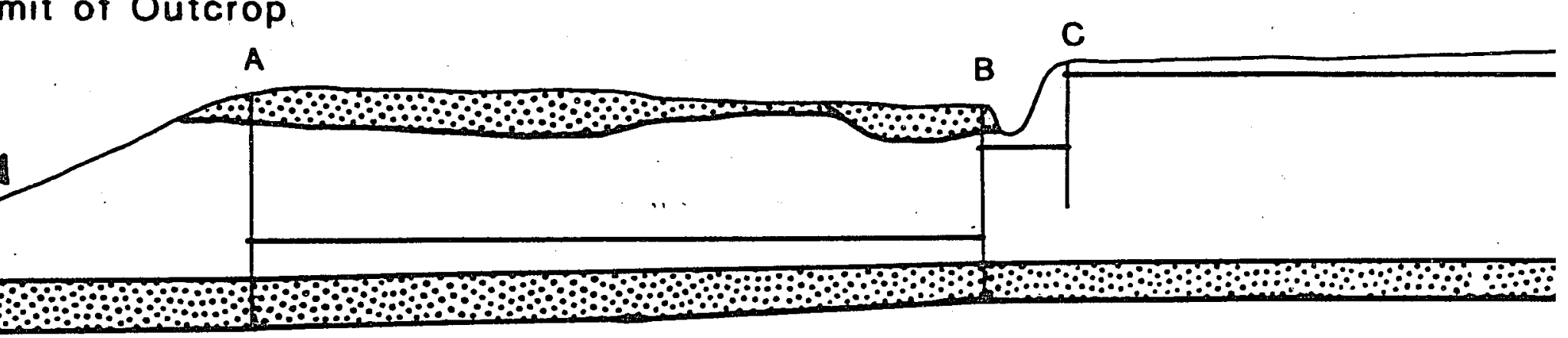




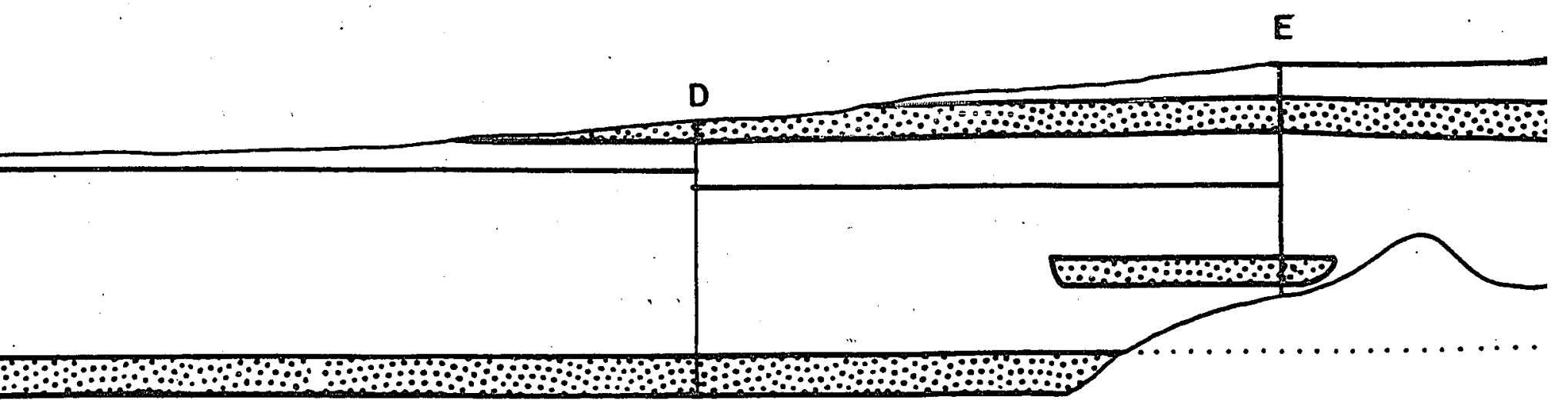




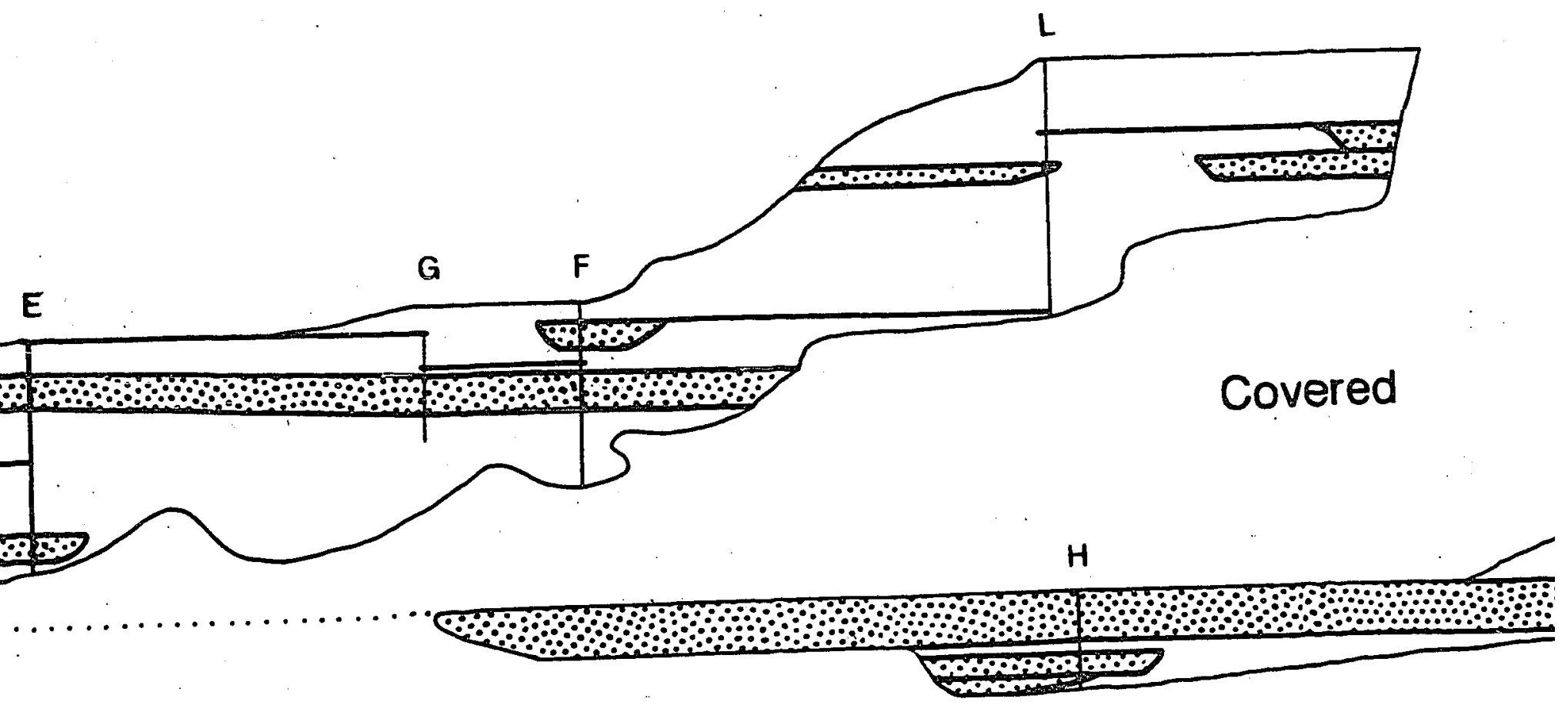




\section{$<$

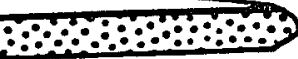
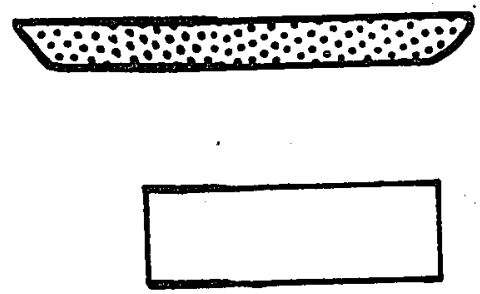

B

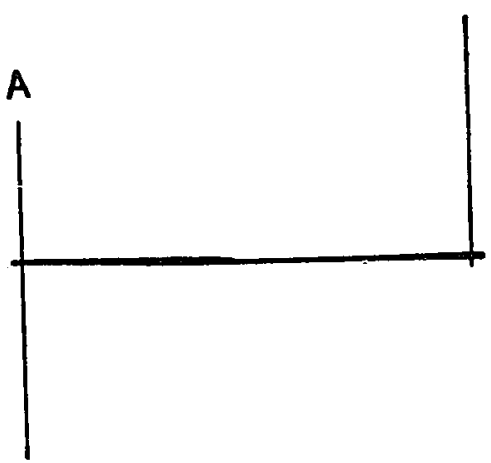

Luman Tongue of the Green 


\section{Explanation}

$50 \mathrm{~m}$

7.78



$50 \mathrm{~m}$
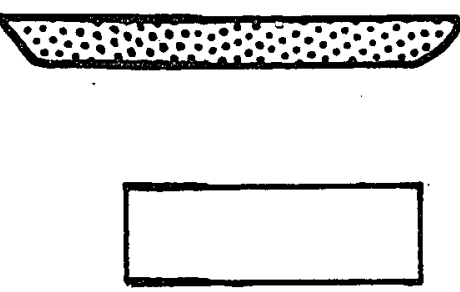

B

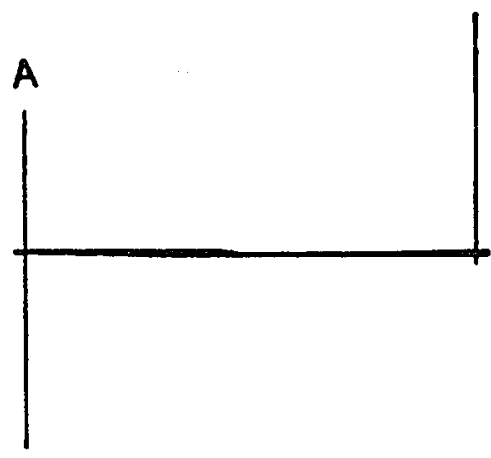

Measured Sections with Correlations

Correlations (covered)

Channe! Sandstones

Overbank Deposits

Scale 1:2000

Luman Tongue of the Green River Formation 


\section{FIELD AREA II}

Q

K

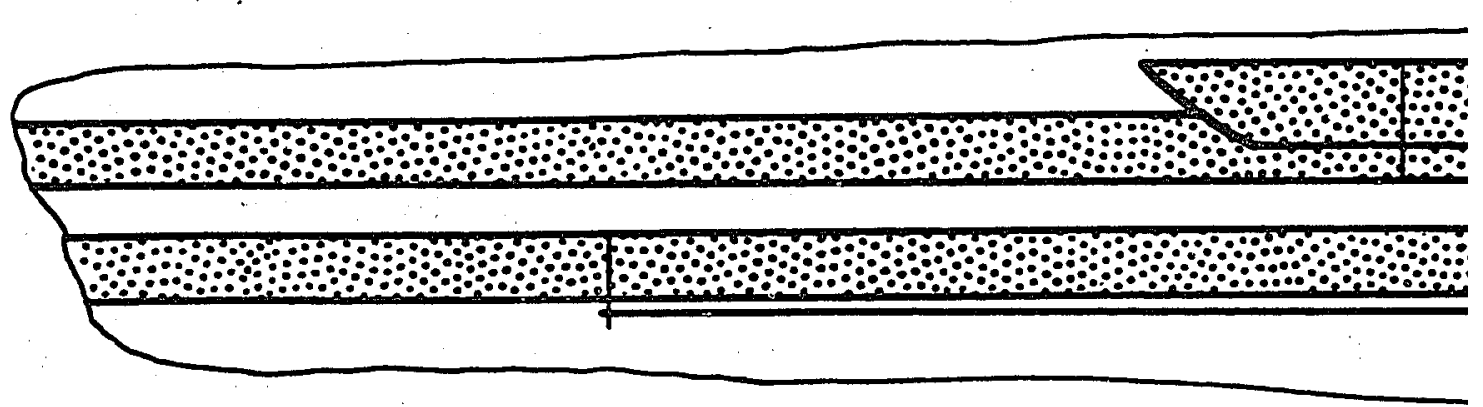

E

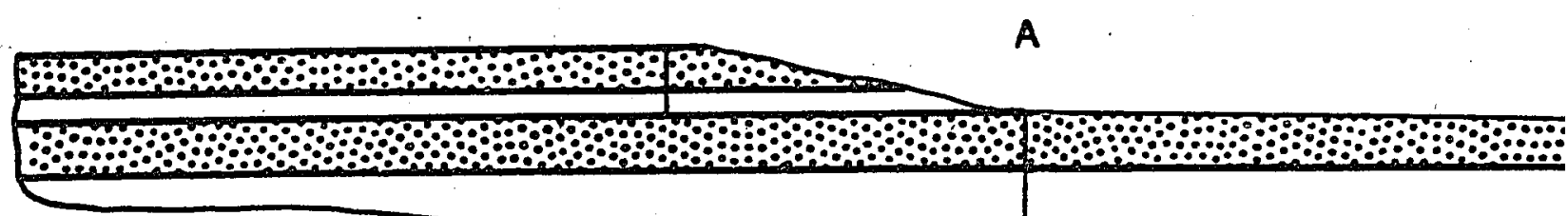




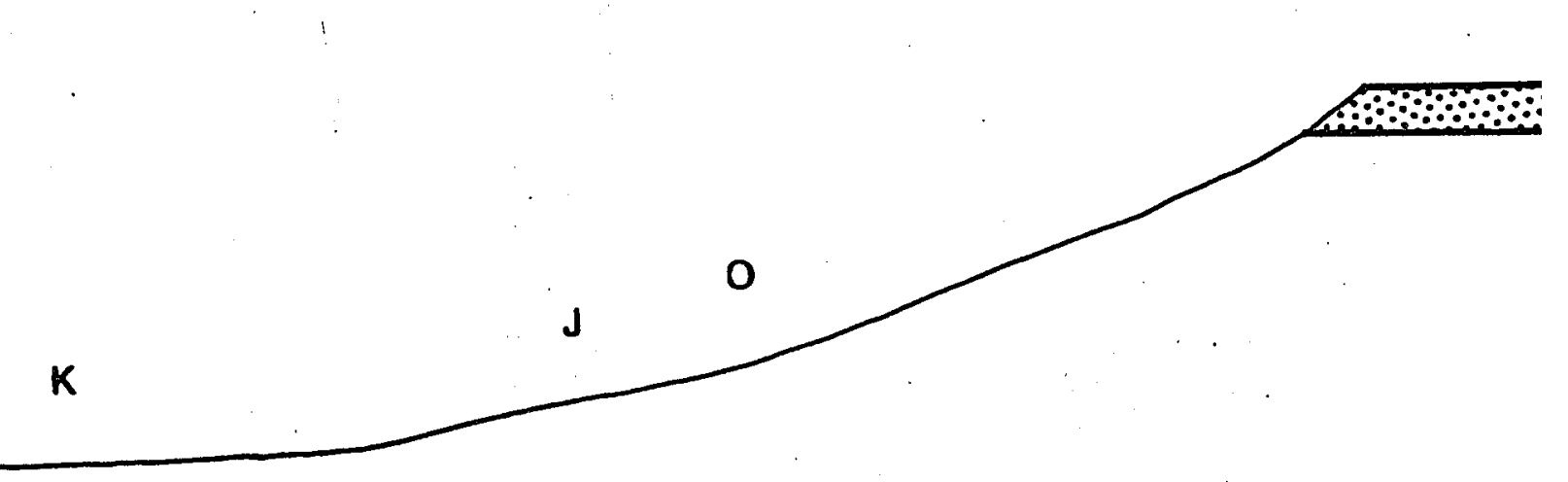

mom OHo

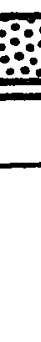

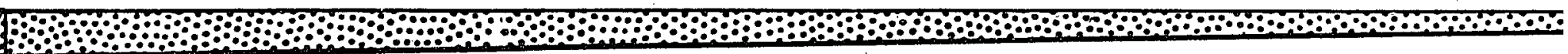

Covered

\section{A}

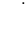




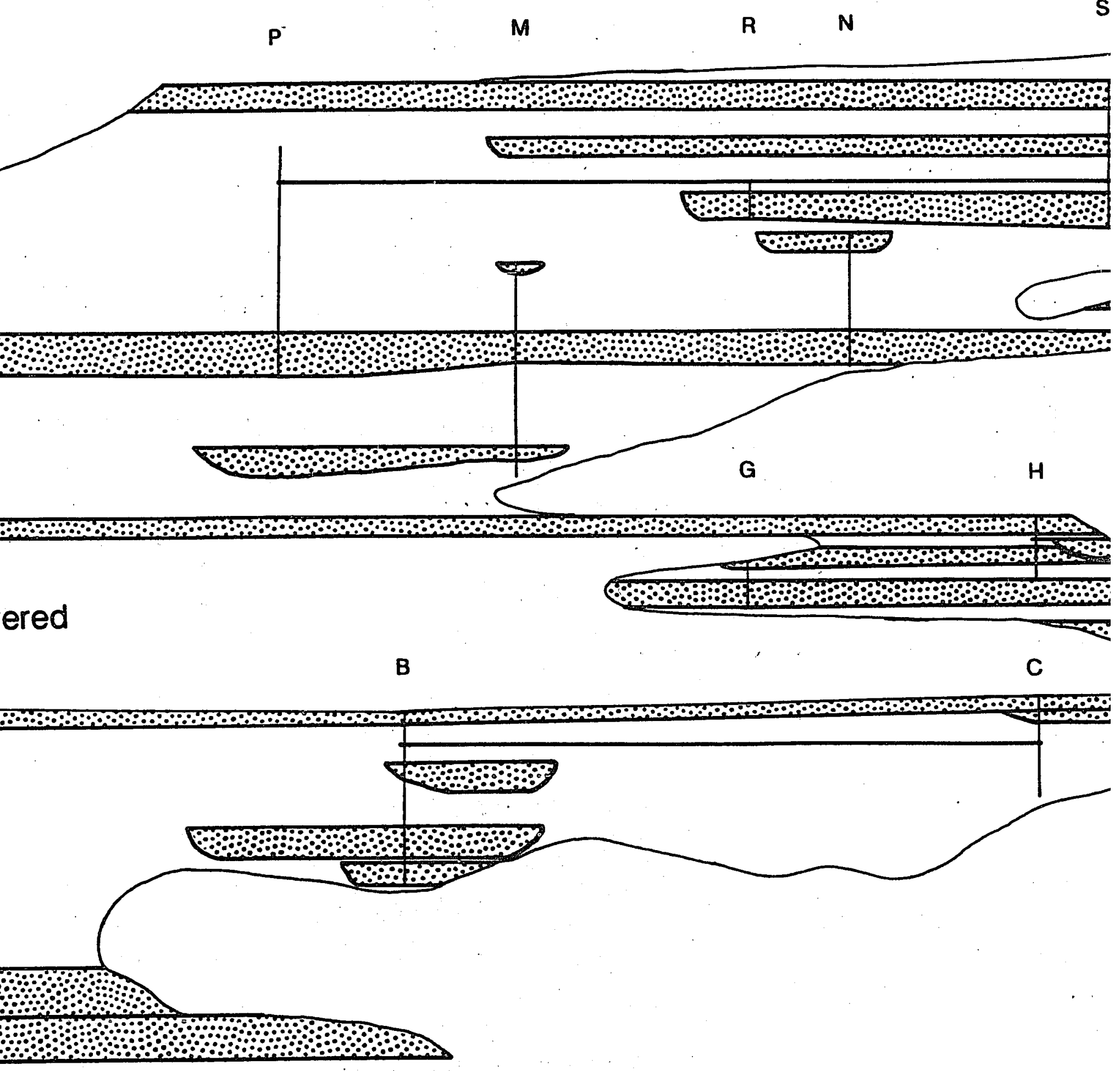


CC

U: $\quad$ v

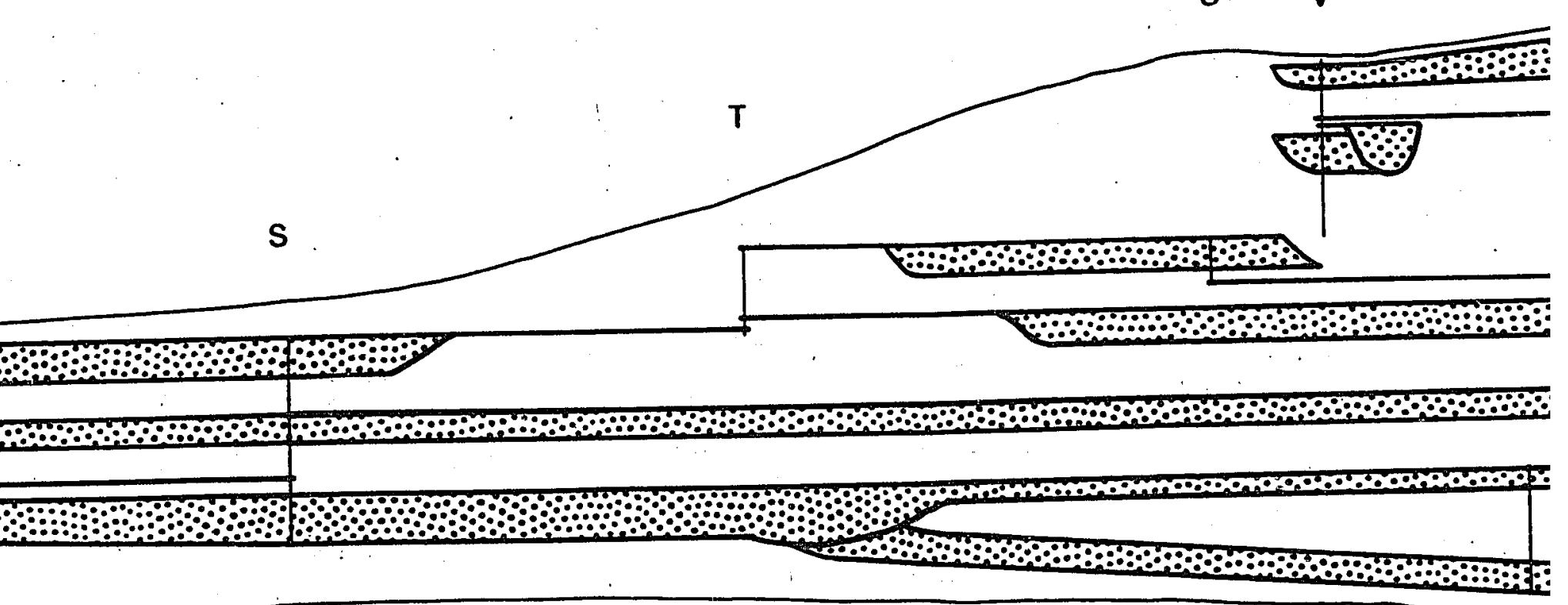

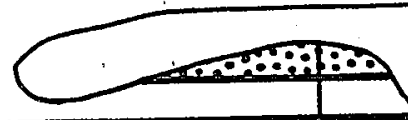

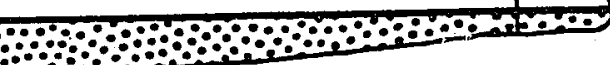

EE

EE

Covered

$H$

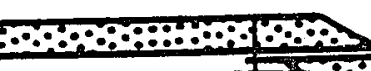

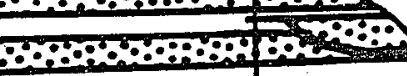

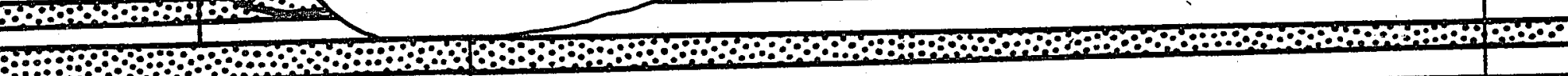

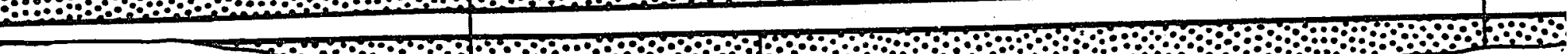

C

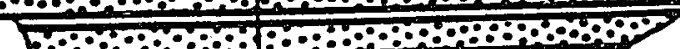

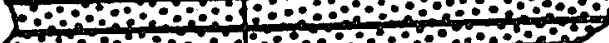


Luman Tongue of the Green Rive

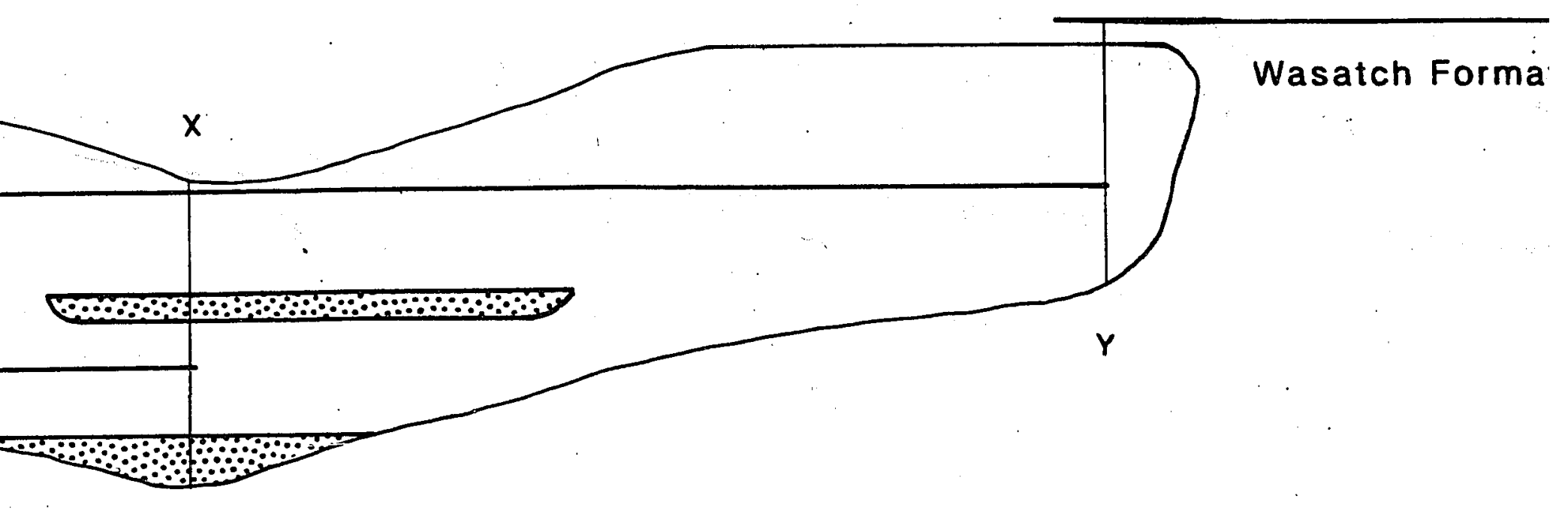




\section{PLEASE NOTE:}

Oversize maps and charts are filmed in sections in the following manner:

\section{LEFT TO RIGHT, TOP TO BOTTOM, WTH SMALL OVERLAPS}

The following map or chart has been refilmed in its entirety at the end of this dissertation

(not available on microfiche). A xerographic reproduction has been provided for paper copies and is inserted into the inside of the back cover.

Black and white photographic prints (17" x 23") are available for an additional charge.

\section{University Microfilms International}


FIELD AREA III

Luman Tongue of the Green River Formation

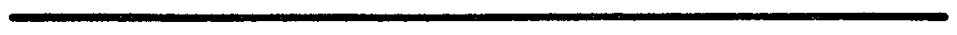

Wasatch Formation

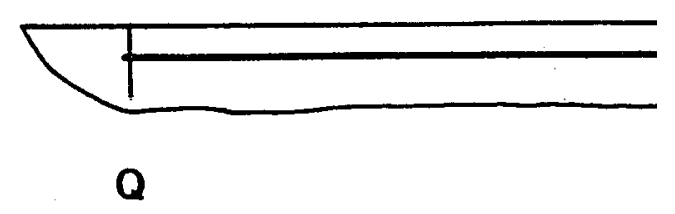




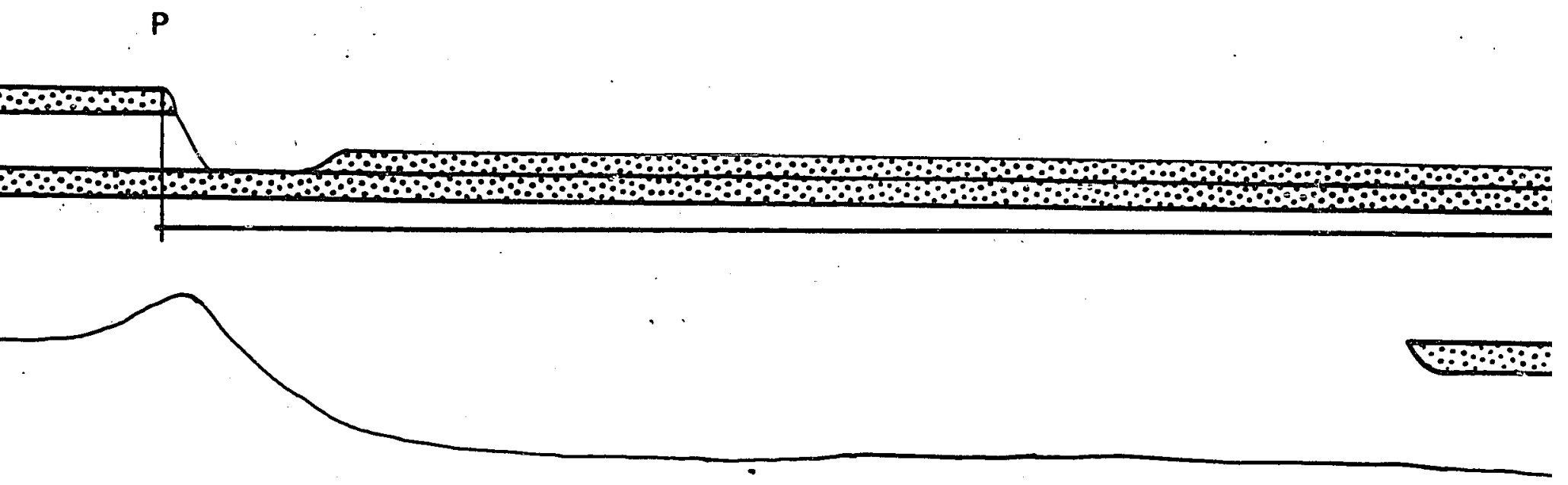


N $O$

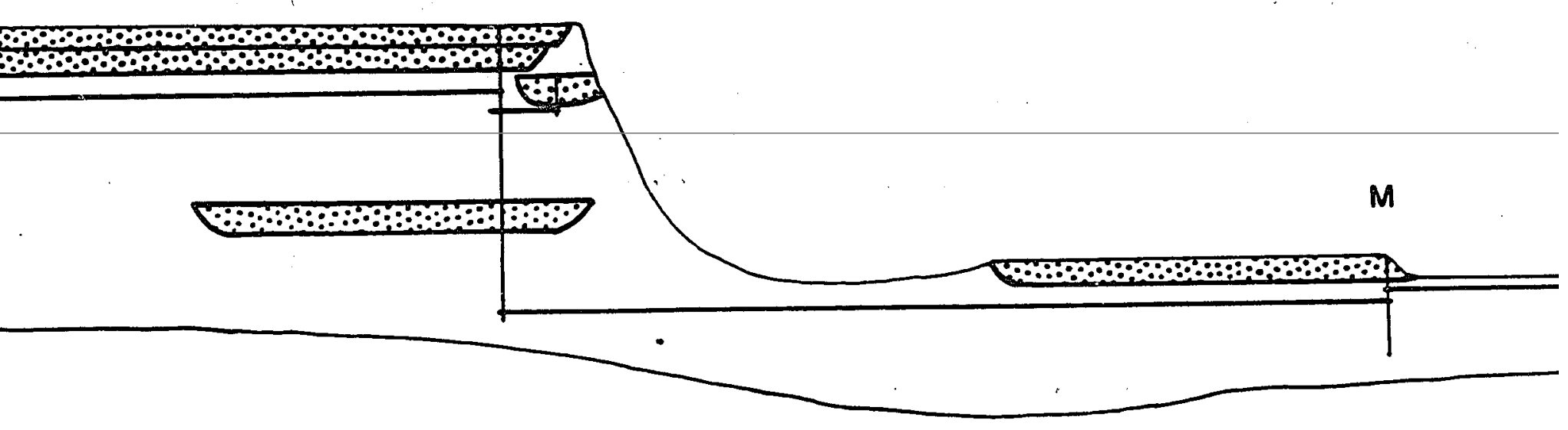




1


L 
K

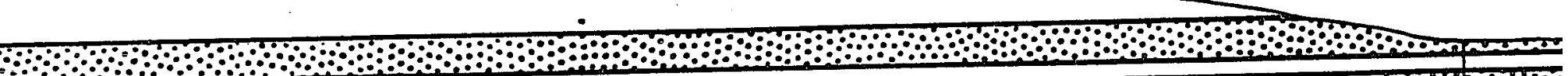

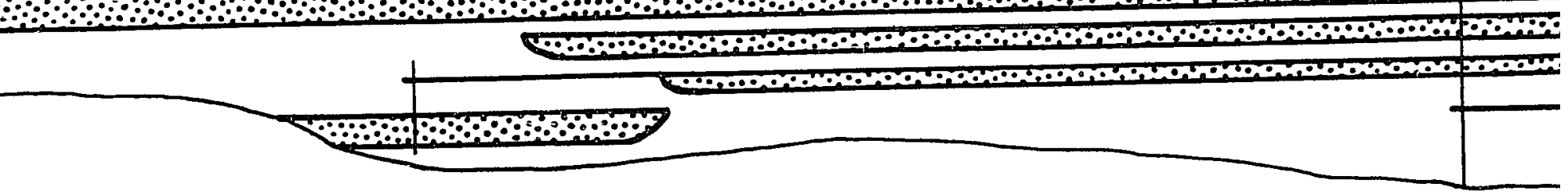



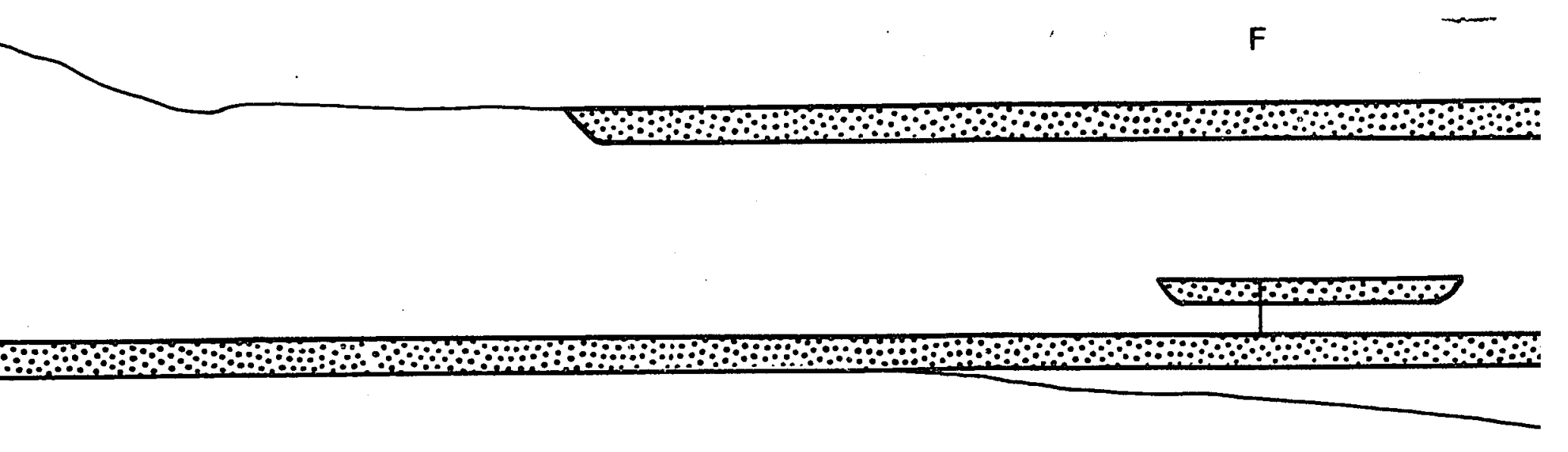


\section{PLATE II}

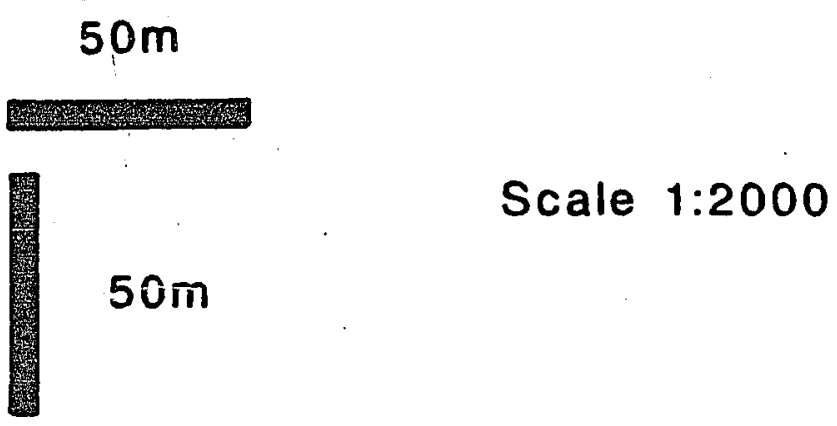

H

E

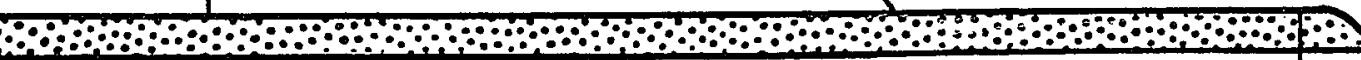

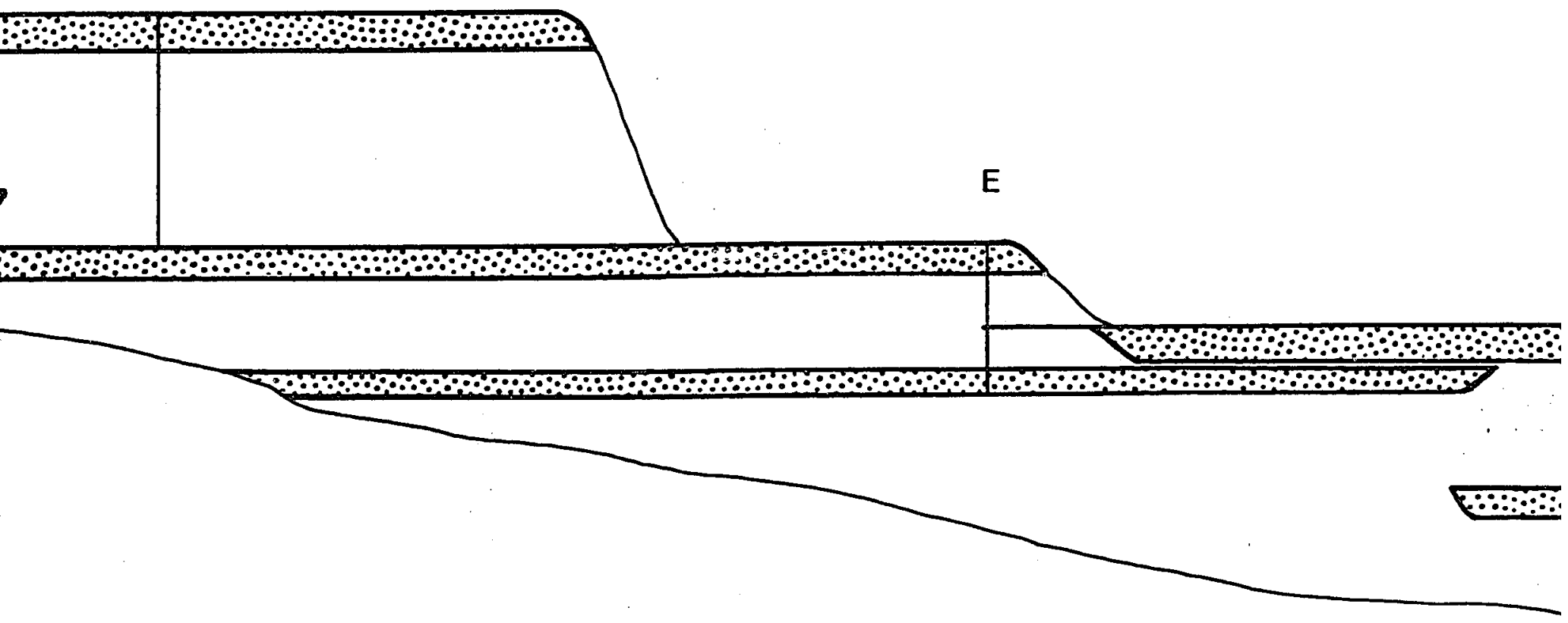




\section{Explanation}

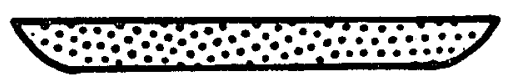
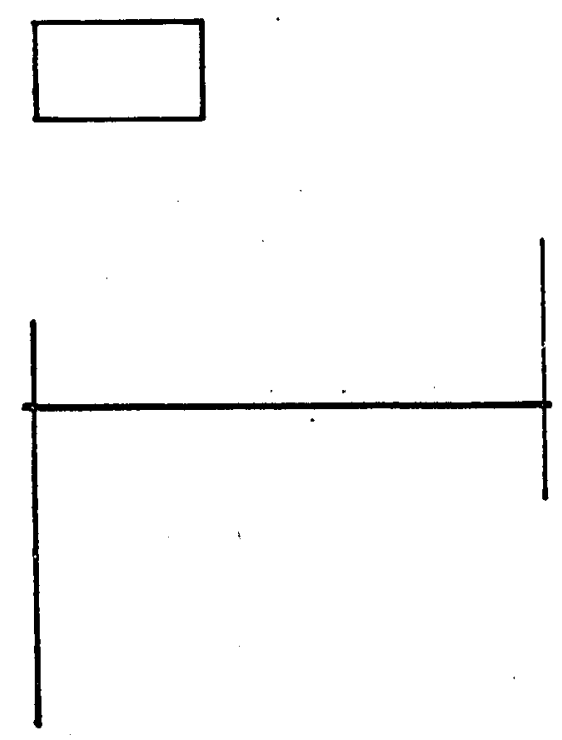

.................
Channel Sandstones

Overbank Deposits

Measured Sections with Correlations

Correlations (covered)

C B

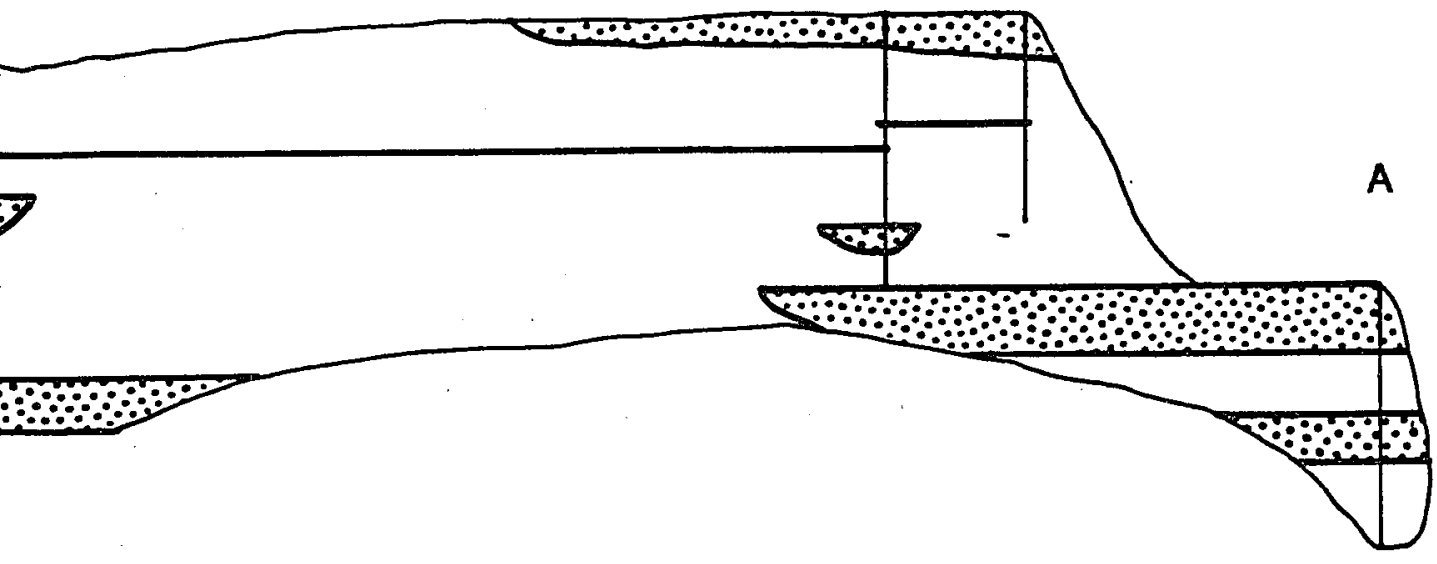

Wasatch Formatic 


\section{FIELD AREA IV}

(modified from Kirschbaum, 1987)

Wasatch Formation

Fort Union Formation
11

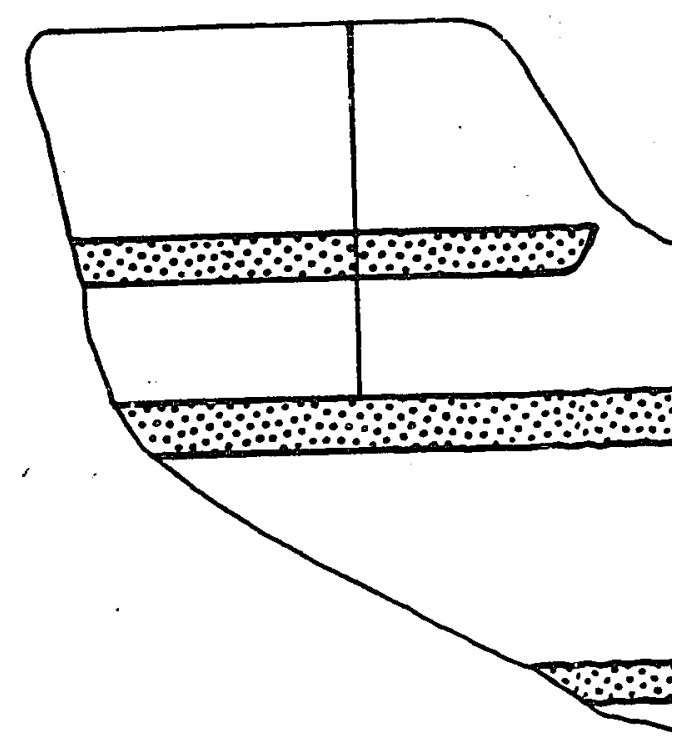




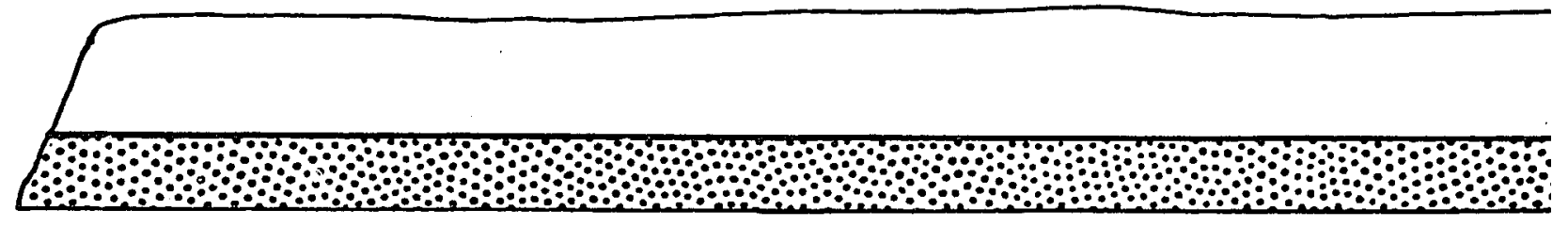

\section{1}




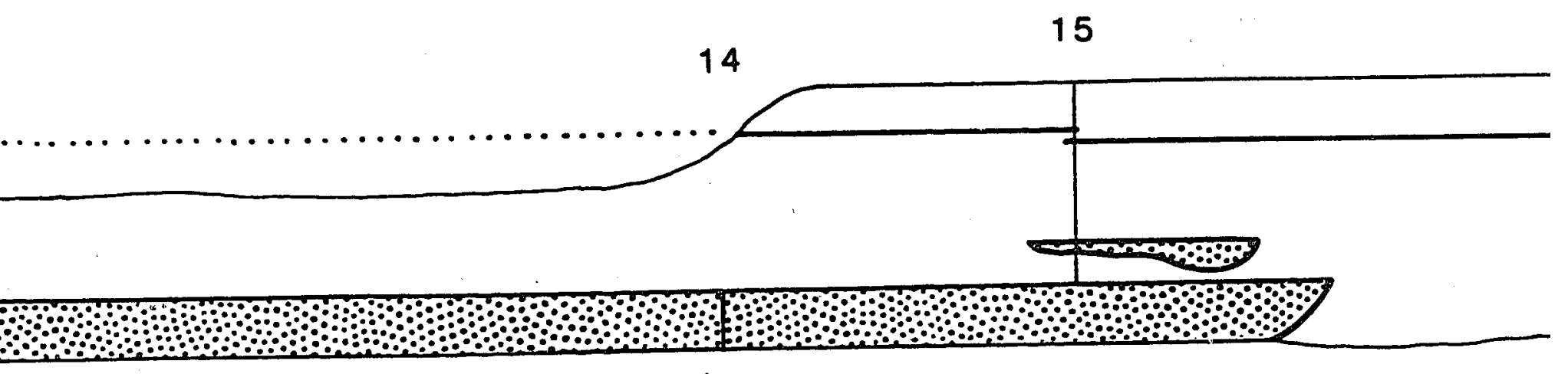


$16 \quad 17$

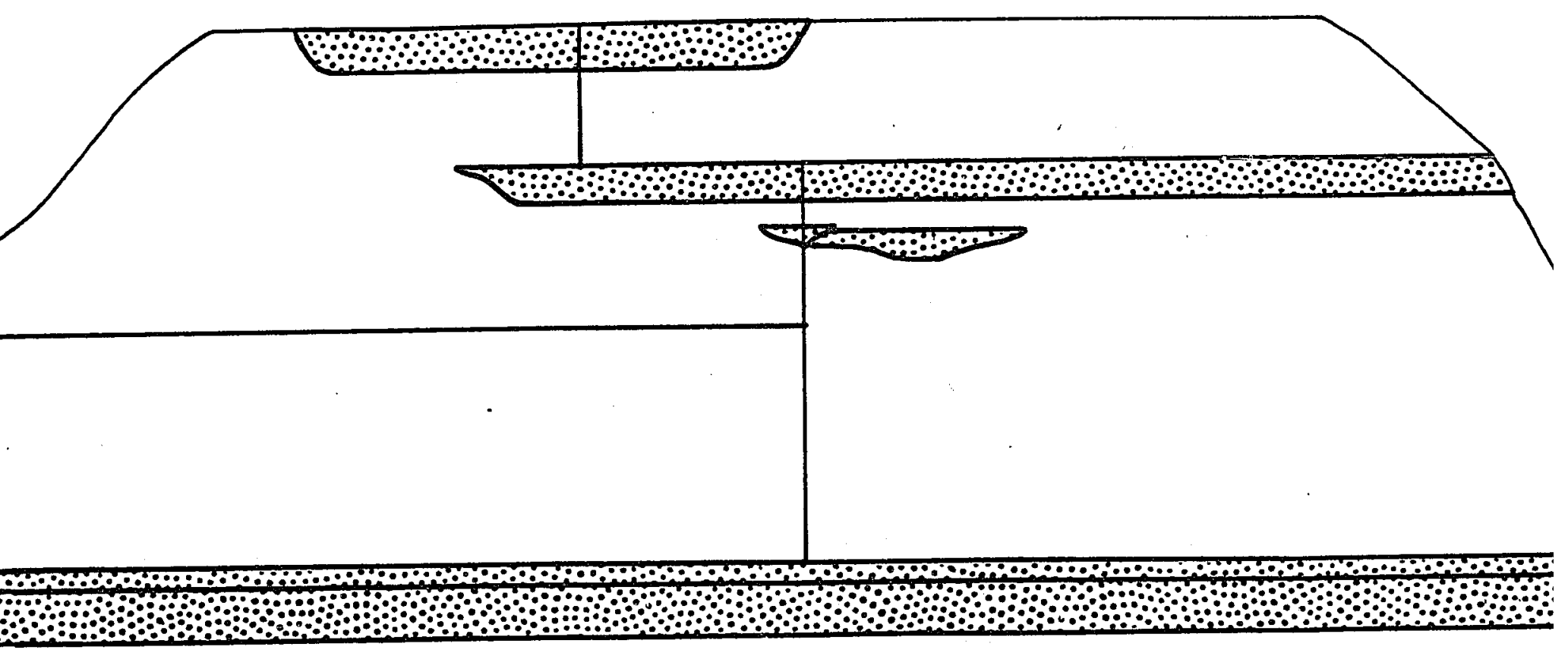




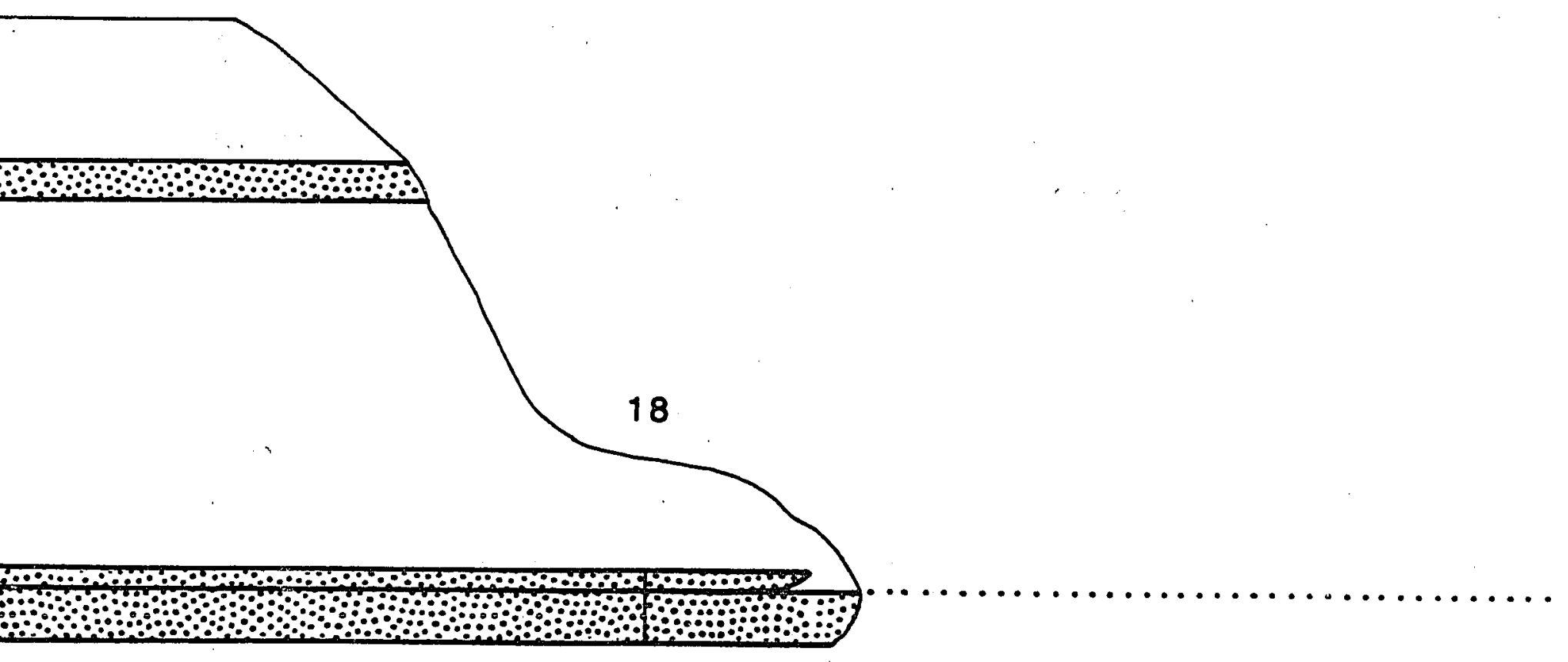


19

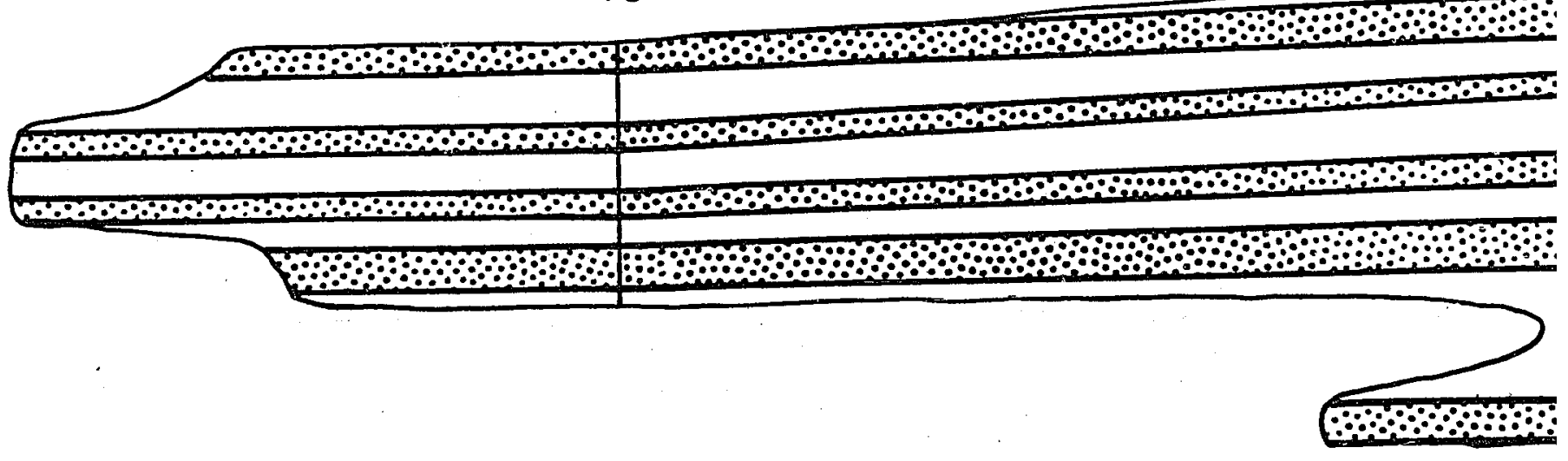




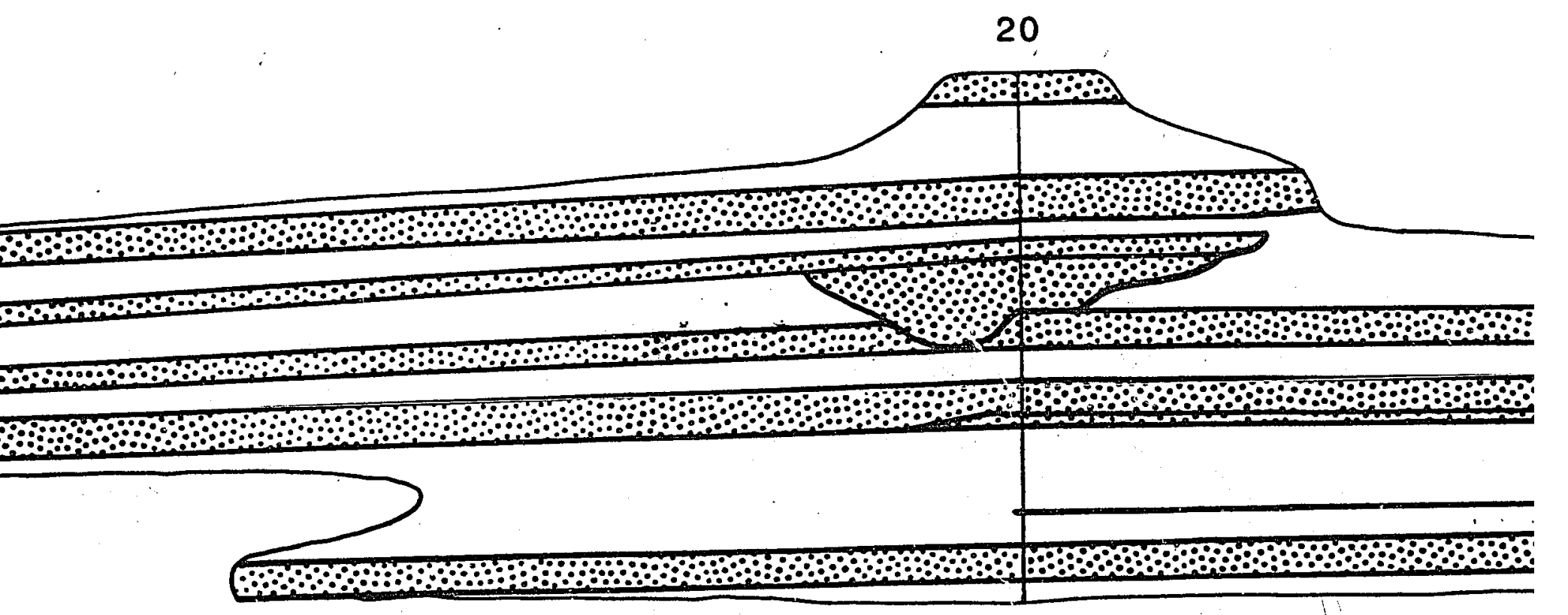




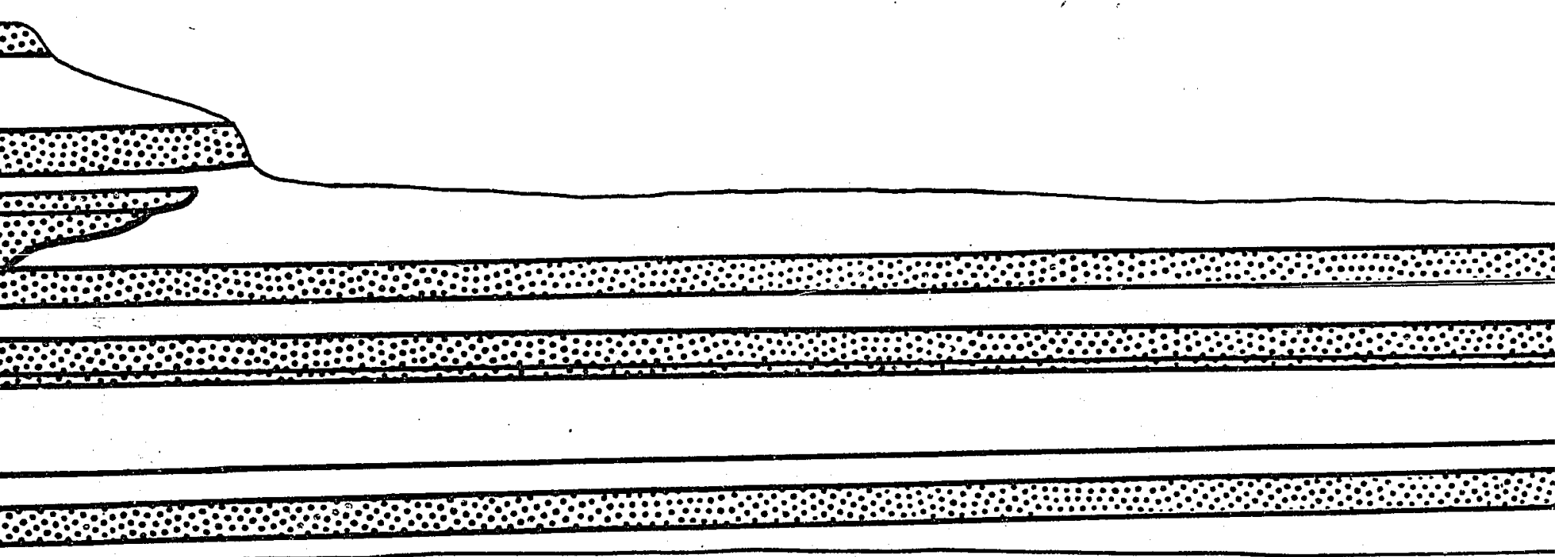




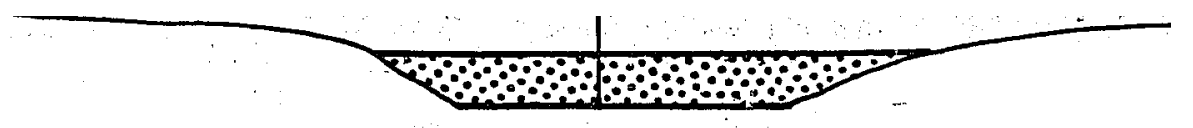

21

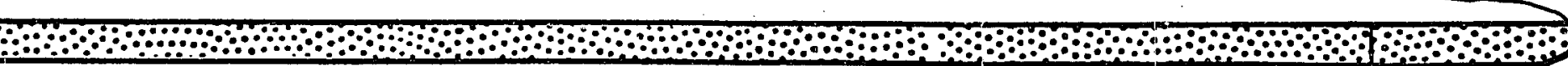

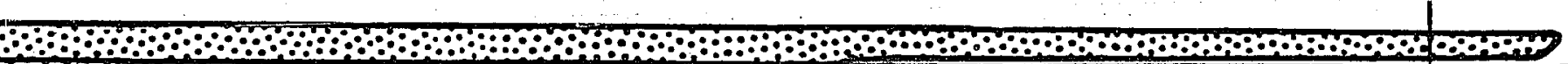
OHa 
Fort Union Formation

\section{FIELD AREA II}

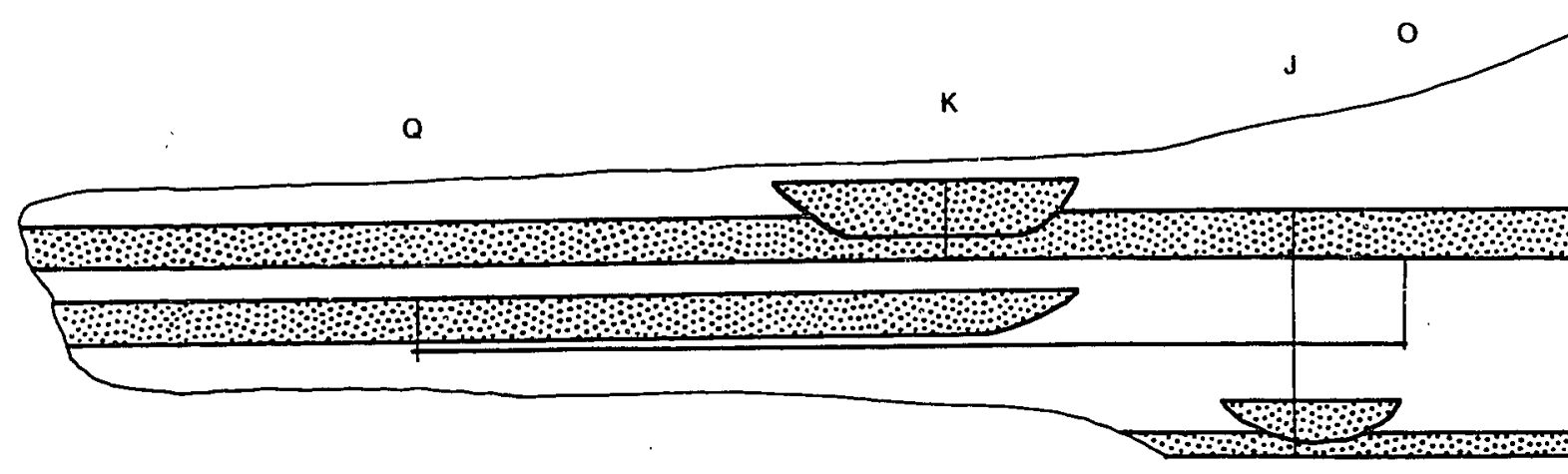

E

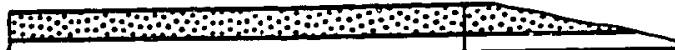

A

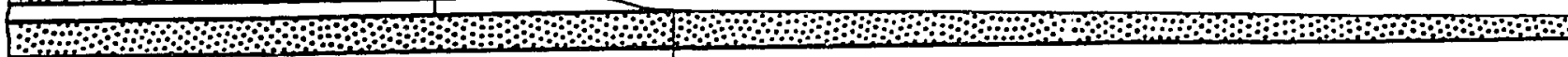


Luman Tongue of the Green River Formation

Wasatch Formation

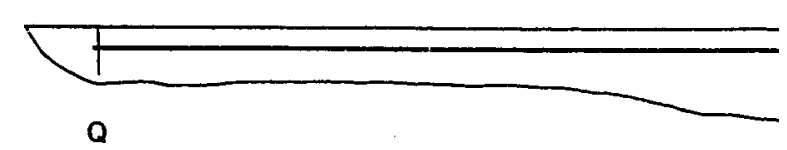

Q

\section{FIELD AREA IV}

(modified from Kirschbaum, 1987)

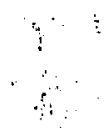

Wasatch Formation
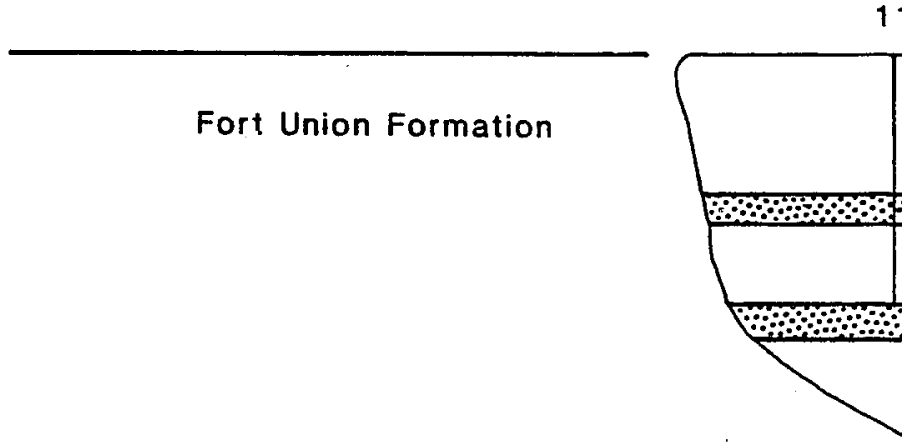


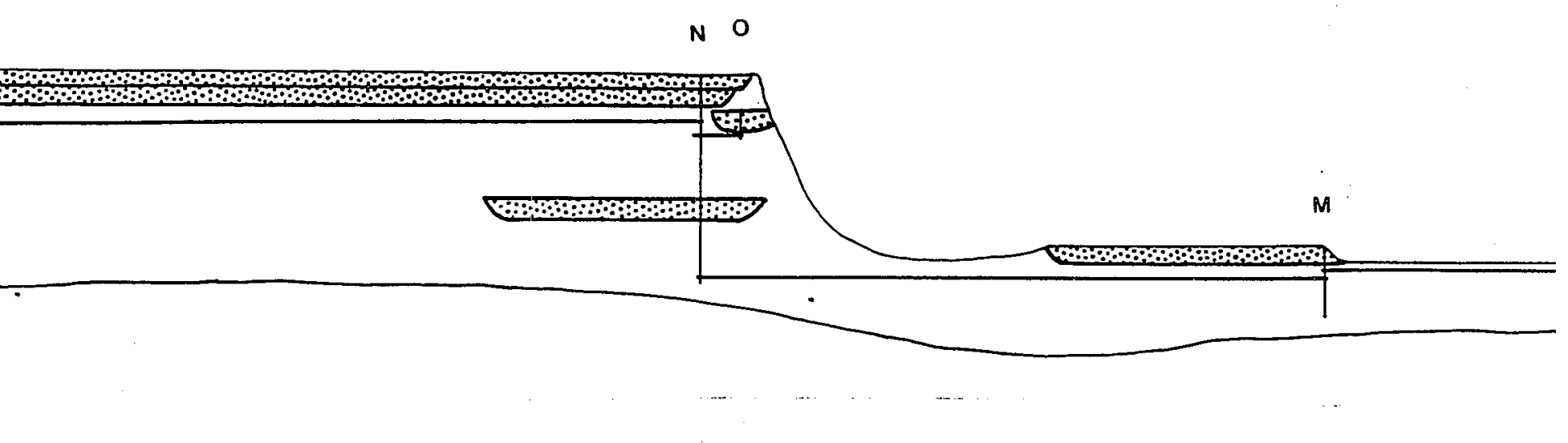

...

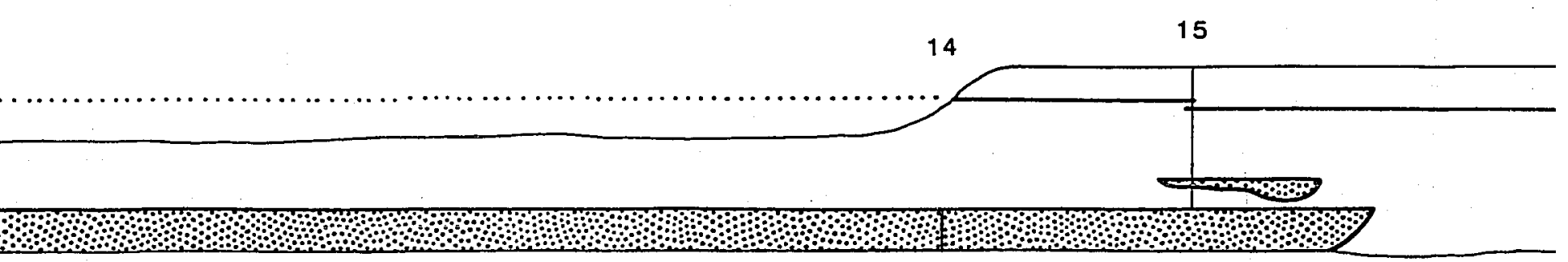


K

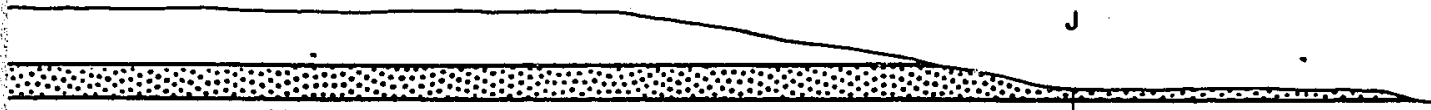

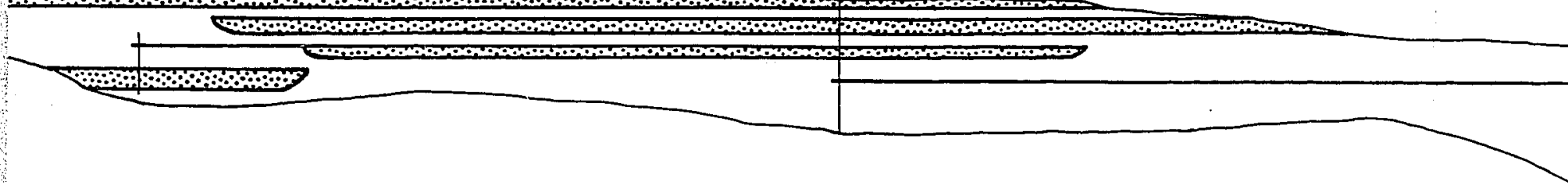

Limi 
G

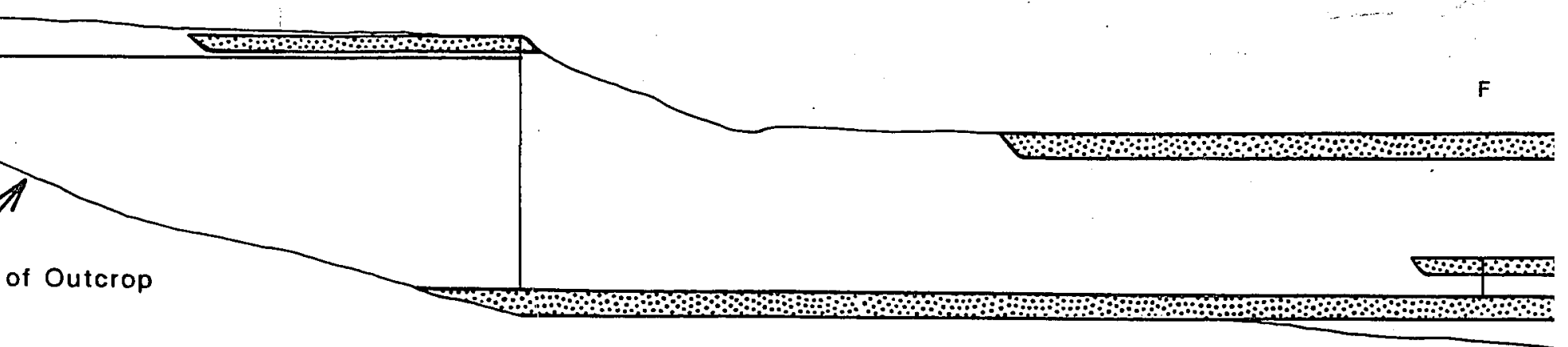

20

19



(1)

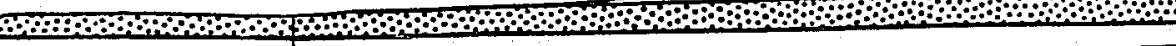
For

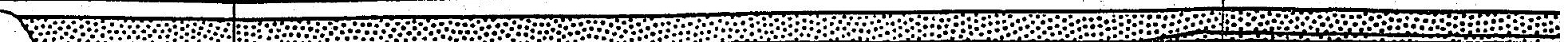


